\title{
QUALIDADE DE VIDA E POLÍTICAS PÚBLICAS NO MUNICÍPIO DE FEIRA DE SANTANA - BAHIA
}

\section{CREUZA MARIA BRITO QUEIROZ}

Tese de Doutorado apresentada ao Departamento de Prática de Saúde da Faculdade de Saúde Pública da Universidade de São Paulo para obtenção do Grau de Doutor em Saúde Pública.

Área de Concentração: Serviços em Saúde Pública.

Orientadora: Prof ${ }^{\mathrm{a}}$ Dr $^{\mathrm{a}}$ EVELIN NAKED DE CASTRO SÁ

São Paulo

2002 
Ficha Catalográfica - Biblioteca Central Julieta Carteado

\section{Queiroz, Creuza Maria Brito}

Q 43q Qualidade de vida e políticas públicas no município de Feira de Santana-Ba.

1 Creuza Maria Brito Queiroz - Feira de Santana-Ba: (s.n.), 2002.

p. : il

Orientador: Evelyn Naked de Castro Sá

Tese (Doutorado em Saúde Pública) - faculdade de Saúde Pública da Universidade de São Paulo.

Bibliografia

1. Qualidade de vida - Feira de Santana. 2. Políticas públicas - Feira de Santana. I. Sá, Evelyn Naked de Castro. II. Título.

CDU: 614:17.023.35

Autorizo, exclusivamente para fins acadêmicos e científicos, a reprodução total ou parcial desta tese, por processos fotocopiadores.

Assinatura:

Data: 
DEDICATÓRIA

À Carlos Romeu, Marcelo, Vítor e André, maiores relíquias da minha vida.

À todas as pessoas que têm a qualidade de vida limitada pelas injustiças sociais. 


\section{AGRADECIMENTOS}

À Professora Dra. Evelin Naked de Castro Sá, meus sinceros agradecimentos pela orientação prestada e pelo incentivo durante a realização do meu trabalho acadêmico.

À Professora Dra. Marluce Maria Araújo Assis, pelo incentivo e contribuições.

À Professora Dra. Márcia Westphal, pelas importantes contribuições na elaboração do Projeto de Pesquisa e ao apoio de todo o grupo do CEPEDOC durante o estágio na FSP/USP.

Aos examinadores, pela contribuição no aperfeiçoamento do trabalho.

À Universidade Estadual de Feira de Santana, representada por seus dirigentes, por proporcionar a realização do curso de Doutorado em Saúde Pública.

A Lydia de Brito Santos, pelo carinho e colaboração na elaboração do trabalho.

Aos familiares, pelo apoio constante.

Aos colegas do Departamento de Saúde, em especial aos professores Marisa Mélo, Maria Ângela de Merícia, Marluce Assis, Tereza Cristina Costa, Laura Zatti, Aline Mota, Maria Lúcia Servo, Luciana Toso, Silvone Santa Bárbara, Cristina Camargo e Deybson Almeida, por terem facilitado meu afastamento.

Aos funcionários da coordenação de Pós-graduação em especial ao Professor Guido Rummler e a secretária Tânia Lago, pelo apoio e dedicação.

Aos queridos colegas do doutorado, pelo companheirismo e pela solidariedade, em especial, Robéria Lúcia, pela amizade e compreensão.

Aos bolsistas e colegas do Laboratório de Informática, em especial ao Professor Mário pela atenção.

Aos amigos que contribuíram na coleta de dados Anilton, Obede e Marieta pelo carinho e atenção.

À Professora Graça Simões, pela presteza e competência na revisão bibliográfica do texto.

Ao Prof ${ }^{\circ}$ Gerônimo, pela criteriosa revisão de parte do texto,

À Nivaldo e Elisângela, pelos preciosos serviços que extrapolam as questões técnicas. 
Queiroz, CMB. Qualidade de vida e políticas públicas no município de Feira de

Santana. São Paulo; 2002 (Tese de Doutorado - Faculdade de Saúde Pública da USP).

\section{RESUMO}

Objetivo. Análise das políticas públicas do município de Feira de Santana relacionadas à qualidade de vida da população, expressa no índice de desenvolvimento humano. Foi realizada uma descrição da dotação orçamentária do município no período de 1993 a 2002, enfocando as políticas públicas e ações de governo relacionadas ao índice de desenvolvimento humano nas áreas de educação saúde e meio ambiente. O referencial teórico está embasado em qualidade de vida, políticas públicas e cidadania. Método. Estudo descritivo, que explora aspectos quantitativos e qualitativos através da análise da Lei Orgânica, do orçamento municipal e de entrevistas com secretários do município. Resultados. A análise temática revelou que a Lei Orgânica do Município contém as diretrizes orientadoras das políticas públicas. A área da educação possui o maior orçamento do município e apresenta $20 \%$ de analfabetismo. Implementa, entre outros, curso de alfabetização de jovens e adultos. Na área da saúde; houve aumento de $34 \%$ no orçamento para o ano de 2002, com a perspectiva de mudança para a condição de Gestão Plena do Sistema de Saúde. Há melhoria dos índices de esperança de vida ao nascer e de mortalidade infantil nas últimas décadas. Na área de meio ambiente a dotação orçamentária é baixa em relação às necessidades do município; a legislação é avançada. Há déficit de $70 \%$ na cobertura de esgotamento sanitário e degradação ambiental através da ocupação irregular das Lagoas. Considerações finais. As ações desenvolvidas nas áreas de educação e saúde possuem as maiores dotações orçamentárias na década analisada e estas mantêm convênio com outros órgãos para desenvolver atividades programáticas complementares. A área de meio ambiente possui legislação avançada, porém baixa dotação orçamentária, dependendo de financiamento externo para implantar e implementar as ações necessárias de saneamento básico.

Descritores: Qualidade de Vida. Políticas Públicas. Promoção da Saúde. Orçamento Municipal. 
Queiroz, CMB. Qualidade de vida e políticas públicas no município de Feira de

Santana. [Life quality and public policies in Feira de Santana borough] Feira de Santana - BR; 2002 [Doctorate Thesis - Public Health College at USP].

\section{SUMMARY}

Objective. Analysis of public policies in Feira de Santana borough related to the population's life quality expressed in the human development index. A description of the county budget prediction and execution during the period of 1993 to 2002 was made, focusing on public policies and government actions related to the human development index in the educational, health and environmental areas. Methodology. Descriptive study which explores quantitative and qualitative aspects through the analysis of the Organic Law, the county budget and interviews with county secretaries. Results. The thematic analysis revealed that the County Organic Law contains the premises that guide public policies. The educational area has got the greatest budget of the county and shows a $20 \%$ illiteracy rate. It implements literacy courses for the youth and adults among others. In the health area there has been a $34 \%$ increase in the budget for the year 2002 with the perspective of change into Health System Full Management. There has been an increase in the indexes of life expectancy of the newly born and children in the last decades. In the environmental area the budget dotation is low in relation to the county needs and the law is modern. There is a $70 \%$ deficit in covering the sewerage system, and environmental degradation through the irregular occupation of the Ponds. Final comments. The actions developed in the educational and health areas have the greatest budget dotations in the analyzed decade and keep partnership with other institutions in order to develop complementary program activities. The environmental area has got modern laws, however low budget dotation, therefore depending on external funding to implement necessary basic sewerage actions.

Descriptors: Life Quality. Public Policies. Health Promotion. borough Budget. 


\section{LISTA DE QUADROS}

Quadro 01 - Crescimento do ICV em 12 capitais brasileiras em 1999

Quadro 02 - Esquema de Análise das Entrevistas - Núcleos de Sentido

60

Quadro 03 - Esquema de Análise dos Dados - Unidades Temáticas

61

Quadro 04 - Algumas competências do Município de Feira de Santana contidas na Lei Orgânica nas áreas de Educação, Saúde e Meio Ambiente.

Quadro 05 - Índice de Desenvolvimento Humano (IDH) de Feira de Santana - BA, nos anos de 1970, 1980, e 1991

Quadro 06 - Índice de Condições de Vida (ICV) em Feira de Santana - Bahia, nos anos de 1970, 1980, e 1991

Quadro 07 - Índice de ICV - \% de dados sobre longevidade e mortalidade infantil nos anos de 1970, 1980, 1991. Feira de Santana - Bahia

Quadro 08 - Índice de ICV - \% de dados sobre educação nos anos de 1970, 1980, 1991. Feira de Santana - Bahia

Quadro 09 - Índice de ICV - \% de dados sobre a infância nos anos de 1970, 1980, 1991. Feira de Santana - Bahia

Quadro 10 - Índice de ICV - \% de dados sobre Renda nos anos de 1970, 1980, 1991. Feira de Santana - Bahia 
Quadro 11 - Índice de ICV - \% de dados sobre Habitação nos anos de 1970, 1980, 1991. Feira de Santana - Bahia

Quadro 12 - Evolução do Orçamento Público do Município de Feira de Santana de 1993 a 2002

Quadro 13 - Evolução do Orçamento Público do Município de Feira de Santana de 1993 a 2002 (cont.)

Quadro 14 - Dotação orçamentária em percentual, por rubrica, nas áreas de educação, saúde e meio ambiente, entre 1993 e 2002. Feira de Santana - BA 


\section{LISTA DE FIGURAS}

Figura 1 - Políticas Públicas, Qualidade de vida e Cidadania

Figura 2 - Vista Parcial da Cidade de Feira de Santana

Figura 3 - Rua Sales Barbosa - Antiga Praça do Comércio

Figura 5 - Articulação das Rodovias Estaduais e Federais em Feira de Santana 44

Figura 6 - Gráfico da Evolução do Orçamento Municipal de Feira de Santana em milhões de reais no período de 1995 a 2002

Figura 7 - Gráfico da evolução da dotação orçamentária em percentuais, nas áreas de Educação, Saúde e Meio Ambiente, entre 1993 e 2002 Feira de Santana - Bahia -

Figura 8 - Mapa de Localização das Lagoas de Feira de Santana em relação às ruas principais

Figura 9 - Foto da Lagoa Grande. Feira de Santana, 1997

Figura 10 - Foto da Lagoa do Prato Raso com ocupação irregular. Feira de Santana, 1997

Figura 11 - Foto da Lagoa Grande com ocupação irregular. Feira de Santana 1997 


\section{ÍNDICE}

1 INTRODUÇÃO 1

2 MARCO TEÓRICO 8

$\begin{array}{ll}2.1 \text { Qualidade de Vida } & 10\end{array}$

2.1.1 Concepções de Saúde e Doença 15

2.1.2 Promoção da Saúde e o Movimento por Cidades Saudáveis 19

2.2 Cidadania 22

2.3 Políticas Públicas $\quad 26$

2.3.1 Concepções e Reforma de Estado 28

2.3.2 Financiamento das Políticas Públicas 34

3 OBJETIVOS 40

3.1 Objetivo Geral 40

3.2 Objetivos Específicos 40

4 Cenário da Pesquisa 41

4.1 Histórico do Município 41

4.2 Aspectos Físicos e Espaciais $\quad 43$

4.3 Aspectos Demográficos e Renda $\quad 45$

4.4 Educação 46

$\begin{array}{ll}4.5 \text { Saúde } & 47\end{array}$

4.5.1 Principais Indicadores Epidemiológicos 48

4.5.2 Coeficiente de Natalidade e Fecundidade $\quad 49$

4.5.3 Mortalidade Infantil $\quad 50$

4.5.4 Mortalidade Geral $\quad 50$

4.5.5 Índice de Swaroomp Uemura 51

4.6 Saneamento Básico 51

5 METODOLOGIA 53

5.1 Tipo de Estudo $\quad 53$

5.2 Estratégias de Investigação 54

5.3 Análise Quantitativa 54

5.4 Análise Qualitativa $\quad 55$

5.5 Etapa Exploratória $\quad 56$ 
5.6 Coleta de Dados nas Entrevistas 56

$\begin{array}{lll}5.7 & \text { Sujeitos da Pesquisa } & 57\end{array}$

5.8 Análise dos Dados Empíricos 58

6 RESULTADOS E DISCUSSÃO 63

6.1 Lei Orgânica como orientadora da gestão e planejamento das ações no âmbito municipal 63

6.2 As políticas públicas e o índice de desenvolvimento humano $\begin{array}{ll}\text { em Feira de Santana } & 70\end{array}$

6.3 O Orçamento anual do município e o financiamento das 77 políticas públicas

6.4 Política de Educação para o Município de Feira de Santana 85

6.5 Política de Saúde para o Município de Feira de Santana 98

5.6 Política de Meio Ambiente para Feira de Santana 105

7 CONCLUSÕES 116

8 REFERÊNCIAS 119

ANEXOS

Anexo 1 - Termo de consentimento Livre e Esclarecido

Anexo 2 - Roteiro de Entrevista

Anexo 3 -Declaração de Alma-Ata 


\section{INTRODUÇÃO}

Qualidade de Vida é uma expressão que se vem tornando corriqueira no dia a dia das pessoas, mas que se reveste de grande complexidade, dada a subjetividade que representa para cada pessoa ou grupo social, podendo representar felicidade, harmonia, saúde, prosperidade, morar bem, ganhar salário digno, ter amor e família, poder conciliar lazer e trabalho, ter liberdade de expressão, ter segurança. E pode significar todo esse conjunto de atributos e/ou benefícios.

Qualidade de vida é compreendida, no presente trabalho, como parte de um bem individual e coletivo, entendendo a saúde como uma condição biológica, psicológica e social determinada por fatores objetivos, do ponto de vista das necessidades de subsistência, e fatores subjetivos, considerando as necessidades sociais de realização do ser humano (Westphal citado por MINAYO et al. 2000).

Quanto maior a capacidade das pessoas de controlarem os fatores objetivos e subjetivos que determinam a qualidade de vida, e o nível de participação da sociedade civil organizada nas decisões sociais, maior será a capacidade de alcançar um melhor grau de qualidade de vida e, conseqüentemente, o desenvolvimento humano em consonância com o conceito de qualidade de vida de Amartya Sem, ao influenciar o Índice de Desenvolvimento Humano da Organização das Nações Unidas (ONU).

SEN (1999; 2002), aponta que, quanto maior a capacidade das pessoas desempenharem os papeis constitutivos, relacionados às liberdades substantivas e papéis instrumentais, referentes aos diferentes tipos de direitos e oportunidades, maiores serão as possibilidades de expansão das liberdades para o desenvolvimento humano.

O autor ainda afirma que as liberdades substantivas incluem as condições elementares de vida e relacionam-se aos direitos de não passar privações como fome, subnutrição, analfabetismo e falta de moradia e, nesse sentido, a qualidade de vida de um povo é influenciada pela história, pela cultura e, sobretudo, pelas condições sociais e econômicas, para resolver suas necessidades básicas de subsistência.

Há uma grande diferença, ao se abordar a questão da qualidade de vida para uma nação que tenha suas questões sociais resolvidas, e para outra, em que isso não 
ocorra. Quando, em 1984, foi realizada uma enquete em Toronto - Canadá, em que se perguntava às pessoas como queriam que fosse sua cidade, as respostas foram: limpa, verde, que tivesse vida própria e que fosse agradável para viver (LEE 1984). Certamente que, se essa pergunta fosse feita no Brasil, hoje, é provável que, nas respostas, estivessem presentes assuntos relacionados à renda, saúde, educação e segurança.

O conceito de qualidade de vida assume, pois, contornos que são inerentes às características de cada população, e, nessa direção, a concepção de Promoção da Saúde, tal como foi utilizada, com êxito, no Canadá, vem sendo associada a um conjunto de condições necessárias a sua implementação, aliada à vontade política do governo e ao envolvimento da população com base na Declaração de Alma-Ata (Anexo 3).

Nas propostas da Declaração de Alma-Ata (1978), é fundamental que haja desenvolvimento econômico e social voltado para os principais problemas da comunidade, proporcionando serviços de promoção, prevenção, cura e reabilitação, de acordo com suas necessidades e com base na intersetorialidade.

Para que uma sociedade conquiste saúde para todos são necessárias: uma ação intersetorial e a implementação de políticas públicas saudáveis (BUSS 1996). A relação intersetorial está enfocada na lógica da Declaração de Alma-Ata, que se dá com a integração entre o setor saúde e os demais setores de desenvolvimento nacional e comunitário, desde a agricultura e pecuária, produção de alimentos, indústria, educação, habitação, obras públicas, comunicações, entre outros. Essa lógica foi a diretriz orientadora do Movimento por Cidades Saudáveis.

Este movimento teve início em 1984 em Toronto, Canadá (LEE 1994) e se consolida com a realização da Primeira Conferência Internacional sobre Promoção da Saúde, em que foi elaborada e divulgada a Carta de Otawa (MS 1996).

A Carta de Ottawa afirma ser a saúde um conceito positivo, um recurso para o desenvolvimento social, econômico e pessoal, assim como uma importante dimensão da qualidade de vida.

Assim sendo, a saúde pode ser produzida por meio da intervenção em todo o processo saúde-doença e no seu complexo de determinantes, o que se coaduna com a proposta do Sistema Único de Saúde (SUS), como política social, tendo como 
referencial básico o artigo 196 da Constituição Federal, que diz: "A saúde é direito de todos e dever do Estado, garantido mediante políticas sociais e econômicas que visem a redução do risco de doença e de outros agravos, o acesso universal e igualitário às ações e serviços para a sua promoção e recuperação" (BRASIL 1988).

Entende-se que um dos pontos relevantes, neste estudo, é a articulação com o processo de descentralização administrativa, via municipalização da saúde. Assim, o Sistema Único de Saúde (SUS), enquanto política pública nacional, orientado com base nas diretrizes de universalidade de acesso aos serviços, integralidade das ações de saúde, equidade, no sentido de promover assistência de acordo com as necessidades da população, e participação social, é referencial da política de saúde para o município de Feira de Santana, que se encontra na condição de Gestão Plena da Atenção Básica e pleiteia a condição de Gestão Plena do Sistema de Saúde conforme a Norma Operacioanl Básica de 1996 (NOB.SUS/96).

Entretanto, a universalização dos direitos depende efetivamente do empowerment da população, que, por sua vez, é fortemente determinada pela conjuntura social, política e econômica que se materializa através de políticas públicas e que, ao serem implementadas, têm o papel de atender às necessidades de cidadania e de reduzir as desigualdades sociais.

As políticas públicas teriam que refletir a responsabilidade do Estado em administrar os bens que lhes são confiados pela sociedade. Considerando que tais benefícios necessitam ser conquistados, é oportuna a colocação gramsciana sobre hegemonia, como a capacidade de descobrir as características específicas de uma dada sociedade, e de se antecipar na ação.

Para GRAMSCI (1991), " o Estado é todo um complexo de atividades práticas e teóricas, com as quais as classes dirigentes justificam e mantêm não só o seu domínio, mas o consentimento ativo dos governantes". E, por isso, indica a tomada de posições como forma de explorar e romper barreiras.

Um estudo sobre políticas públicas e qualidade de vida envolve uma questão técnica e uma questão política, pela responsabilidade de despertar a organização pública para aliar a condição de sua execução à dotação orçamentária e a busca da melhoria das condições de vida para a população. 
PEREIRA JM (1999) afirma que a função política do Estado é promover o bem comum de acordo com a moral e a ética, e que as políticas públicas estão diretamente relacionadas com questões de cidadania, guiadas pelos ideais de liberdade, igualdade e solidariedade, para o controle democrático sobre o Estado. Inclui, também, o direito à satisfação de necessidades básicas, como emprego, educação, saúde, habitação, entre outros.

Para formulação da agenda de políticas públicas, segundo PEREIRA (1999), observam-se várias tendências: a racionalidade econômica que se assemelha à de economia de mercado; a racionalidade político sistêmica, a partir de acordos políticos, e o modelo da formulação responsável de políticas públicas com base em justificativas morais.

Vale salientar que a formulação da agenda de políticas púbicas envolve múltiplos interesses sociais e sobre isso Gramsci, citado por ASSIS (1998, p.62), diz que a divisão de poderes é resultado da luta entre as sociedades, civil e política em ação. As disputas e conquistas vão depender da conjuntura e dos sujeitos políticos. Assim sendo, o êxito, que poderá ser revertido em política pública, deverá ser proporcional à capacidade de luta de cada grupo social, que, com suas representações, podem influenciar o processo de mudança ou manter a ordem estabelecida pelos grupos dominantes.

PEREIRA JM (1999) lança uma provocação, situando a importância da articulação entre Estado e sociedade civil no encaminhamento e formulação das políticas públicas, cabendo ao Estado o papel de facilitador e regulador do processo, sendo a ação decisória um processo do jogo de poder entre grupos de pressão organizados, que defendem interesses específicos, tornando-se necessário que a sociedade passe a participar, de maneira mais ativa, das discussões que tratam da formulação e implementação de políticas públicas. Dessa participação deve resultar, de forma gradativa, a substituição das soluções de interesse pessoal ou de grupos, por soluções de caráter estrutural e de alcance coletivo.

No Estado moderno, com o avanço dos processos democráticos, cabe ao governante e à sociedade, através da participação nas decisões, a responsabilidade pelas políticas públicas. 
Para TESTA (1992), a democracia é uma condição necessária ao capitalismo, na medida que representa uma garantia de liberdade, como capacidade dos empresários para demandar força de trabalho e dos operários de serem livres para vendê-la.

Uma outra abordagem, referida por MOTTA (1998), diz respeito à concepção gerencial moderna, em que as organizações procuram romper com as limitações burocráticas extensivas, ganhando maior flexibilidade para adaptação às adversidades e à ambiência, gerando grande capacidade de decisão e ação. As decisões descentralizadas são mais rápidas porque escapam das redes centrais burocráticas.

O autor citado afirma que descentralizar significa colocar a decisão o mais próximo possível da clientela e do local da ação, onde existam todas as informações necessárias à decisão.

A reflexão apontada vem tomando corpo no cenário nacional com o processo de redemocratização, assegurado na Constituição Federal de 1988 que indica a necessidade de modernização do Estado, o fortalecimento do poder local através de estratégias descentralizadoras, que permitem a participação social na gestão colegiada dos espaços institucionais regulados pelo Estado.

$\mathrm{Na}$ luta por mais cidadania e por mais democracia, coloca-se a abordagem de CARVALHO (2000) sobre o marco que representa essa Constituição, em que duas características marcam o novo Estado Servidor, em contraposição ao Estado Usurpador, anterior: a descentralização do poder e dos recursos, e o avanço da cidadania, abrindo a possibilidade dos cidadãos controlarem melhor a União, os Estados e Municípios, com o fortalecimento significativo dos Municípios e a previsão de financiamento das áreas de saúde e educação. Esses financiamentos dependem de lei complementar, que, na área de educação, só começaram a ocorrer oito anos depois, com a regulamentação da Emenda Constitucional No 14 / 1996 pela Lei $9424 / 1996$.

$\mathrm{Na}$ área da saúde, o financiamento do SUS ainda é um problema a ser resolvido pois depende da soluções de problemas macroeconômicos, como a crise fiscal e financeira do Estado brasileiro (MENDES et al. in WESTFHAL E ALMEIDA ES 2001). 
$\mathrm{Na}$ segunda metade da década de 80 o governo brasileiro, atendendo a pressões dos credores internacionais, avalia a crise econômica, gerada pelo esgotamento da estratégia de substituição às importações com subsídios do governo às empresas privadas, tendo como consequiência a diminuição da poupança pública, aumento da dívida interna e externa, falta de crédito e credibilidade do Estado, gerando crise fiscal. O governo propõe a Reforma do Estado com o objetivo de imprimir reformas estruturais, reduzindo o tamanho do Estado e definindo uma nova estratégia de desenvolvimento (PEREIRA LCB 1996).

O papel do Estado é revisto conforme o Plano Diretor de Reforma do Aparelho de Estado de 1995, visando às condições para modernização da Administração Pública e buscando governabilidade com apoio da sociedade civil, e capacidade de implementação das políticas públicas com maior eficiência e flexibilidade da máquina administrativa (MARE 1995).

MENDES EV (1996) analisa que a implementação das políticas públicas depende das macro-estruturas do País, mas se dá efetivamente nos Municípios, local em que os cidadãos vivem e morrem, ao passo que Estados e União são abstrações imprescindíveis, que representam recortes abstratos de conformação de territórios político-administrativos

Não obstante os grandes problemas sociais ainda presentes no Brasil, gerados, especialmente, pela enorme desigualdade na distribuição de renda, entende-se que o tema deste trabalho é instigante, na medida em que põe em evidência a necessidade de discutir sobre a relação entre políticas públicas e qualidade de vida do cidadão, como forma de lutar por desenvolvimento humano e cidadania.

Diante da relevância que representa este trabalho na identificação das necessidades da população da segunda maior cidade do Estado da Bahia, considerando que o município possui estruturação coerente com as exigências das constituições, estadual e federal e também pela importância de entender a saúde como um conceito positivo de qualidade de vida, tomam-se como eixo orientador as seguintes questões:

- quais os aspectos das políticas públicas, no município de Feira de Santana, que estão voltados para a qualidade de vida expressa no Índice de Desenvolvimento Humano; 
- quais as coerências e incoerências entre as propostas consignadas nos documentos oficiais e a execução das ações nas áreas de educação, saúde e meio ambiente do município de Feira de Santana.

O presente estudo está estruturado em sete partes, procurando refletir as questões problematizadas, permeadas pelo marco teórico e os dados empíricos da pesquisa. $\mathrm{Na}$ primeira, foram abordados os conceitos gerais sobre qualidade de vida respaldada na promoção da saúde, a cidadania como eixo entre qualidade de vida e políticas públicas e estas a partir do conceito de Estado. Na segunda parte foi estruturado o marco teórico, enfocado em três temas: qualidade de vida com base nas concepções de saúde e doença e na promoção da saúde; cidadania, enfocando as formas de participação, e políticas públicas, enfocando as concepções e reforma de Estado e o financiamento das políticas públicas. Na terceira estão delineados os objetivos geral e específicos. Na quarta parte foi apresentado o cenário da pesquisa, caracterizando o Município de Feira de Santana no Estado da Bahia. Na quinta foi descrita a metodologia de caráter qualitativo utilizada no estudo. Na sexta parte foram apresentados os resultados em seis itens: 1. Lei Orgânica como orientadora da Gestão e do planejamento das ações no âmbito municipal; 2. As políticas públicas e o índice de desenvolvimento humano em Feira de Santana; 3. O orçamento anual do município e o financiamento das políticas públicas; 4. Política de educação para o município de Feira de Santana; 5. Política de Saúde para o município de Feira de Santana; 6. Política de meio ambiente para Feira de Santana. Na sétima parte foram apresentadas as conclusões, de acordo com os objetivos da pesquisa. 


\section{MARCO TEÓRICO}

O marco teórico da pesquisa procura explicitar a indissociabilidade e complementaridade entre qualidade de vida, políticas públicas e cidadania, funcionando esta última como um eixo integrador entre políticas públicas e qualidade de vida.

Qualidade de vida, de acordo com o conceito positivo de saúde, será enfocada no contexto histórico do processo saúde-doença e da promoção da saúde, através do movimento por cidades saudáveis. Políticas públicas, como instrumento do poder público para promover qualidade de vida, sob o olhar vigilante e a ação política dos cidadãos, enfocando as concepções, reforma do Estado e financiamento das políticas públicas.

O conceito de saúde tem evoluído através dos tempos, incorporando-se ao texto constitucional, como uma condição que deve ser produzida socialmente. A introdução do conceito de saúde ao texto constitucional de 1988 significa uma conquista do Movimento da Reforma Sanitária Brasileira, que em 1986, durante a oitava Conferência Nacional de Saúde realizou o maior evento político da saúde coletiva ocorrido no País (LUZ 1994), e manteve a mobilização necessária durante os trabalhos da Constituinte.

O ano de 1986 é paradigmático também no fórum internacional, marcado pela Primeira Conferência Internacional de Saúde sobre Promoção da Saúde, gerando a Carta de Otawa, em novembro de 1986. Promoção da Saúde é expressão utilizada para indicar o processo de capacitação da comunidade para atuar na melhoria de sua qualidade de vida e saúde, incluindo uma maior participação social no controle desse processo (MS 2001).

Nessa concepção a cidadania representa o elo de ligação entre qualidade de vida e políticas públicas, na medida em que a consciência de cidadania significa o fortalecimento do poder de participação ilustrado na Figura 1. 


\section{FIGURA 1}

Políticas Públicas Qualidade de Vida e Cidadania

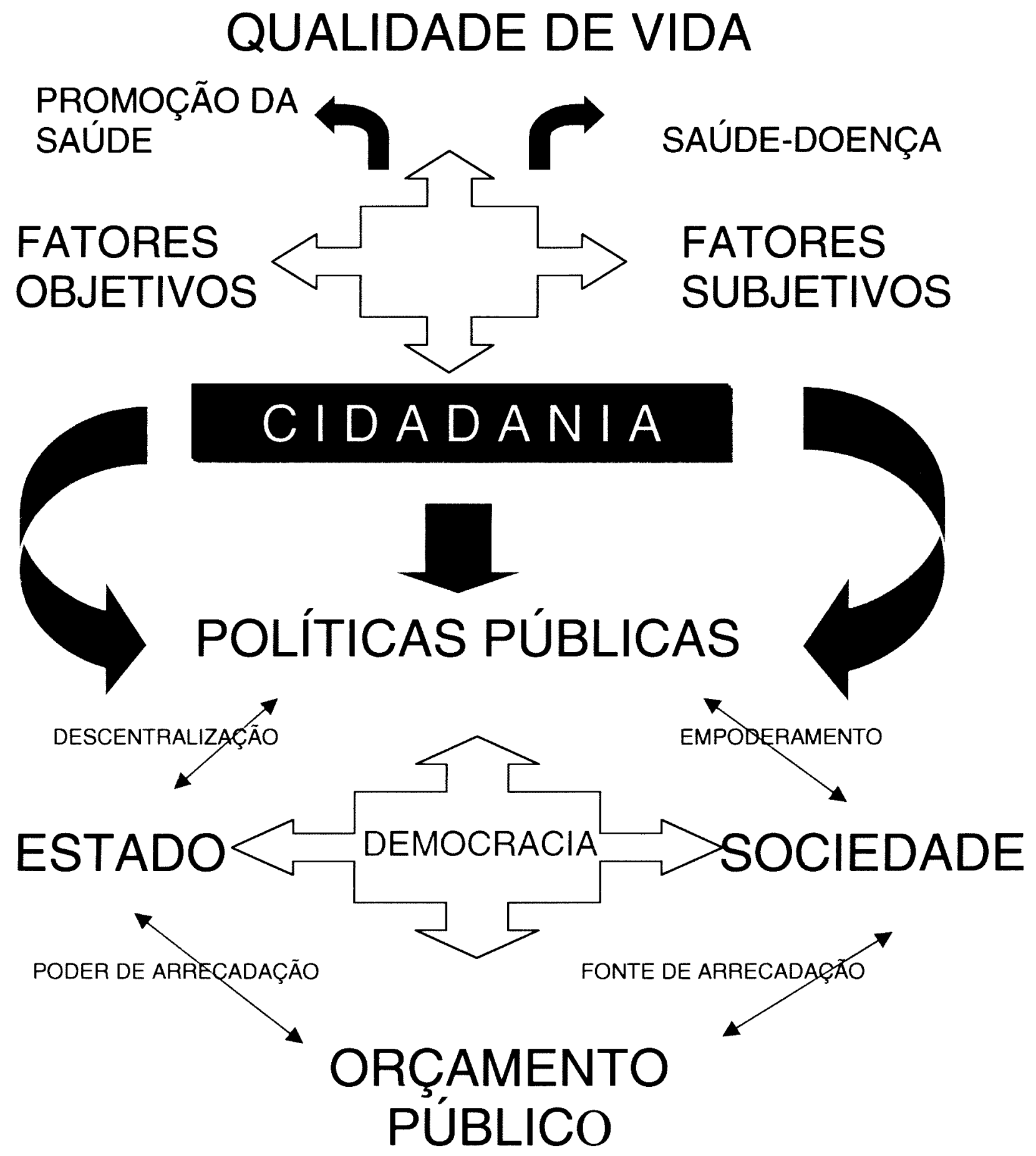

Quadro explicativo do marco teórico 


\subsection{Qualidade de Vida}

Controlar os fatores determinantes de qualidade de vida é, também, a evidência do "empoderamento" da sociedade e, através deste, a possibilidade de poder influenciar, diretamente, via participação social nos fóruns de decisões, e indiretamente, forçando o processo de descentralização do Estado, fazendo com que este cumpra o seu papel na promoção do bem comum, aproximando, ao máximo, o orçamento público e as decisões políticas às reais necessidades da população. Ao conceituar qualidade de vida, SEN e NUSSBAUM, citado por CROCKER (1993, p.99) dão ênfase à ética do desenvolvimento global e reforçam as orientações teóricas sobre desenvolvimento e a satisfação de necessidades básicas. De acordo com SEN (1985), Aristóteles já demonstrava preocupação com o bem estar das pessoas com base na teoria política da distribuição.

SEN (1985) enfatiza o aspecto valorativo do desenvolvimento no sentido de mostrar que o crescimento econômico é um meio para a aquisição de qualidade de vida e, tendo como objeto último melhorar a vida das pessoas. Articula a adequação moral da capacidade de possuir bens e utilidades e o direito de optar por eles; instiga a superação de fronteiras nacionais e culturais para a construção de uma ética global; reconhece que a ética do desenvolvimento precisa ser elaborada em relação à dialética da investigação sobre as causas que impedem o desenvolvimento.

Para Amartya Sen, o Índice de Desenvolvimento Humano (IDH) é imperfeito, mas pode ser visto como um movimento introdutório para se conseguir o interesse das pessoas pelo conjunto de informações contidas no Relatório de Desenvolvimento Humano. O fato de estar centrado em indicadores de longevidade, educação e renda per capita e não se centrar apenas na riqueza econômica alarga a visão empírica da avaliação que os processos de desenvolvimento recebem (FUNDAÇÃO SEADE 2001).

O autor citado influenciou o relatório do Plano das Nações Unidas para o Desenvolvimento (PNUD), quando propôs um novo índice de desenvolvimento humano como forma de medir os êxitos e deficiências do desenvolvimento, cuja análise causal deve orientar as políticas públicas ao reconhecer que a ética do desenvolvimento precisa ser abordada em relação à dialética da investigação sobre as 
causas que influenciam o desenvolvimento, ou que produz a pobreza, a carência de alimentos e outras deficiências do desenvolvimento humano.

Em sintonia com o pensamento de Sen, NUSSBAUN (1993), utiliza a Teoria da Justiça de Rawls, na qual são considerados bens primários numa estrutura eqüitativa de renda e oportunidades de escolha e, nesta, as liberdades fundamentais (de consciência, política e de movimento). Entendendo-se que tais requisitos são necessários à cidadania democrática, considerando que cabe aos cidadãos e não ao Estado, a decisão acerca de seus próprios objetivos.

A Teoria da Justiça já foi tema de debate entre John Rawls e Habermas, em 1995. O sistema filosófico de Rawls defende a doutrina do contrato social, propondo um modelo de sociedade justo, onde prevalece a concepção de justiça como equidade construída. O mérito da teoria de Rawls é ter desenvolvido um sistema filosófico que consegue dar conta de temas como a universalização rigorosa sobre uma proposta de obrigações morais, num contexto de sociedades pluralistas e democráticas, sem apelar para procedimentos metafísicos (LAVALLE 1997).

HABERMAS (1989) refere que, desde a publicação da "Teoria da Justiça" de Rawls, Kholberg se utiliza dessa ética, que se liga ao pensamento de Kant e ao direito natural racional, para precisar suas concepções filosóficas sobre a natureza do juízo moral.

A noção de desenvolvimento humano, ao mesmo tempo em que enfatiza a necessidade de crescimento econômico, afirma que é preciso enfocá-lo no desenvolvimento das pessoas, pois, nem sempre, crescimento econômico tem uma relação direta com o desenvolvimento humano, haja vista a experiência brasileira que, mesmo tendo ocupado o $8^{\circ}$ lugar, em 1994 e $11^{\circ}$ em 2001 na economia mundial, de acordo com o valor do Produto Interno Bruto - PIB (Fórum Mundial 2002 -Porto Alegre), é o país detentor de maior número de pessoas pobres, com $34 \%$ da população vivendo abaixo da linha de pobreza (IBGE 2000).

Pode-se, assim, inferir que quanto maior a concentração de renda, maior será a distância de acesso aos bens de consumo básicos pelos menos favorecidos, o que, conseqüentemente, será revelado pelos baixos indicadores de desenvolvimento humano. 
O Brasil tem uma das estruturas de renda mais concentradas do mundo. Em 1996, o índice de Gini brasileiro (que expressa a concentração de renda), encontrava paralelo apenas nos de Serra Leoa e Suazilândia, na África, ficando atrás de todos os países da América Latina (FUNDAÇÃO SEADE 2001). Esses dados são alarmantes, quando se reconhece que essa condição não é compatível com o desenvolvimento da economia brasileira, a despeito do desequilíbrio regional.

O índice de Gini é uma das principais medidas de desigualdade de renda. É uma medida de dispersão relativa, associada à curva de Lorenz. A área entre a linha perfeita de igualdade e a curva de Lorenz é a área de desigualdade representada por alfa maior ou igual a zero e menor ou igual a zero vírgula cinco (HOFFMANN 1998).

Na aplicação do índice de Gini, a estrutura de concentração de renda é a razão entre a média dos $20 \%$ mais ricos e dos $20 \%$ mais pobres da população.

A maioria dos países apresenta uma razão inferior a $10 \%$, enquanto que o Brasil está entre os cinco países que apresentam uma razão acima de $20 \%$, revelando um índice Gini de 0,60. Os países sulamericanos possuem esse índice entre 0,45 e 0,60 e os países desenvolvidos, entre 0,30 e 0,40 (BARROS 2000).

De acordo com dados de GUIMARÃES (1996), desde 1960, o crescimento econômico, no Brasil, foi sempre acompanhado de redução da pobreza e melhoria do bem estar, ainda assim o Brasil mantém um dos maiores índices de desigualdade social do mundo.

O conceito de desenvolvimento humano preconizado pelo Programa das Nações Unidas para o Desenvolvimento, de acordo com GUIMARÃES (1996) é mais abrangente que o conceito de desenvolvimento econômico, o que não significa que este não seja importante, pois isso implica em aumento da produção e produtividade e, consequiente, ampliação das oportunidades de emprego produtivos e adequadamente remunerados, entretanto, os investimentos para o crescimento econômico devem ser decididos a partir de critérios que envolvam, concomitantemente, o desenvolvimento das pessoas, constituindo-se no primeiro componente do desenvolvimento humano.

$\mathrm{O}$ autor refere ainda que a equidade aparece como o segundo componente essencial ao desenvolvimento humano. A desigualdade e a pobreza são as maiores 
barreiras à participação social. A equidade, portanto, deve ser construída através de investimentos em saúde, educação e capacitação da população para que ela se integre na vida econômica, política, social e cultural do país.

O desenvolvimento sustentável é colocado como o terceiro componente essencial do desenvolvimento humano. Embora o processo de industrialização, ao longo do tempo, tenha concorrido para a degradação ambiental, seja pela utilização acelerada dos recursos naturais, seja pela urbanização desordenada, ressalta-se que a pobreza por si só é uma fonte de degradação ambiental.

O quarto componente essencial colocado no relatório do PNUD é a participação nas decisões - empowerment. A participação nos processos de decisões sociais pode ser incentivada pela descentralização das estruturas administrativas e, conquistada, por pressões das lutas sociais.

O objetivo do desenvolvimento humano é criar um ambiente no qual as pessoas possam expandir suas capacidades e no qual se ampliem as oportunidades de realizações (GUIMARÃES 1996).

O Índice de Desenvolvimento Humano, calculado desde 1990, enfatiza três opções básicas: "desfrutar uma vida longa e saudável, adquirir conhecimento e ter acesso aos recursos necessários para uma vida decente". O IDH busca combinar e articular os três componentes, sendo os dois primeiros incorporados como valores em si mesmos e o último como meio para outros fins.

A pobreza no Brasil assume vários aspectos críticos, na zona rural da Região Nordeste, em consequiência da seca e na periferia das grandes cidades com o processo de favelização a que vêm sendo submetidos os grandes centros urbanos, deixando os bairros de classe média espremidos por um cinturão de pobreza e criminalidade que cresce cada vez mais (GUINMARÃES 1996).

O Relatório de Desenvolvimento Humano (PNUD/IPEA 1998), ao classificar a qualidade de vida nas 12 principais capitais do País, indica Salvador, capital do Estado da Bahia, ocupando $o \quad 11^{\circ}$ lugar na conjugação dos Índice de Desenvolvimento Humano (IDH) e Índice de Condições de Vida (ICV) e o $12^{\circ}$ lugar na classificação do ICV (ver quadro 1). 


\section{Quadro 1 - Crescimento do ICV em 12 capitais brasileiras em 1999}

\begin{tabular}{c|c|c}
\hline $1^{\circ}$ & São Paulo & $28,8 \%$ \\
\hline $2^{\circ}$ & Curitiba & $11,0 \%$ \\
\hline $3^{\circ}$ & Goiânia & $10.0 \%$ \\
\hline $4^{\circ}$ & Fortaleza & $9.5 \%$ \\
\hline $5^{\circ}$ & Belo Horizonte & $7,8 \%$ \\
\hline $6^{\circ}$ & Porto Alegre & $7,5 \%$ \\
\hline $7^{\circ}$ & Rio de Janeiro & $5,9 \%$ \\
\hline $8^{\circ}$ & Brasilia & $5,6 \%$ \\
\hline $9^{\circ}$ & Recife & $5,2 \%$ \\
\hline $10^{\circ}$ & Belém & $3 ., 9 \%$ \\
\hline $11^{\circ}$ & Manaus & $3,0 \%$ \\
\hline $12^{\circ}$ & Salvador & $\mathbf{0 , 6} \%$ \\
\hline
\end{tabular}

Fonte: PNUD/IPEA/IBGE

Nos últimos 10 anos, a população das oito maiores cidades do país, São Paulo, Rio de Janeiro, Belo Horizonte, Curitiba, Recife e Salvador, saltou de 37 milhões de habitantes para 42 milhões, sendo que a taxa de crescimento da periferia foi de $30 \%$ contra 5\% das regiões mais ricas. Do ano de 1996 para cá, a renda per capita, nas cidades médias brasileiras, cresceu $3 \%$, enquanto nas periferias das grandes cidades a renda caiu $3 \%$. A periferia das grandes cidades, há dez anos, apresentava taxas de 30 homicídios por 100.000 habitantes, atualmente, em algumas áreas pobres, as taxas chegam a 150 mortes por 100.000 habitantes de acordo com TOLOSA (2001).

Estes dados demonstram que o Brasil possui um dos mais elevados graus de iniqüidade, agravado em grande parte pela instabilidade econômica do país nas décadas de setenta, oitenta e início dos anos noventa. A desigualdade de renda no Brasil necessita ser enfrentada a partir do envolvimento de toda a sociedade através da conscientização política, social e econômica, associada à vontade política de imprimir mudanças (RAMOS e VIEIRA 2001).

Os autores afirmam que durante os anos de 1997 e 1999, o mercado de trabalho perdeu parte de sua capacidade de gerar postos de trabalho em quantidade suficiente para absorver a oferta de mão de obra, o que resultou em um aumento gradativo da taxa de desemprego acompanhada por uma trajetória declinante de rendimentos. 
Com o advento do Plano Real em 1994, houve uma recuperação expressiva nos níveis de rendimento, acompanhada de progresso distributivo, entretanto, não está claro se tais avanços foram suficientes para compensar a deterioração de anos anteriores, pois se faz necessário investimento na geração de empregos e na qualificação de recursos humanos (RAMOS e VIEIRA 2001).

Os esforços de acordo com BARROS (2000), devem ser no sentido de reduzir o grau de pobreza levando em consideração a estabilidade dos últimos anos.

Diante disso, desenvolvimento humano traduzido em qualidade de vida é a prerrogativa de gozar de direitos inerentes à cidadania, liberdades e oportunidades, fundadas no auto-respeito e satisfação das necessidades individuais e coletivas para alcançar felicidade.

Qualidade de vida, na Carta de Otawa é um objetivo a ser alcançado pela promoção da saúde através da capacitação, participação e controle desse processo pela comunidade (MS 2001).

Qualidade de vida boa ou excelente é aquela que ofereça o mínimo de condições para que os indivíduos nela inseridos possam desenvolver o máximo de potencialidades, sejam estas: viver, sentir ou amar, trabalhar produzindo bens e serviços, fazendo ciências ou artes. Com uma noção eminentemente humana, tem sido aproximada ao grau de satisfação encontrado na vida familiar, amorosa e ambiental e até a própria estética existencial (MINAYO et al. 2000; RUFINO NETO 1994).

Qualidade de vida estabelece uma relação direta com as concepções de saúde e doença, sob a influencia de múltiplos fatores tratados a seguir.

\subsubsection{Concepções de Saúde e Doença}

A evolução da concepção de saúde e doença leva, ao fortalecimento da teoria da sua multicausalidade, sob influencia de fatores biológicos, ambientais, estilos de vida e acesso aos sistemas de saúde, mas, sobretudo, à concepção de que tais fatores não são estáticos e mantêm uma relação direta com gradientes de qualidade de vida, que podem ser medidos por indicadores de saúde e, daí, se poder traduzir o conceito de saúde como qualidade de vida, um direito de cidadania. 
Essa concepção, que reflete a evolução da saúde pública, integra o documento balizador da promoção da saúde, a Declaração de Alma-Ata (1978), que, além de reafirmar o conceito de saúde como qualidade de vida, indica a estratégia dos cuidados primários de saúde, proporcionando serviços de promoção, prevenção, cura e reabilitação, sugerindo a intersetorialidade como o meio mais eficaz de atingi-lo.

De acordo com a Declaração de Alma-Ata (1978), só será possível atingir a meta da "saúde para todos", especialmente nos países em desenvolvimento, com progresso econômico e medidas de combate à pobreza, produção de alimentos, abastecimento de água, saneamento básico, proteção ambiental e educação. Essas medidas poderão também contribuir para a meta de desenvolvimento humano.

Em 1995, a Organização Mundial da Saúde, durante a 48ª Assembléia Mundial da Saúde, avaliou os benefícios colhidos, refletidos na redução dos indicadores de morbi-mortalidade, naquelas nações que implementaram os Cuidados Primários de Saúde. Reconheceu, entretanto, que a proposta Saúde Para Todos no ano 2000, se deu num período de recessão econômica, em que as políticas de ajuste estrutural de países em desenvolvimento contribuíram, de forma significativa, para acentuar as desigualdades dentro e fora dos países.

Diante dessa avaliação, reafirma-se a validade de Saúde para Todos como objetivo permanente e concita todas as organizações e populações a colaborarem na identificação das condições de saúde e implementação de novas estratégias nos próximos 25 anos (OMS 1995).

A evolução da concepção sobre saúde e doença vai desde a teoria mística em que a doença se apresentava como fenômeno sobrenatural, passando ao conceito de saúde ideal, de acordo com a Organização Mundial da Saúde (OMS), segundo o qual, saúde é um estado de completo bem estar físico, mental e social, e não a mera ausência de moléstia ou enfermidade; até a concepção atual em que o processo saúde - doença se constitui em uma expressão particular do processo de vida social considerando-se, portanto, um fenômeno determinado e/ou condicionado a um processo causal, daí se dizer que há uma "produção social da doença" (BREILH 1990).

Contra a concepção mítica do mundo, inclusive do mal que se traduz em enfermidade, a teoria dos humores inaugura o que, por muitos, é tida como o 
nascimento da medicina científica. A idéia mestra é de harmonia dos quatro elementos fundamentais da natureza: terra, fogo, ar e água, as quatro estações e qualidades: quente, frio, úmido e seco e os quatro "humores" constituintes do vivo, especialmente humano: bile, negra e amarela, fleuma e sangue. Equilibrados os humores, cada qual na proporção justa, o estado é dito de saúde. A doença vem a ser o desequilibrio humoral causado por fatores externos (ar, clima, alimentos, bebidas) e internos ("constituição", excesso e predominância de um humor sobre os outros) (ROSEN 1994).

Entretanto, a saúde adquire maior relevância com o advento da industrialização e, conseqüentemente, com o processo de urbanização tão bem ilustrado por ROSEN (1994). Em seu estudo sobre o industrialismo e movimento sanitário, enfocam-se três teorias para explicar a evolução das concepções de saúde e doença. Primeiro, a teoria miasmática, em que a doença era causada pela atmosfera e, para enfrentá-la se deveria investir no saneamento ambiental; a segunda teoria estabelecia uma visão de serem os contágios específicos as únicas causas de infecções e de doenças epidêmicas, reforçadas pelo grande impacto causado pelas descobertas bacteriológicas do século passado e a terceira teoria era a conciliação entre a teoria miasmática e a contagiocionista.

Com o advento do capitalismo, já com a consolidação da era bacteriológica, Resende (1986) citado por SANTANA (1998), enfoca quatro teorias para explicar a gênese das patologias:

- a teoria unicausal - em que a doença tem uma única causa. A atuação do agente causador da doença dá-se independente do controle do organismo ou dos aspectos sociais que envolve a pessoa;

- a teoria da multicausalidade - o processo saúde doença é visto sob a determinação de múltiplos fatores, porém sem explicação sobre a atuação desses fatores;

- a teoria de Leavell-Clarck - explica o fenômeno saúde - doença como um processo dinâmico e pressupõe que a saúde é encontrada no equilíbrio entre os três elementos - o homem, o agente e o meio ambiente - e que o desequilíbrio, em qualquer um desses elementos, determinaria a doença; 
- e a teoria da epidemiologia social que de acordo com LAURELL (1982), deve ser considerado o caráter histórico da doença e que a natureza social desta não se verifica apenas como um caso clínico, mas, relacionado com a forma de adoecer e morrer das pessoas.

Para CASTELLANOS (1997), mais relevante do que o conhecimento sobre as causas da morte seria conhecer como as pessoas vivem e com que idade morrem.

No processo evolutivo do conceito de saúde, a causalidade única atingiu grande expressão com o advento da era bacteriológica, sobrepondo, freqüentemente, as causas relacionadas com o hospedeiro e o meio ambiente, no entusiasmo pelo isolamento de agentes vivos específicos.

Em uma abordagem mais dinâmica do que aquela apresentada pela OMS, Perkins, citado por LEAVELL e CLARCK (1978), diz que "saúde é um relativo equilíbrio de forma e função do organismo, que resulta do seu ajustamento dinâmico satisfatório às forças que tendem à perturbá-lo", atribuindo à saúde e à doença diferentes graus.

O conceito da causalidade múltipla, de acordo com LEAVELL e CLARK (1978), está associado à história natural da doença, considerando o afastamento progressivo da saúde em direção à doença, incapacidade, invalidez ou morte, para o qual constrói um esquema, relacionando a história natural da doença ao período de pré-patogênese e período de patogênese, de acordo com a aplicação dos níveis de prevenção primária, secundária e terciária.

A epidemiologia se vincula à saúde pública no século XIX quando os movimentos emergentes se contrapõem à corrente contagicionista, e atribuem as doenças à pobreza das maiorias, destacando-se Virchouw na Alemanha, Villermé na França e Alisson na Escócia (CASTELLANOS 1997).

A teoria da epidemiologia social (LAURELL (1982); BREILH (1986), enfoca a saúde - doença como um processo social, biológico e histórico, rompendo com a relação causa e efeito.

As concepções do processo saúde e doença de acordo com LEAVELL e KLARCK (1988), e a evolução desse conceito, no sentido da produção social da saúde-doença (LAURELL 1982; BREILH 1986; CASTELLANOS 1997), evidenciam a influência de múltiplos fatores na determinação da doença como estilo 
de vida, biologia humana, ambiente físico e social e serviços de saúde considerados no relatório Lalonde (1974), fortalecendo as bases da promoção da saúde e do movimento por cidades saudáveis.

\subsubsection{Promoção da Saúde e o Movimento por Cidades Saudáveis}

A preocupação com a qualidade de vida nas cidades não é um fato recente, pois Aristóteles, na Grécia antiga, já enunciava estudos urbanos, e insistia, sabiamente, que deveríamos ver a cidade com os nossos próprios olhos, de maneira simpática, numa visão global, tendo, nessa época, elaborado um estudo para comparar as estruturas urbanas de 163 cidades (GEDDES 1994).

$\mathrm{O}$ autor refere ainda que, na Idade Média, os espaços públicos das cidades, tal como os mercados, jardins e vias públicas, eram amplos. Entretanto, com o advento da industrialização, o espaço urbano vai se deteriorando, chegando ao seu período mais crítico na Segunda Revolução Industrial, como revelam os relatos de ENGELS (1975), ao descrever a caótica situação da classe trabalhadora na Inglaterra, no início do século XIX.

Os estudos e intervenções de Chadwick, citado por ROSEN (1994), representam também valiosos documentos, pois foi o autor que mais contribuiu com o primeiro relatório da Comissão de Saúde das Cidades, bem como das proposições administrativas e operacionais. A Comissão mostrava que superpopulação, pobreza, criminalidade, insalubridade e mortalidade alta conviviam entre si.

A preocupação com a qualidade de vida nas cidades surge a partir da concentração das populações nos grandes centros e, com ela, as condições de habitação, de trabalho, de alimentação e de saneamento básico, que, interferindo nas condições de saúde e doença das pessoas, tem reflexo direto na produtividade das fábricas. Com os estudos de Chadwick, e a evolução das concepções e controvérsias sobre a origem e transmissão das doenças, nasce a organização internacional da saúde, sendo considerada por ROSEN (1994); CASTELLANOS (1997) como o início da saúde pública.

A Organização Mundial de Saúde, juntamente com a Organização Pan-Americana de Saúde, especialmente na segunda metade do século XX, vem promovendo eventos 
no sentido de chamar a atenção para os problemas de saúde coletiva, como as Reuniões de Ministros da América e as Conferências Internacionais de Saúde, se configurando a Conferência Internacional sobre Cuidados Primários de Saúde reunida, em Alma-Ata, em setembro de 1978, um marco para desencadeamento do movimento por cidades saudáveis.

O movimento por cidades saudáveis se fortalece no Canadá, na década de 1980, a partir do Encontro sobre Cidades Saudáveis em Toronto, em 1984, para o qual muitos países foram convidados a participar das discussões (LEE 1984) e a Primeira Conferência Internacional sobre Promoção da Saúde em 1986, que gerou a Carta de Otawa com grande repercussão no mundo inteiro.

$\mathrm{Na}$ década de 1990, o movimento por cidades saudáveis expande-se na América Latina com o apoio da Organização Pan-Americana de Saúde (OPAS). Em 1991, têm início, em São Paulo, as negociações para implementação do convênio de cooperação técnica entre as cidades de São Paulo e Toronto, e já em 1994 e 1995, dez cidades de São Paulo, uma cidade da Bahia, quatro cidades do Paraná e uma de Alagoas incluem, em suas agendas políticas, projetos na perspectiva do ideário de cidades saudáveis com a implementação de políticas públicas que incorporassem pressupostos de intersetorialidade, participação social e saúde como qualidade de vida (MENDES R 2000).

Em 1996 o Movimento por Cidades Saudáveis no Brasil, conta com a participação de Universidades, do CONASEMS (Conselho Nacional de Secretários Municipais de Saúde) e da Fundação Kellogg com a participação de Vargem Grande Paulista em São Paulo; Sobral, Crateús e Fortaleza no Ceará; Anadia, Arapiraca e Flexeiras em Alagoas; Dionísio e São José do Goiabal em Minas Gerais (MENDES R 2000).

Uma das experiências mais recente é a implementação do projeto Cidade Saudável em Bertioga - São Paulo e a manutenção do Centro de estudos, pesquisa e documentação (CEPEDOC), com a intenção de estimular a formulação e o aprofundamento teórico e conceitual relacionado ao tema sob a coordenação (WESTPHAL 2000).

Inspirada na Declaração de Alma-Ata, a Carta de Otawa desencadeou outros eventos similares, como a Declaração de Adelaide, na Austrália em 1988, a Declaração de Sundsvall, na Suécia em 1991 e a Declaração de Bogotá em Santa Fé 
de Bogotá, Colômbia, em 1992. Nesta última, entre os representantes de 21 nações, estava a maioria dos países latino americanos. No evento foi discutido a promoção da Saúde na América Latina, marcada pela iniqüidade, agravada pela grave crise econômica e pelos programas de ajuste macroeconômico, o que vem contribuindo, de forma significativa, na deterioração das condições de vida da maioria da população. Em seguida, foi elaborada a declaração de Jacarta, durante a Quarta Conferência Internacional de Saúde, em 1997; o surgimento da Rede de Mega Países para a Promoção da Saúde em Genebra, no ano de 1998 e a Declaração do México, realizada durante a Quinta Conferência Internacional sobre Promoção da Saúde, no ano 2000 (MS 2001).

O evento mais recente foi realizado pela Organização das Nações Unidas (ONU), em Joanesburgo, África do Sul, chamada de Rio mais dez, realizado dez anos depois da ECO 92, no Rio de Janeiro, tendo a participação de representante de 195 países, inclusive do Brasil, (PACHECO 2002).

A partir desses eventos, forma-se uma rede de cidades saudáveis, que se estende pela Europa em mais de 1000 cidades, pela América do Norte, especialmente Canadá e Estados Unidos. Na América Latina, começa a se desenvolver essa Rede, na década de 90 e, desde então, notou-se que as experiências são bastante diversificadas, de acordo com suas características políticas, econômicas e sociais de cada país.

No Brasil, talvez o evento mais significativo na área de saúde, como desdobramento imediato da Declaração de Alma-Ata, em 1978, tenha sido a criação do PREV-SAÚDE, Programa Nacional de Serviços Básicos de Saúde, durante a VII Conferência Nacional de Saúde em 1980, o qual não chegou a ser operacionalizado.

Em 1986, no mesmo ano em que se realizou a Primeira Conferência Internacional da Saúde em Ottawa - Canadá, aconteceu, no Brasil, a VIII Conferência Nacional de Saúde, o evento de maior mobilização política na área de saúde, promovido pelo Movimento da Reforma Sanitária Brasileira, num período que coincide com o processo de redemocratização do país na luta pelas eleições diretas.

No âmbito das práticas sanitárias, a implantação de Sistemas Locais de Saúde (SILOS) foi amplamente defendido por MENDES EV $(1993,1996)$ na década de oitenta. Na década de noventa, o mesmo autor propõe a integração entre a proposta de SILOS, como estratégia operacional dos serviços de saúde, e o projeto de Cidades 
Saudáveis, como estruturante para resolver os problemas de saúde no Brasil, ambos voltados para a melhoria da qualidade de vida da população

Na Bahia, há um avanço democrático no percurso do Sistema Único de Saúde influenciada pela capacidade e compromisso dos dirigentes com o iderário da reforma sanitária, tendo reflexo nos espaços de poder do Secretário Municipal de Saúde. É o que se observa com a eleição do governo pelo Estado em 1986 com experiências de trabalho desenvolvido anteriormente no Ministério da Previdência Social. Nesse contexto o governo assume as Ações Integradas de Saúde e o Sistema Unificado e Descentralizado de Saúde como principais estratégias para implementação da reforma sanitária no Estado (PAIM 1988).

Entretanto, há um retrocesso no processo de implementação do sistema de saúde, com a transição do governo, e a demissão de lideranças do INAMPS, naquela época, agravado ainda pela instabilidade do financiamento da saúde na perspectiva da reforma sanitária de construção de um sistema público resolutivo.

MENDES R. (2000), afirma que os antecedentes mais próximos do projeto por cidades saudáveis, na América Latina, foram os projetos de SILOS. Acrescente-se a isso que a busca de equidade da atenção, universalidade do acesso, integralidade das ações, com base na participação social, estavam embutidas na proposta de SILOS, como parte do ideário da Reforma Sanitária que deu origem ao - Sistema Único de Saúde.

A proposta de Curitiba - "Saudicidade" que tem origem na década de 1970, apresenta-se como um dos melhores exemplos de cidade saudável a partir da organização do sistema local de saúde (SILOS) (SILVA JUNIOR 1998).

O alcance da promoção da saúde no movimento por Cidades Saudáveis está alicerçada pela participação social, na luta pelos direitos de cidadania e pelo desenvolvimento sustentável dos municípios.

\subsection{Cidadania}

A concepção histórica da cidadania se fundamenta nos estudos de Marshall citado por ANDRADE (1993) em que não configura a cidadania apenas como uma condição legal, estática e definitiva, mas sim como um processo de conquista. 
Marshall classifica a cidadania em três elementos constitutivos: civil, político e social. Nessa sequiencia os direitos de cidadania foram sendo incorporados aos direitos do cidadão. Os direitos civis incluem a liberdade de ir e vir, liberdade de imprensa, pensamento e fé, direito à propriedade e de concluir contratos e o direito à justiça. Esses direitos são conquistados no século XVIII, coincidindo com o início da revolução industrial. Os direitos políticos que significam a participação no poder política como o direito de votar para escolher governantes e o direito de exercer cargos públicos, esses direitos são conquistados, parcialmente, no século XIX com base na conquista dos direitos civis. Os sociais, que se configura como direitos de gozar de padrões de vida que prevalecem na sociedade, incluído aí os serviços sociais e escolas. Esses direitos passam a ser incorporado a vida das pessoas, nos países desenvolvidos, no século XX após a Segunda Guerra Mundial (ANDRADE 1993).

A capacitação da comunidade para participar das decisões referentes aos seus deveres e direitos, pode ser traduzida na incorporação dos direitos de cidadania que, segundo COHN (1997) BENEVIDES (1996), pode ser enfocada de duas formas, cidadania passiva, outorgada pelo Estado em que a pessoa é considerada como cliente, consumidor e contribuinte e a cidadania ativa, em que a pessoa conquista novos espaços e novos direitos, dispondo e utilizando, adequadamente, dos direitos que lhe são outorgados pelo Estado.

A concepção de cidadania e de direitos do cidadão têm raízes na revolução francesa e na teoria constitucional moderna, segundo as quais o indivíduo tem vínculo com o Estado, e direitos dos cidadãos, que em tese, são iguais perante a lei, porém, subordinados ao Estado (BENEVIDES 1994).

$\mathrm{O}$ autor refere que, no quadro das democracias liberais, cidadania corresponde ao conjunto das liberdades individuais e evoluem, na democracia social para os direitos trabalhistas e de prestação de serviços de natureza social, reclamados ao Estado, como educação, saúde, seguridade e previdência.

Cidadania se define pelos princípios de democracia, significando um processo de conquistas e a consolidação de políticas. Cidadania ativa implica em complementaridade entre a representação política tradicional e a participação popular exercida diretamente (CHAUÍ citado por BENEVIDES 1996). E também se traduz 
por maior participação política na qual se inclui a institucionalização dos mecanismos de democracia semi-direta.

COHN (1995), discute que as políticas públicas tanto podem ser implantadas como direito do cidadão, como podem ser formuladas como conseqüência da luta por mais cidadania. Os direitos de cidadania definem-se pelo princípio da democracia, exigindo instituições e comportamentos próprios, espaços sociais de lutas e definição de instituições permanentes para expressão política.

A participação, como controle social, como o exercício da cidadania ativa pode apresentar duas dimensões: accountability - a obrigação dos dirigentes políticos de prestarem contas dos seus atos e decisões, e o direito conferido ao cidadão de exigir e avaliar a responsabilização dos agentes políticos pelos atos praticados em nome da sociedade conforme padrões éticos e legais estabelecidos (TEIXEIRA EC 2000).

O controle social do Estado, em suas decisões estratégicas e econômicas, pode ser exercido através de centros periféricos do poder como os conselhos. Controlar o Estado implica na correção de desvios e na responsabilização dos agentes políticos. Isso requer organização da sociedade civil, antes e durante a implementação de políticas (TEIXEIRA EC 2000). Para BOBBIO (1983), o alargamento do controle dos centros de poder é essencial ao desenvolvimento democrático.

Numa análise retrospectiva da política no Brasil retoma-se o ano de 1946 quando foi promulgada a Constituição que vigorou até 1967 e instalou-se um período de redemocratização do País com a disputa entre os progressistas, que desejavam o estabelecimento de uma democracia político-econômica e os conservadores, que defendiam a democracia liberal. Sob o clima da guerra fria, essas disputas políticas envolveram episódios dramáticos, como o suicídio de Getúlio Vargas em 1954 e a vitória dos conservadores, que com o golpe de 1964, assumiram o poder (MOURA 2000).

No período pós 64, segundo COSTA (1988) com a implantação do regime militar prevaleceram as seguintes tendências:

- centralização decisória em nível federal, mediante a desapropriação dos instrumentos de ação social de estados e municípios;

- fragmentação institucional, que possibilitou o bloqueio à participação social e política no processo decisório, com a supressão das formas de controle social; 
- privatização da tomada de decisão por meio da articulação entre a burocracia pública e o empresariado;

- regressividade no padrão de financiamento, centrado nas contribuições dos assalariados;

- fechamento dos canais de acesso da população aos bens e serviços sociais.

As ações sociais, no período de 1964 a 1985, repercutiram de forma marginal sobre o perfil de desigualdade dominante e, também, sobre os indicadores sociais (JACOBI citado por COSTA 1998).

Mesmo em condições adversas, em meados dos anos 70 , um conjunto de atores passa a intervir ativamente, tornando visível as carências das populações de bairros periféricos - igreja e seus agentes pastorais, militantes partidários de esquerda, associações de moradores, clubes de mães e assessores. Algumas lideranças, principalmente aquelas com pouca experiência de luta, se desligavam do movimento ou acabavam incorporados ao poder público através da obtenção de empregos em órgãos da prefeitura (JACOBI 1989).

$O$ autor enfatiza ainda que com a redemocratização do país, os partidos políticos adquiriram presença e competitividade na sociedade (especialmente os partidos de esquerda, grifo da autora), os movimentos sociais perderem parte do dinamismo e visibilidade, indicando que eles têm um ciclo de vida e que ao atingir suas metas imediatas ocorre o fim da mobilização.

Entretanto, quando GOHN (1997), analisa os movimentos sociais contemporâneos e o modelo de desenvolvimento brasileiro nos anos 90, diz que os governantes dão ênfase às políticas sociais mediadas por ajustes estruturais como forma de superação da crise econômica e a retomada do desenvolvimento com uma certa proteção aos grupos vulneráveis ao desemprego e ao subemprego.

Não apenas os ajustes na economia, mas também a discussão em torno da miséria dos indigentes que vem ocupando a agenda dos dirigentes e propostas governamentais internacionais, como a Cúpula Mundial do Desenvolvimento Social realizada em Copenhague em 1995, se deve a "uma conquista dos grupos e movimentos sociais da sociedade civil que se organizaram e lutaram para se tornar sujeitos" (GOHN 1997-p.300). 
A prática da participação social, a exemplo das experiências citadas, de alguma forma rompe com os costumes que, segundo BENEVIDES (1996), marca a sociedade brasileira pelas tradições oligárquicas e patrimonialistas, que se constituem como os maiores obstáculos à legitimação dos instrumentos de participação popular.

A autora coloca ainda, que a introdução do princípio de participação popular no governo como forma de amenizar tais obstáculos e a educação política como condição necessária à cidadania ativa, se traduz em exigência de mais participação.

Várias são as formas de participação e AMMAN (1980), enfoca a concepção gramsciana sobre hegemonia em que os dois componentes do Estado: sociedade política e sociedade civil podem exercer ao se entrecruzarem. A sociedade política corresponde à hegemonia exercida pela força e a sociedade civil pela persuasão que se mediatiza pela conjugação da força e do consenso.

Tanto as colocações de BENEVIDES (1996), defendendo a cultura da participação, ainda sendo construída no Brasil, e de AMMAN (1992) ao buscar o equilíbrio de forças entre a sociedade política e a sociedade civil em todas as manifestações da vida humana, entende-se como forma de fomentar o empoderamento da sociedade.

De acordo com WALLERSTEIN (1992), os efeitos da organização da sociedade melhora o empowerment através de variáveis psicológicas que favorecem a autonomia, a motivação, a credibilidade dos grupos sociais, o fortalecimento das relações sociais e as condições de transformações sociais.

Para pensar na conquista de direito de cidadania, é preciso considerar que, "cada direito requer luta de quem ainda não o exerce. Sem luta, o direito limita-se a uma utopia" (MOURA 1989).

Entende-se, corroborando com WALLERSTEIN (1992), que quanto maior o grau de organização da sociedade maior será o poder que ela exercerá, inclusive na implementação de políticas públicas condizentes com as suas necessidades.

\subsection{Políticas Públicas}

As políticas públicas são instrumentos utilizados pelo Estado para conduzir sua ação com o objetivo de reduzir as diferenças entre as classes sociais e, assim, 
promover o desenvolvimento social. As políticas públicas podem ser conceituadas como a criação de espaços alternativos, capazes de agrupar atividades que contribuam para o enriquecimento da qualidade de vida da população (RAMOS e GARCIA citado por FREITAS et al. 1993).

As políticas públicas são entendidas, ainda, como conseqüência da existência de diversos grupos de interesse presentes na sociedade que, ao atuarem em arenas políticas, influenciam as decisões sobre as políticas públicas, podendo ser consideradas um conjunto de direitos positivos que vinculam o cidadão ao Estado; e, sob esse prisma, a Reforma Sanitária Brasileira (o SUS) é considerada uma particular política de saúde, incluída no campo das políticas sociais (GERSCHMAN 1995; MERHY 1992).

Algumas correntes teóricas estudam a caracterização das políticas sociais, a exemplo da "teoria da divergência", uma variação do modelo funcionalista, referindo-se às políticas sociais como resultantes do desenvolvimento econômico e industrial, em torno do qual a estrutura social, como um todo, se integra funcionalmente (GERSCHMAN 1995).

De acordo com as concepções de OFFE (1998), existem dois planos de análise das políticas sociais: um plano estrutural, com políticas sociais ligadas ao Estado e o plano singular, captado por meio da pesquisa empírica, centrada na evolução, modificação e inovação de uma dada política social e com a implementação de inovações políticas, nas quais os atores políticos são fundamentais para se compreender essas inovações.

As políticas públicas de corte social pertencentes a contextos de desigualdades, peculiares à realidade brasileira, necessitam contemplar novas formas de articulação com a economia política, considerando-se a atual conjuntura, marcada pelo desafio da consolidação de uma ordem democrática no país (COHN 1997). As políticas públicas devem estar comprometidas com o objetivo de melhorar a qualidade de vida da população, como fator imprescindível para superação do quadro de iniqüidade social reinante (BARROS 1994).

Portanto, as políticas públicas de cunho social, no Brasil, enquanto elementos constitutivos da cidadania, de sujeitos sociais coletivos, partem de uma realidade bem diferente daquela vivida pelos países centrais (COHN 1997). O direito à saúde, 
na realidade brasileira, pode ser mais difícil por ela ser entendida como atendimento a condiçōes de natureza biológica, econômica e social, destacando-se, entre elas, nutrição adequada, moradia higiênica, trabalho em ambiente salubre, lazer suficiente, saneamento ambiental, poder aquisitivo de um salário ajustado às necessidades básicas do ser humano, cuja explicitação do direito configura um processo histórico evolutivo, determinado pelo gradativo amadurecimento da consciência das pessoas em relação a seu valor e a suas necessidades biológicas, psíquicas e sociais (MOURA 1989).

As políticas públicas podem sofrer influência das pressões sociais, mas sua efetivação na prática, dependerá, substancialmente, da estrutura de governo e das prioridades da sua agenda, que deverão refletir as reivindicações da sociedade civil organizada.

\subsubsection{Concepções e Reforma de Estado}

O termo Estado foi criado por Maquiavel (Século XV) e representa o poder político que se exerce sobre um território e um conjunto demográfico. No Estado, estão presentes três elementos: poder político, povo e território (GRUPPI 1996). De acordo com DALLARI (2000), "o Estado é uma ordem jurídica que tem por fim o bem comum de um povo situado em determinado território".

O Estado sofreu uma evolução histórica e mantém sua função primordial de assegurar condições gerais de paz social e prosperidade pública, cumprindo-lhe intervir na ordem sócio-econômica, remover injustiças e edificar um mundo melhor onde a felicidade e a justiça sejam uma realidade possível (MALUF 1999).

De acordo com GRAMSCI (1991), Maquiavel defende a necessidade de um Estado que domine as leis como forma de proteger os cidadãos dos golpes do arbítrio, mas ao mesmo tempo, reconduz tudo à política e a arte de governar os homens.

ROUSSEAU, no século XVIII, em seu Discurso sobre as Causas da Desigualdade entre os Homens e Contrato Social, afirma que o Estado é convencional, não há direito divino e o governo é instituído para promover o bem 
comum e só é suportável enquanto justo, devendo ser substituído, se não corresponder aos anseios do povo (MALUF 1999).

TESTA (1992) diz que o Estado é um espaço social composto pela integração de instituições e no seu interior se busca a definição da democracia.

Mesmo obedecendo à concepção de que a democracia é o governo da maioria, historicamente o corpo eleitoral é formado pelos cidadãos, por aqueles que, reunindo as qualidades exigidas na lei, exercem os chamados direitos políticos ou direitos de cidadania. A Democracia, no sentido formal, é um sistema de organização política em que a direção geral dos direitos coletivos compete à maioria do povo, segundo convenções e normas jurídicas que assegurem a participação efetiva dos cidadãos na formação do governo. É o que se traduz na fórmula clássica: todo poder emana do povo e, em seu nome, será exercido (MORAES 2000).

O surgimento do Estado trouxe, em seu bojo, a necessidade de definir sua organização por meio de Constituição Política, mas, somente a partir do século XVIII, em 1791, na França, em decorrência da Revolução de 1789 e nos Estados Unidos da América em 1787, surge o conceito de Lei Constitucional com hierarquia sobre as demais leis (MORAES 2000).

As concepções de Estado estão assinaladas em duas dimensões básicas: o Estado como uma relação social de dominação e o Estado como um conjunto de organizações com autoridade para tomar decisões que atinjam a todos os indivíduos de uma coletividade (PEREIRA JM 1999).

Para o autor, nos séculos XVIII e XIX, a atividade financeira do Estado era caracterizada pelo chamado "Estado-gendarme", que se distinguia pelo princípio da não intervenção do Estado na economia, fundado no entendimento de que as leis financeiras eram imutáveis como as leis científicas. No fim do século XIX, a atividade financeira deixou de refletir o Estado - gendarme para converter-se em instrumento de política social, orientado para as políticas públicas funcionais. Esse novo enfoque passa a predominar e, após a década de 30, a principal característica das políticas públicas passa a ser de caráter intervencionista. As finanças neutras dão lugar às finanças funcionais, direcionadas para influir sobre a conjuntura econômica.

A presença do Estado na economia, medida pela concentração de gastos, incluindo previdência social, nos países desenvolvidos, passa, em média, de $18 \%$ na 
década de 20, para mais de $40 \%$ na década de 80 , segundo Deutch citado por PEREIRA JM (1999).

Há uma crescente intervenção na economia com o objetivo de corrigir desigualdades sociais geradas pela competição do mercado, típico do liberalismo praticado no século XIX e as democracias ocidentais passam a adotar o Estado Providência. A incompatibilidade entre a ideologia liberal do mercado e a estatizante levou à falência das políticas sociais no mundo ocidental e entra em crise o EstadoProvidência. Registra-se que o Brasil não chegou a beneficiar-se dos ganhos positivos obtidos por esse modelo de proteção social (PEREIRA JM 1999; CHAUÍ 1999b).

Nesse quadro de crise, busca-se na Reforma do Estado, as possíveis soluções para diminuir a sua sobrecarga sem perder o controle da "rés pública".

A Reforma do Estado, como foi proposta por HAYEK e FRIEDMAN (1947) citado por CHAUí (1999b), apresenta, como pressuposto básico, o mercado na condição de portador de racionalidade sócio-política e o agente principal do bem estar da república. De acordo com a proposta de reforma, há uma oposição ao Estado de Bem-Estar keynesiano e a política americana New Deal, o que significa um encolhimento do espaço público democrático dos direitos e ampliação do espaço privado. Essas idéias ficam adormecidas até a crise do capitalismo, na década de 1970, marcadas pelas baixas taxas de crescimento econômico e inflação. (CHAUí 1999b).

O modelo foi primeiro aplicado no Chile, depois na Inglaterra e nos Estados Unidos, expandindo-se para todo o mundo capitalista, excetuando-se os países asiáticos e depois da queda do muro de Berlim, para todo o Leste Europeu (CHAUí 1999b).

Na segunda metade da década de 90, segundo GIDDENS (1999), Tony Blair fala sobre a ambição de criar a teoria da sociedade política contemporânea, com a finalidade de buscar um consenso internacional de centro esquerda para organizar a ação política do Século XXI.

Esse mesmo autor apresenta contribuições para um debate sobre o futuro dos princípios político sociais democráticos, encampado como bandeira política de Toni Blair, na Inglaterra, e conclama os sociais democratas a encontrarem uma Terceira 
Via como forma de renovação, tendo como base os seguintes valores: igualdade; proteção aos vulneráveis; liberdade como autonomia; não há direito sem responsabilidade; não há autoridade sem democracia, pluralidade cosmopolita e conservadorismo filosófico. Fundamenta essas suas propostas nas seguintes razões: dissolução do consenso do "welfare state" que vigorou em países industrializados até o final da década de 70; aposta na sobrevivência da social democracia que pode prosperar para além do nível ideológico, avançando no nível prático.

PEREIRA LCB (1999) refere que pela primeira vez, a esquerda desenvolvia, de forma sistemática, um programa coerente com a nova esquerda sem negar as diferenças entre direita e esquerda. A Nova Esquerda, representando o Novo Trabalhismo e a Terceira Via liderado por Tony Blair, sob a concepção teórica de intelectuais, como Antony Giddens, assume a disposição de arriscar a ordem em nome da justiça, enquanto que a direita continua a priorizar a ordem em relação à justiça, ainda que não se pretenda eliminar a universalidade da educação básica e da saúde que devem ser financiadas pelo Estado, mas propõe que a prestação de serviços seja feita, cada vez mais por entidades públicas não estatais.

Os estudos de SOUZA e CARVALHO (1999), inspirados em HEREDIA e SCHNEIDER (s.d.) indicam que nos países em desenvolvimento, a Reforma de Estado apresenta peculiaridades específicas, que indicam três paradigmas, como proposta de soluções para os seus problemas: escolha pública de prioridades, governo empreendedor e o novo gerencialismo público. México e Brasil assumem mais um caráter gerencialista, Leste Europeu e Argentina são mais voltados para os servidores civis enquanto Chile, Tailândia e Coréia do Sul enfatizam a democratização.

A Reforma do Estado é um fenômeno que chega ao Brasil na década de 1990, após a estagnação econômica da década de 1980, período de luta pela redemocratização do País, após vinte anos de governo militar.

A Reforma do Estado brasileiro apresenta quatro elementos distintos e interdependentes: a definição do tamanho do Estado; desregulamentação; elevação da capacidade financeira do Estado de formular e implantar políticas públicas; e realização de esforços, visando à legitimidade política para implementar reformas (PEREIRA JM 1999). 
O Plano Diretor da Reforma do Aparelho de Estado (MARE 1995) apresenta-se como forma de enfrentar a crise de Estado que o País vinha sofrendo nos últimos 20 anos, e que se define como crise fiscal - caracterizada pela crescente perda de crédito e pela poupança negativa, pelo esgotamento da estratégia estatizante de intervenção estatal, estratégia de substituição das importações e superação da administração pública burocrática.

Reformar o aparelho de Estado significa transferir para o setor privado as atividades que podem ser controladas pelo mercado, promovendo a descentralização, transferindo para o setor público não-estatal a execução de serviços que não envolvem o exercício do poder do Estado, mas devem ser subsidiadas pelo mesmo, como é o caso dos serviços de educação e saúde, cultura e pesquisa científica, pelo processo chamado "publicização"do espaço social.

Entre outras medidas, a reforma do Estado propõe a reforma do aparelho de Estado, com vistas a aumentar sua governança, ou seja, sua capacidade de implementar, de forma eficiente, as políticas públicas.

Para o Ministério da Administração Federal e Reforma do Estado, vários serão os ganhos da sociedade com a Reforma: terá uma administração pública eficiente; equilíbrio das contas nos Estados e Municípios; retomada do desenvolvimento econômico e prestação de serviços públicos de qualidade (MARE 1995).

Recentes avaliações políticas e científicas apontam para uma possibilidade de relativo equilíbrio social, com base no paradigma emergente apresentado por SANTOS BS (1998, 1999): a transformação social da modernidade como a revolução e o reformismo, sendo o primeiro para ser exercido contra o Estado e o segundo a ser exercido pelo Estado através das estratégias de acumulação, confiança e legitimação.

Assim, é animador pensar na nova utopia projetada para o futuro do Estado, o qual, segundo FRANCO (1998), será socialmente controlado e o mercado socialmente orientado em uma sociedade autonomamente organizada, que conquistará, de forma gradativa, sua própria sustentabilidade nos marcos de um novo contrato social e natural. O movimento em direção a esse futuro desejável pode ser realizado a partir da radicalização da democracia, da universalização da cidadania. 
No entanto, um dos limites encontrados no Estado refere-se à diminuição da ação social, na perspectiva neoliberal, que emerge do "Consenso de Washington" e de uma sociedade com necessidades cada vez maiores, em que o terceiro setor poderá abrir a possibilidade de um novo contrato social, embora com algumas ressalvas aos exageros impostos ao processo de globalização, em que os Estados estariam indefesos diante de processos globais incontroláveis, cuja afirmação é considerada um mito (BATISTA JR 1998).

O Terceiro Setor abrange todas as organizações que não pertencem ao Estado ou ao Mercado, incluindo-se aí as entidades beneficentes e assistenciais, as entidades culturais, científicas, educacionais, recreativas, esportivas e ligadas a religiões, igrejas ou assemelhados. Ainda são incluídas, no terceiro setor, as organizações de caráter corporativo e entidades representativas patronais e profissionais, organizações de defesa ou promoção de interesses e direitos gerais difusos, as organizações de religiosos e as organizações políticas de caráter partidário.

O Terceiro Setor apresenta-se de modo diferenciado nas diversas localidades, ao formar o tripé da governabilidade social na composição: Estado, Mercado e Terceiro Setor. Nessa perspectiva, concordamos com DOWBOR (1998), quando declara que é preciso melhorar, radicalmente, a relação entre Estado, Mercado e Terceiro Setor que é gravada pela ausência de instrumentos de regulação da economia global, a qual acentua, cada vez mais, a distância entre ricos e pobres.

Com relação ao Terceiro Setor, SANTOS BS (1998) conserva uma postura crítica, ao diferenciar como este é inserido nos contextos dos países centrais e dos países periféricos e semi-periféricos. Nos primeiros, o Terceiro Setor surge ligado à crise do Estado-Providência, a partir das organizações sociais e políticas progressistas, em defesa da administração pública do Estado por elas contestadas anteriormente. Nos países periféricos e semi-periféricos, o referido autor chama a atenção para o risco de o Terceiro Setor ser chamado a ressurgir, não pelo próprio mérito dos valores inerentes aos princípios de comunidade de cooperação, solidariedade, equidade e democracia interna, mas para atuar como amortecedores de tensões, decorrentes dos ataques neoliberais às conquistas políticas.

O Terceiro Setor está sujeito aos mesmos vícios, hoje atribuídos ao Estado. Entretanto, tais críticas não minimizam as potencialidades do terceiro setor na 
construção de uma regulação social e política mais solidária e participativa. $O$ terceiro setor, nos países periféricos e semi-periféricos, sobressai na década de setenta, com o objetivo de prover serviços básicos, que o Estado não está e, muitas vezes, nunca esteve em condições de prestar (LAWRENCE 1998).

A comissão Regional de Poder Local, Democracia e Desenvolvimento (1995) adverte que a lógica de descentralização, proposta na reforma do Estado, em nome da democratização, pode equivocadamente transferir para a sociedade civil funções que são de responsabilidade do Estado, mesmo defendendo a descentralização como alternativa para aprofundar a democracia e favorecer a formação de atores sociais e ativar os movimentos de cidadania em torno de projetos e desenvolvimentos locais.

\subsubsection{Financiamento das Políticas Públicas}

A atividade financeira do Estado consiste em obter (receita pública), criar (crédito público) gerir (orçamento público) e despender (despesa pública) o dinheiro indispensável às necessidades, cuja satisfação está sob a sua responsabilidade ou é transferida a outras pessoas jurídicas de direito público (PEREIRA JM 1999).

Historicamente, a atividade de financiamento tem sido ignorada pelos órgãos públicos como se isso não fizesse parte de suas responsabilidades. O gerente financeiro, além de se preocupar com a obtenção e alocação de recursos, deve desenvolver três atividades estratégicas: planejamento, controle e avaliação. Planejamento consiste na definição de atividades, identificação de recursos; controle é o acompanhamento das atividades desenvolvidas a comparação com aquelas planejadas e corrigir problemas na execução; e a avaliação se faz através da verificação se as metas estão sendo cumpridas e desenvolvidas em condições adequadas (COUTTOLENC e ZUCCHI 1998).

De acordo com os autores supra citados, para se elaborar uma previsão e programação financeira institui-se a técnica de orçamento, a partir do objetivo e dos meios disponíveis. O orçamento é um instrumento dinâmico, sujeito a revisões constantes durante o exercício financeiro.

O processo orçamentário público é regulado pela Lei Federal 4.320, de março de 1964, que estabelece normas gerais para elaboração e controle dos orçamentos 
públicos, tendo como instrumento de planejamento financeiro e operacional o orçamento-programa. Essa modalidade de orçamento permite o detalhamento da alocação de recursos e o mecanismo de repasse de recursos entre os diversos níveis de governo (COUTTOLENC e ZUCCHI 1998).

Conquanto instrumento de planejamento e expressão financeira das políticas públicas a serem implementadas no município de Feira de Santana, onde se localiza o presente trabalho, a Lei Orgânica do Município, em seu artigo 104, e com base no artigo 165 da Constituição Federal, determina que o poder executivo local estabelece:

I - o plano plurianual;

II- as diretrizes orçamentárias;

III- os orçamentos anuais.

A Lei Orgânica estabelece ainda que, no plano plurianual, deverão constar as diretrizes, objetivos e metas da administração pública por distritos, bairros e regiões, as diretrizes orçamentárias deverão conter as prioridades e metas da administração pública municipal, que orientará a elaboração da lei orçamentária anual, a qual terá entre suas funções, a de reduzir as desigualdades entre distritos, bairros e regiões, segundo critério populacional (GIACOMONI 2001).

A elaboração do orçamento compreende sete etapas:

- fixação dos objetivos técnicos e financeiros;

- programação das atividades com previsão de recursos físicos, humanos e financeiros;

- elaboração da proposta final de orçamento com demonstração financeira projetada e especificação da origem dos recursos;

- discussão e aprovação do orçamento (votado no legislativo e aprovado no executivo);

- execução do orçamento com acompanhamento e controle;

- controle e avaliação com ajuste, se necessário;

- prestação de contas aos órgãos encarregados (COUTTOLENC e ZUCCHI 1998). 
Além das questões técnicas que delimitam a gestão do orçamento público, a conjuntura política e econômica representam o maior determinante do financiamento das políticas públicas.

No Brasil, na segunda metade da década de 70 , o processo de descentralização se identificava com o processo de democratização, sendo consolidado com a Constituição Federal de 1988, que amplia as competências dos Estados e Municípios, visando à nova distribuição de encargos, porém sem um projeto claro da transição (OLIVEIRA FA 1999).

Aliado ao processo político de redemocratização do País, a crise econômica e os planos de estabilização que se seguiram nas décadas de 80 e 90 , tiveram grande impacto sobre os gastos públicos. Por um lado, levam à redução da arrecadação do Estado com a conseqüente diminuição da capacidade de financiamento das demandas sociais aumentadas pelo empobrecimento da população; por outro lado, os programas de estabilização econômica que tinham como objetivo a redução do déficit público, levavam o governo a reduzir, ainda mais, o gasto público (COUTTOLENC e ZUCCHI 1998).

Em 1995, o gasto social público atingiu 20,46 \% do PIB, patamar mais elevado do que na década de 80 , considerado alto para o contexto de início de implementação do Plano Real (plano de estabilização econômica), com um crescimento de $4 \%$ em relação a 1994. Entretanto, os investimentos, na área social, não ocorreram de forma homogênea. Houve maior aplicação em Previdência Social, Trabalho e Organização Agrária. Outras áreas como Educação, Cultura e Desporto, e Transporte Urbano de Massa, se mantiveram estáveis, ao passo que houve redução nas áreas de saúde, saneamento, habitação e urbanismo (OLIVEIRA FA 1999).

O processo de descentralização, que se encontrava caótico no início da década de 90, ganha melhor ordenamento após o plano de estabilização, em 1994, acompanhado de mudanças importantes na priorização do gasto público nas áreas de saúde, nas quais os cuidados primários de saúde começam a receber mais atenção e educação, passando a ser o ensino básico a ênfase maior (OLIVEIRA FA 1999).

Em 1994, diante dos graves problemas de financiamento da saúde, a saída encontrada foi a CPMF (Contribuição Provisória sobre Movimentação Financeira), com a proposta que fosse diretamente destinados à saúde e recolhidos aos cofres do 
Fundo Nacional de Saúde. Após dois anos de luta e discussão, essa lei foi aprovada, em 1996 para ser cobrada a partir de 1997, com alguns equívocos, segundo CARVALHO (2002), tais como:

- esses recursos, por não terem especificação de aplicação seriam perdidos no meio de outros;

- foram constituídos débitos nos anos de 1995 e 1996 antes da arrecadação;

- apenas $21 \%$ dos recursos da CPMF serão utilizados em prevenção.

$\mathrm{Na}$ área de Educação, só em 1995, tem início, no Brasil, a redefinição do papel do Governo Federal na estruturação federativa brasileira e, particularmente, no sistema educacional do país (OLIVEIRA FA 1999).

A aprovação da Lei $N^{\circ} 9.394$ de 20 de dezembro de 1996 que dispõe sobre as Diretrizes e Bases da Educação, abre novas perspectivas para o avanço da descentralização, ao estabelecer contornos mais claros no tocante à responsabilidade das distintas esferas governamentais na oferta de serviços.

Em 24 de dezembro de 1996, foi aprovada a Lei 9.424 que dispõe sobre o Fundo de Manutenção e Desenvolvimento do Ensino Fundamental e de Valorização do Magistério (FUNDEF), que entrou em vigor em janeiro de 1998, um ano depois de sua previsão inicial. Esta Lei, além de designar as fontes de arrecadação para a educação fundamental, especifica os percentuais de aplicação dos recursos arrecadados, sendo $60 \%$ para a folha de salários dos professores da rede pública e 40 \% para a cobertura dos demais gastos como obras, construção e reformas, realização de pesquisas, apoio financeiro em forma de concessão de bolsas de estudo a alunos de escolas públicas ou privadas, serviços destinados aos alunos, como a manutenção de transporte escolar.

Desde o ano de 1998, está vigorando o repasse de $\mathrm{R} \$ 315,00$ por aluno matriculado, como valor médio por estados e municípios. Esse valor mínimo, definido nacionalmente, deverá ser complementado pela União, sempre que o bolo formado com os $15 \%$ do Imposto de Circulação de Mercadorias (ICMS), do Fundo de Participação dos Municípios (FPM), do Fundo de Participação dos Estados (FPE) e do Imposto de Produtos Industrializados (IPI), Exportação dos Estados e Municípios não sejam suficientes para compor esse valor. 
A Lei No 9.394 prevê ainda, que o Município continua obrigado a aplicar $25 \%$ da arrecadação dos impostos em favor da manutenção e desenvolvimento do ensino. Desse percentual, $60 \%$ deverão ser aplicados no ensino fundamental por força do disposto no artigo 60 do Ato das Disposições Transitórias da Constituição de 1988.

A contabilização e prestação de contas são feitas com base na programação orçamentária da despesa, sob o controle do Conselho Municipal de Acompanhamento e Controle Social que acompanha e avalia a aplicação do Fundo.

Ainda como forma de incentivar as famílias carentes a manter os filhos na escola e contribuir com as despesas foi criado um projeto bolsa escola, para oferecer benefícios, que para serem recebidos devem obedecer a determinados requisitos a serem apresentados pela família: ter renda mínima percapita inferior a meio salário mínimo; ter filhos dependentes menores de 14 anos; comprovar matrícula com frequiência de todas as crianças em escolas públicas ou em programas de educação especial.

Para a área da saúde a Emenda Constitucional 29 de 13 de setembro de 2000 e as transferências fundo a fundo visam manter o fluxo ode financiamento para os municípios no sentido de viabilizar o Sistema Único de Saúde.

A Emenda 29 prevê a aplicação do mínimo de $7 \%$ da receita proveniente de impostos para o ano 2000 até atingir $15 \%$ em 2004.

É inegável a importância de assegurar os recursos para financiamento do sistema de saúde, porém o acesso da população aos serviços será atingido com universalidade e integralidade somente se os gestores de saúde estabelecerem prioridades para intervir e organizar as redes de assistência, obedecendo, tanto a lógica políticoadministrativa de delimitação do sistema local de saúde, como a capacidade técnicaoperacional necessária ao exercício das funções de alocação de recursos, programação, regulação do acesso, controle e avaliação do sistema de saúde (SÃO PAULO 2000).

Para área de meio ambiente ainda não existe um arcabouço jurídico-institucional estabelecendo uma política Estadual de Saneamento embora, esteja previsto nas Constituições Federal e Estadual (MORAES 2001).

Existem no País algumas propostas municipais e estaduais comprometidas com causas populares e democráticas que através de parcerias entre a sociedade civil 
organizada e a academia têm construído propostas de políticas públicas de saneamento que consideram os princípios de universalização, equidade, integralidade e participação social (MORAES 2001).

O autor indica que nos últimos anos o governo do Estado da Bahia tem investido em ações fragmentadas no setor de saneamento, apenas em algumas áreas turísticas.

A partir desse referencial teórico, centrado em conceitos de qualidade de vida, cidadania e políticas públicas foram enfocados os objetivos do estudo para posterior discussão dos dados empíricos utilizados como base de análise da pesquisa. 


\section{OBJETIVOS}

\subsection{Objetivo Geral}

Analisar as políticas públicas no Município de Feira de Santana relacionadas com a qualidade de vida da população expressa no Índice de Desenvolvimento Humano (IDH).

\subsection{Objetivos Específicos}

Analisar a previsão e execução orçamentária do Município no período de 1993 a 2002 com destaque para os investimentos sociais nas áreas de educação, saúde e meio ambiente, contidas na Lei Orgânica do Município.

Descrever os índices de desenvolvimento humano e condições de vida do Município de Feira de Santana.

Identificar as ações da administração pública municipal nas áreas de educação, saúde e meio ambiente para análise dos pontos convergentes e divergentes entre as ações realizadas, as exigências contidas na Lei Orgânica do Município, na aplicação orçamentária do município e o Índice de Desenvolvimento Humano Municipal. 


\section{Cenário da Pesquisa}

A pesquisa foi realizada no Município de Feira de Santana situada na região do semi-árido do Estado da Bahia, distante $108 \mathrm{Km}$ da capital, Salvador (Figura No 2).

Figura 2 Vista postal do centro da Cidade de Feira de Santana, 2000

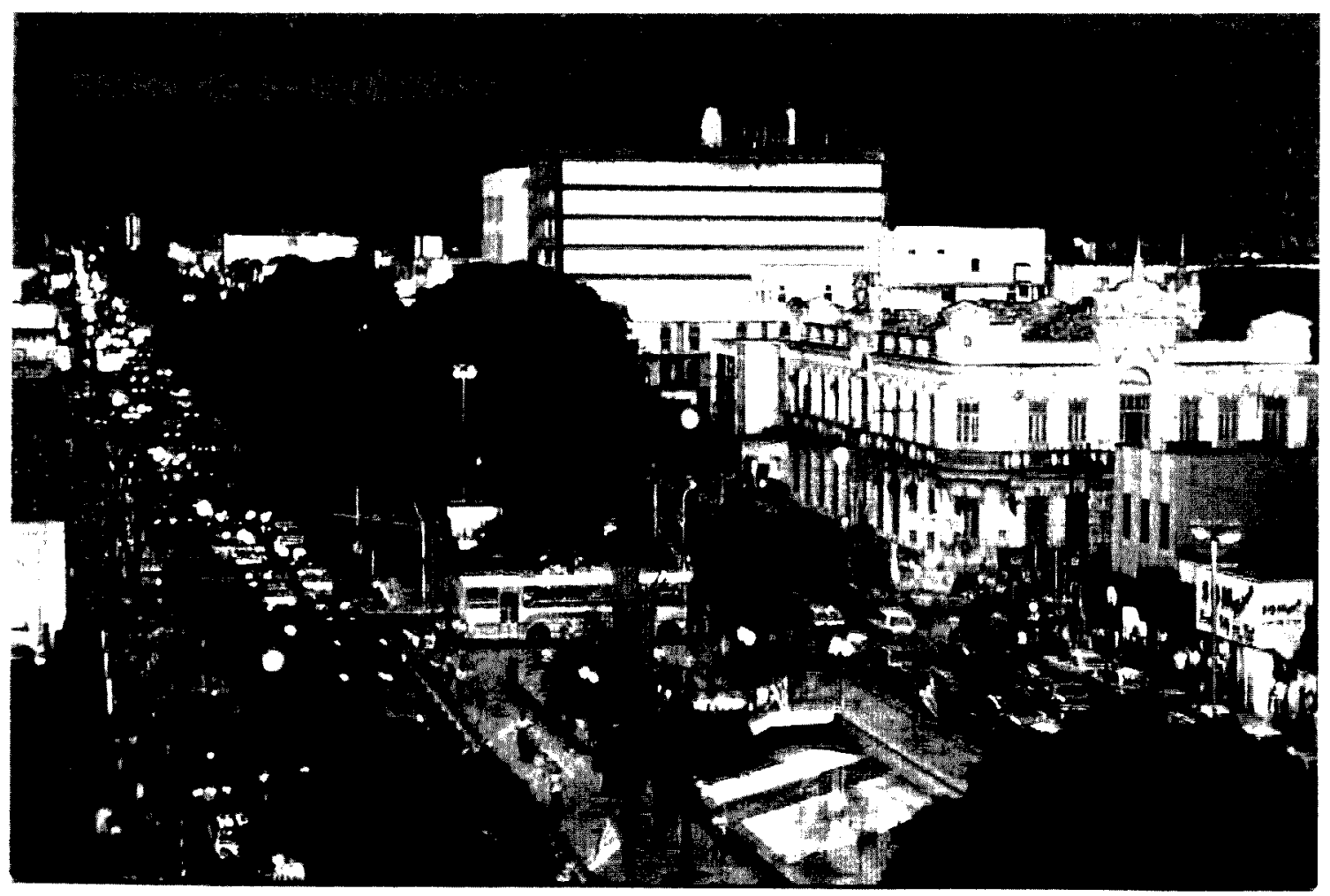

\subsection{Histórico do Município}

O município de Feira de Santana teve sua origem em meados do século XVII com o Morgado de São José das Itapororocas, hoje Distrito de Maria Quitéria, a partir de formações de Fazendas e Currais (GAMA 2001; GALVÃO, 1982)).

Os historiadores enfatizam que a fixação do homem neste sítio deve-se à rede hidrográfica composta pelos rios, Jacuipe, Pojuca e Subaé, além dos alagadiços que se estendem na vastidão do tabuleiro que servia de pórtico para o sertão. 


\section{Figura 3 Rua Sales Barbosa - Antiga Praça do Comércio}

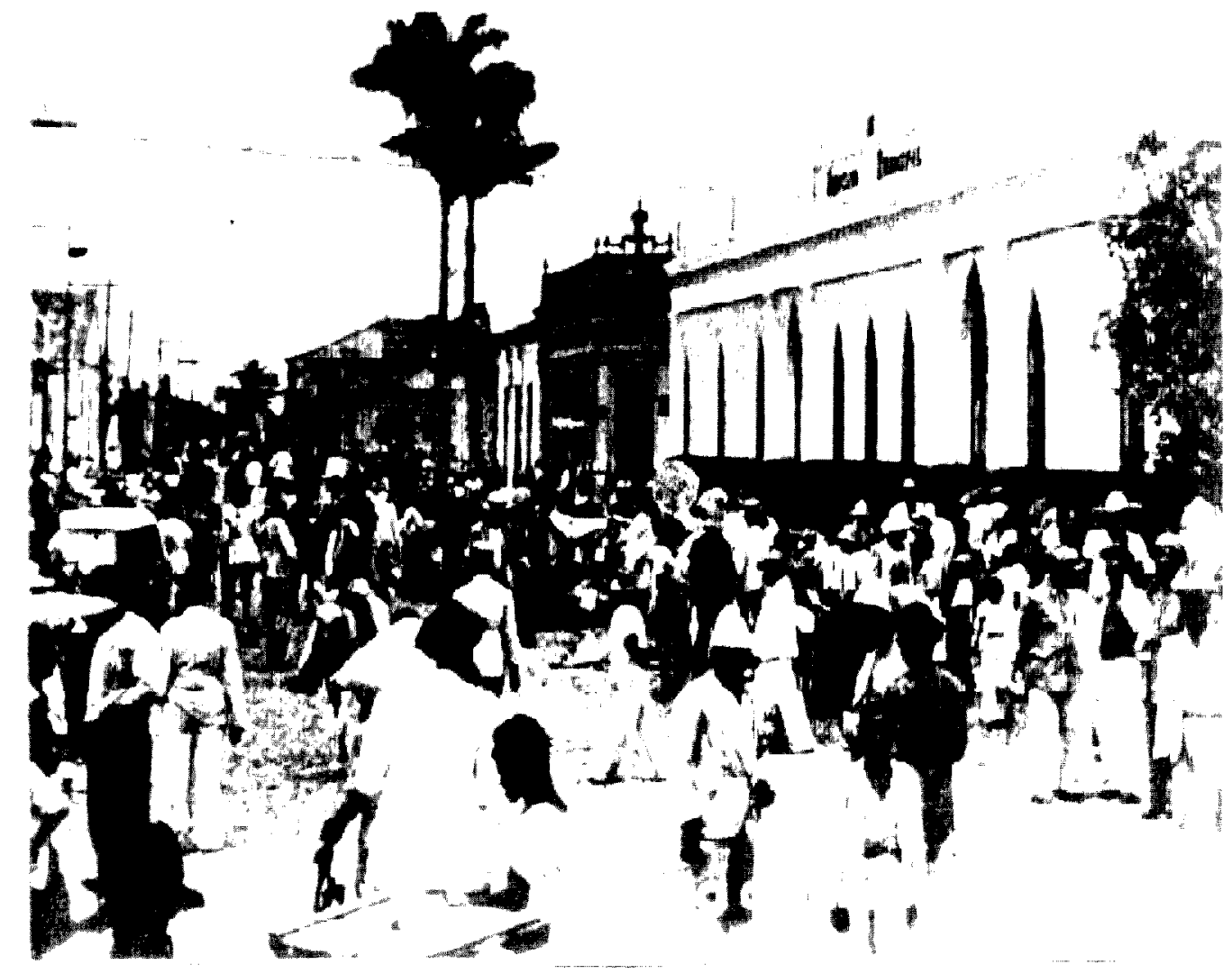

No século XVIII, por volta do ano de 1732 surgiu um povoado originado da Fazenda Santana dos Olhos d'Água que pertencia à paróquia de São José das Itapororocas, local que dava passagem ao gado vindo do sertão, para ser vendido nas cidades de Cachoeira, Santo Amaro e Salvador. Formou-se, no local, uma feira de gado, onde também era efetuada a comercialização de outras mercadorias, dando origem ao povoado de Santana da Feira.

O povoado cresceu, tornou-se vila e em 1833, emancipou-se de Cachoeira, passando a ser conhecida como Cidade Comercial de Feira de Santana. Nessa época, Feira de Santana passou a se interligar com Cachoeira / São Félix, próspera região do recôncavo baiano, através de estrada de ferro, especializando-se no comércio de fumo e carne bovina, passando a se tornar um entreposto de matérias-primas para a emergente produção do Recôncavo.

A comercialização de gado manteve-se como uma atividade importante, atingindo seu auge em 1950 e começando a diminuir na década de 1960, época em que a rodovia BR 324 (Feira - Salvador) foi asfaltada. 


\section{Figura 4 Campo do Gado - Antigo}

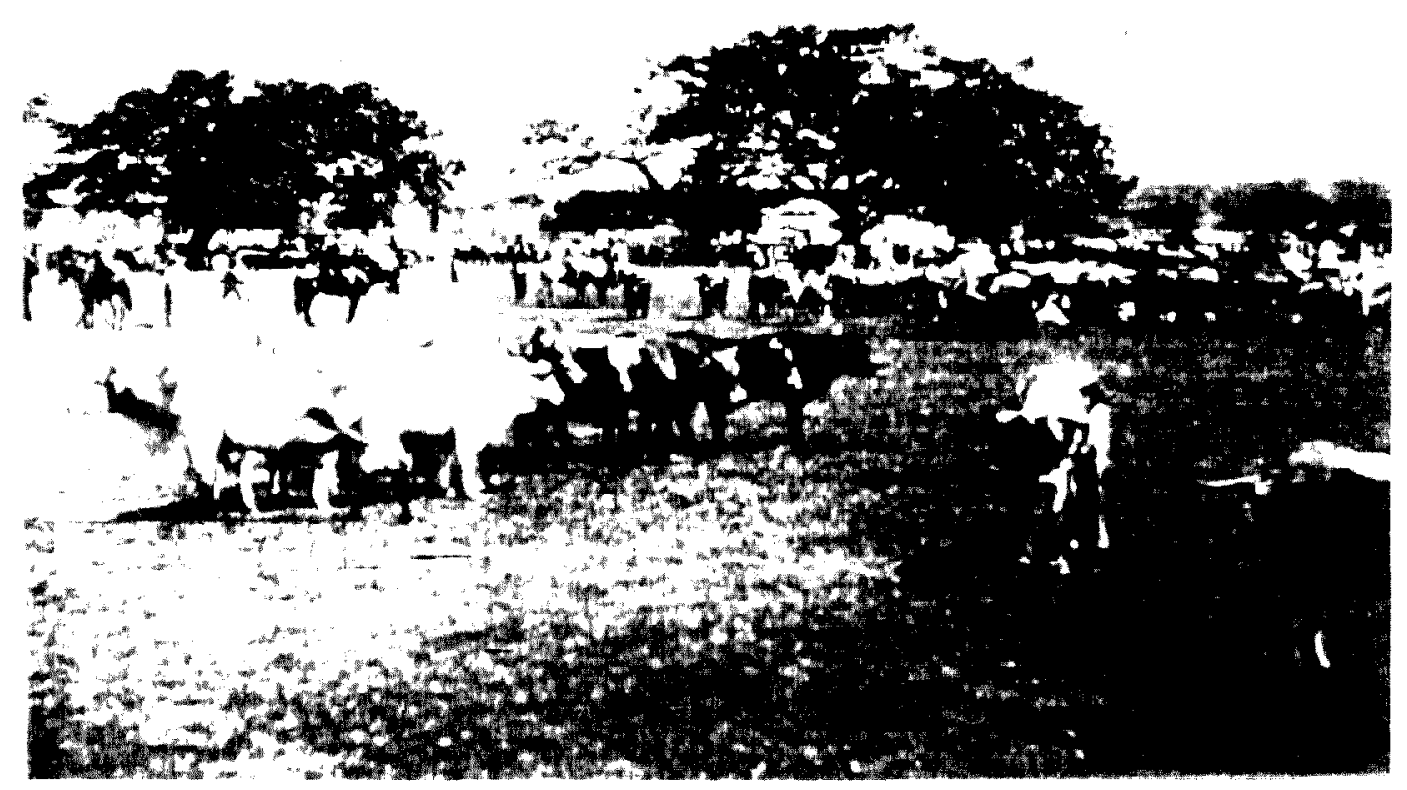

De 1950 a 1980, houve uma grande alteração na estrutura da cidade, com o crescimento dos estabelecimentos comerciais e a elevação da oferta de empregos. Em 1970, com a política de desenvolvimento industrial, ocorreu a implantação do Centro Industrial Subaé.

$\mathrm{Na}$ década de 1990, os tradicionais pilares da economia do município foram abalados pelo quadro conjuntural de seca e perda de parte dos rebanhos. Com o fim dos incentivos fiscais, concedidos na época de implantação das indústrias, muitas empresas fecharam as portas e voltaram ao seu lugar de origem.

\subsection{Aspectos Físicos e Espaciais}

A partir de 1920 até 1950, Feira de Santana tornou-se o centro de um novo sistema de rodovias planejado pelo governo federal e estadual, colocando, o Nordeste do Estado da Bahia numa posição estratégica entre Norte/Nordeste e Sul/Sudeste do país (Figura 5). 
Situada no maior entroncamento rodoviário do Norte/Nordeste do país (BR 101, 116 e 324, BA 052 e 502), a 234 metros de altitude e ocupando uma área de 1.344 $\mathrm{km} 2$, tem uma precipitação média anual entre 900 e $1.400 \mathrm{~mm}$, com uma temperatura média anual de $24,1^{\circ} \mathrm{C}$, sendo os períodos chuvosos de abril a junho e de setembro a dezembro. O clima é subtropical quente e semi-úmido, o seu solo caracterizado como predominantemente arenoso, a vegetação típica da região é a caatinga (SPÍNOLA e SPÍNOLA 1988).

Figura 5 Articulação das Rodovias Estaduais e Federais em Feira de Santana

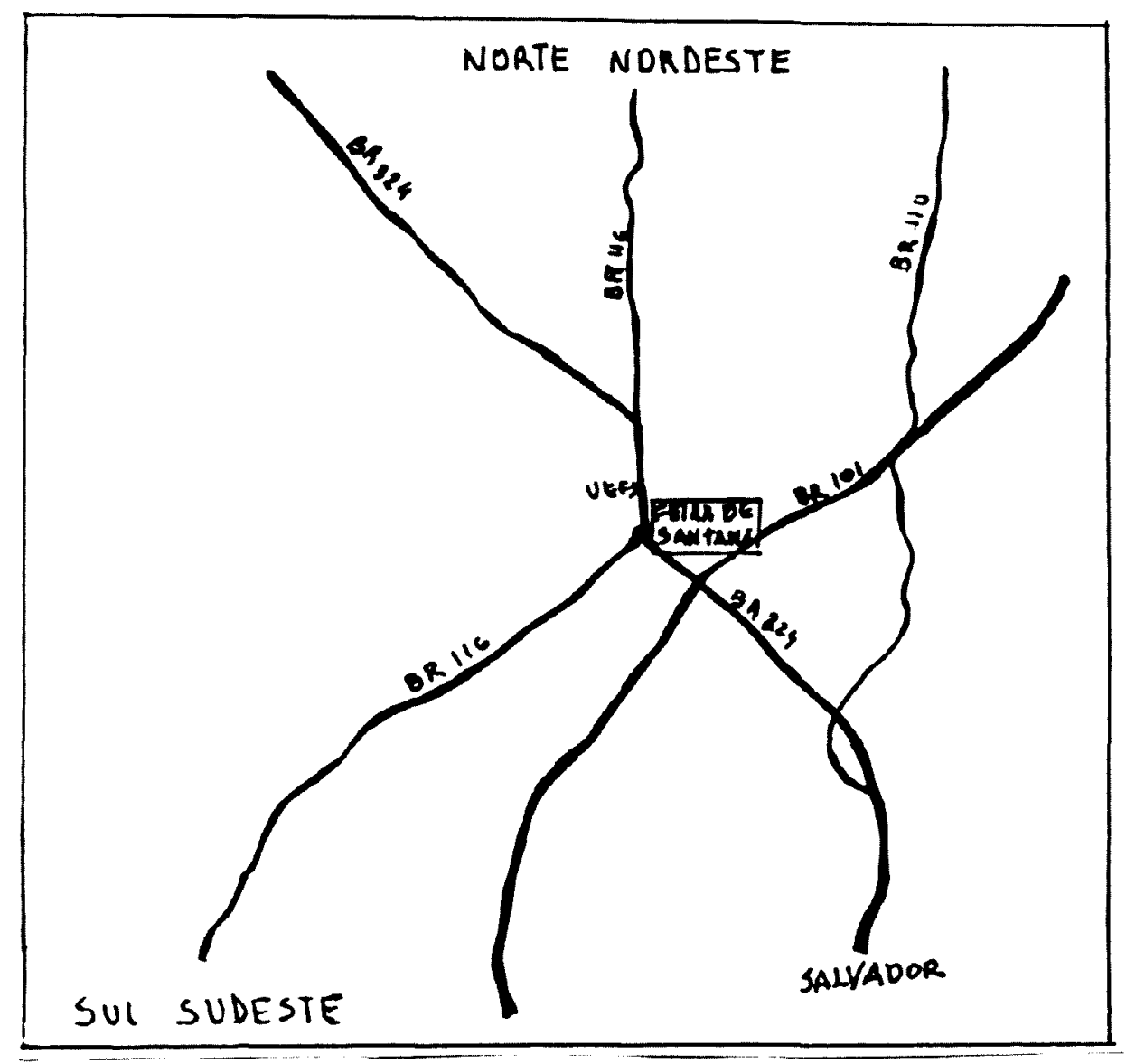




\subsection{Aspectos Demográficos e Renda}

Feira de Santana, município situado a $108 \mathrm{Km}$. da capital do Estado da Bahia, segundo estimativa do IBGE (2000), possui uma população de 480.692 habitantes, apresentando uma densidade demográfica de 358,2 hab $/ \mathrm{km} 2$, concentrando o segundo maior contingente populacional urbano do Estado, superada apenas por Salvador, capital do Estado. Apresenta grande fluxo migratório de regiões mais pobres para o município o que tem concorrido para a degradação ambiental e aumento do contingente populacional de baixa renda.

A situação geográfica do município de Feira de Santana, como eixo rodoviário facilita o processo migratório que se mantém crescente. Além da migração interna do município que ocorre da zona rural para a zona urbana, há, em maior número, a migração de outros municípios para Feira de Santana. A maioria dos migrantes caracteriza-se por não ter renda nem instrução, sem ter condição de competir no mercado de trabalho e por ocuparem geralmente habitações subumanas, na periferia da cidade (ARAÚJO 2001).

No período de 1991 a 1996, a população apresentou uma taxa de crescimento geométrico de $2,1 \%$. Nos últimos anos, essa taxa tem sido de $2.2 \%$ enquanto as taxas da Bahia e Brasil correspondem a $1.14 \%$ e 1.40 respectivamente (IBGE 2000).

Como resultado dessa dinâmica de ocupação espontânea da periferia por sucessivas levas de migrantes, Feira de Santana já apresentava, no início da década de 1990 um percentual de $35,8 \%$ de famílias indigentes em relação a sua população total, classificando-se como a $13^{\text {a }}$ cidade baiana em relação ao número de famílias indigentes (SPÍNOLA e SPÍNOLA 1998).

Apesar dos percentuais acima referidos, os quais refletem que mais de um terço da das famílias é de indigentes, os dados de desenvolvimento humano do PNUD/IPEA/FJP apontam que Feira de Santana em 1991 possuía o segundo maior Índice de renda na Bahia - 0,677, ficando apenas atrás de Salvador com 0,925 que se encontra próximo ao Índice do Brasil que é 0,942 para o mesmo ano. 


\subsection{Educação}

A questão da educação transcende à escola. A política do Governo Federal parte do reconhecimento da multiplicidade de problemas, de forma a criar condições para ampliar o atendimento à população e para melhoria geral da qualidade do ensino (GUIMARÃES 1996).

Possivelmente, a explicitação do maior esforço do governo federal de incentivo à política educacional nos últimos anos, tenha ocorrido através da instituição da Emenda Constitucional $\mathrm{n}^{\mathrm{o}}$ 14, de 12 de setembro de 1996, regulamentada pela Lei n.9.424, que criou o Fundo de Manutenção e Desenvolvimento do Ensino Fundamental e de Valorização do Magistério (FUNDEF), que prevê o seu controle e gestão, cujo impacto deverá ser avaliado após mais alguns anos de sua implementação.

A execução da política educacional em Feira de Santana fica a cargo dos governos estadual e municipal, cabendo ao Município, prioritariamente, a condução do primeiro grau, incluindo a zona rural com escolas pequenas e desaparelhadas, e ao Estado, a condução predominante do segundo grau, embora mantenha escolas de primeiro na zona urbana do Município (Secretaria Municipal de Educação 2000).

Os índices de alfabetização, em Feira de Santana, apresentaram melhoria. Entre os anos de 1970 e 1994, a taxa de analfabetismo passou de $46,3 \%$ para $27 \%$, índices ainda considerados altos (SPÍNOLA e SPÍNOLA 1998).

Os percentuais de analfabetismo de acordo com dados do PNUD/IPEA/FJP apresentam valores mais baixos e são discutidos no capítulo dos resultados no item sobre o sistema de educação de Feira de Santana.

No tocante ao ensino básico, em 2002, funcionavam 405 estabelecimentos de ensino de $1^{\circ}$ grau no Município, sendo 93 unidades da rede estadual e 218 da rede municipal, além de 72 particulares (SPÍNOLA e SPÍNOLA 1998 e Secretaria Municipal de Educação de Feira de Santana 2002).

O total de matrículas, no $1^{\circ}$ grau, atingiu cerca de 72.000 estudantes e, no $2^{\circ}$ grau 12.483. Vale salientar que esse número de estudantes engloba alunos provenientes de municípios vizinhos. 
$\mathrm{Na}$ educação superior, com quase 26 anos de funcionamento, a Universidade Estadual de Feira de Santana mantém 25 cursos de graduação com 5.908 alunos matriculados, 65 cursos de pós-graduação, sendo 54 a nível de especialização e 11 de mestrado e doutorado.

\subsection{Saúde}

A implementação do Sistema Único de Saúde no Município de Feira de Santana, como política de saúde, sofre os reflexos configurados pelo atraso observado em quase todo o Estado da Bahia, por problemas políticos do próprio Estado e do Município, em que as políticas públicas ainda não representaram sequer uma prioridade para o município, haja vista os baixas dotações orçamentárias explicitados no quadro 7.

A rede municipal expandiu-se com unidades de atendimento primário e um hospital especializado e os recursos financeiros do município alocados no setor saúde ficaram no patamar de $11,7 \%$ da arrecadação em 1997, encontrando-se em torno de $12.9 \%$ no ano de 1999 (Lei do Orçamento Anual - LOA) / 1997, 1999).

A rede estadual incorporou algumas unidades federais e os recursos provenientes do Ministério da Saúde para internações e atendimento ambulatorial são transferidos, segundo critérios normativos centrais, para a rede privada, através de convênio de cooperação técnica, e, para os hospitais mantidos pelo Estado, tendo como interlocutor local a Secretaria de Saúde do Estado, representada pela Segunda Diretoria Regional de Saúde - $2^{\text {a }}$ DIRES (ASSIS 1998).

Só em 1993, o município de Feira de Santana passou a receber recursos do governo federal, através do convênio SUS com o Hospital da Mulher, ano em que começa, efetivamente, a implementação do SUS a nível nacional (ASSIS 1988).

Do total de 160 estabelecimentos de saúde no município, $76 \%$ respondiam pelo setor privado, enquanto apenas $24 \%$ pelo público, havendo 4 anos depois uma acentuação dessa distorção em que se verifica aumento ainda maior das instituições privadas em relação às públicas, (ASSIS 1998).

Quando ASSIS (1998) refere que a relação público e privado, na produção dos serviços de saúde em Feira de Santana, não se distancia do contexto nacional em que 
"os serviços estatais operam dentro de uma lógica privatista com interesses clientelistas e corporativos, dada a frágil regulação do Estado", observa-se que a realidade do referido município é compatível apenas com realidades bem distantes daquelas preconizadas pelo Sistema Único de Saúde.

De acordo com essa lógica, constata-se que os recursos financeiros repassados pelo governo federal ao município sejam direcionados ao setor privado, que conta com um total de 122 estabelecimentos (116 lucrativas e 06 filantrópicos), incluindo um total de 160 instituições de saúde, das quais apenas 38 são mantidas pelo poder público (estadual e municipal), configurado-se como serviço básico de saúde. Essa realidade se agrava em 2002 ao se constatar que a relação dos serviços público e privados passa a ser $84 \%$ e $16 \%$ respectivamente, e que dos $84 \%$ privados apenas $9 \%$ são de caráter não lucrativo (ASSIS 1998; MARTINS 2002).

Com relação à rede básica de serviços, o município mantém 37 unidades básicas de saúde com atendimento externo, sendo 23 centros de saúde na área urbana e 14 na zona rural (ASSIS, 1998; COSTA 2001; CERQEUIRA 2001).

Com a implementação da Norma Operacional Básica -NOB SUS 01 - 96 e com o processo de acreditamento do Município de Feira de Santana na condição de Gestão Plena da Atenção Básica, ocorrido em julho de 1997, o município passou a receber o Piso de Atenção Básica (PAB) em fevereiro de 1998. Atualmente, o município recebe, como parte variável do $\mathrm{PAB}$, os repasses referentes ao Programa de Agentes Comunitários de Saúde (PACS); Programa de Vigilância Epidemiológica, Programa de Vigilância Sanitária, Programa de Carências Nutricionais e Programa da Farmácia Básica (Secretaria Municipal de Saúde 2000).

A implementação da Norma Operacional Básica de 1996 (NOB-96), pelo Ministério da Saúde em 1998 pode ter influenciado o aumento da dotação orçamentária do Município de Feira de Santana na área da saúde, através do repasse, fundo a fundo, do Piso de Atenção Básica (PAB) como se percebe na Figura 7.

\subsubsection{Principais Indicadores Epidemiológicos}

O elevado fluxo migratório, as péssimas condições de saneamento básico, as baixas condições de renda e educação do município propiciam a propagação de 
doenças infecto-contagiosas, especialmente de veiculação hídrica e carências com ocorrências epidêmicas. De acordo com CERQUEIRA (2001), o perfil epidemiológico de feira de Santana não difere muito do da maioria dos municípios do Nordeste. Dos casos de notificação compulsória de doenças infecciosas e parasitárias as de maior incidência são as hepatites virais, dengue e as doenças exantemáticas como sarampo e rubéola.

A autora afirma, também, que as doenças do aparelho circulatório figuram como a principal causa de morte que acomete, predominantemente, a faixa de 50 anos e mais; em segundo lugar, registram-se as mortes causadas pelas chamadas causas externas, que atingem, preferencialmente, a faixa etária de 15 a 49 anos do sexo masculino e, em terceiro lugar, os óbitos causados por neoplasias.

\subsubsection{Coeficiente de natalidade e fecundidade}

A taxa de natalidade, além de ser empregada para acompanhar o que ocorre à população, com o passar do tempo, é também usada no cálculo do crescimento natural da população e a taxa de fecundidade geral fornece uma noção mais apropriada da geração de filhos, na população. (PEREIRA M 1995).

$\mathrm{Na}$ Bahia, ocorreu, nos últimos anos, um grande aumento do coeficiente de natalidade e, em Feira de Santana, esse aumento é da ordem de sete vezes mais, passando de 3,67 por mil nascidos vivos em 1995 para 21,93 por mil nascidos vivos em 1997. Para o coeficiente de fecundidade global, pode ser utilizado o mesmo raciocínio, sendo que o aumento, em Feira de Santana, foi em torno de 6 vezes, configurando-se um aumento de 13,29\% em 1995 para 72,02\% em 1997, de acordo com dados do MS - IDB (1998).

Esses índices podem pressionar o aumento da mortalidade infantil, considerandose que o maior crescimento da população se dá no grupo populacional de baixa renda. 


\subsubsection{Mortalidade infantil}

De acordo com ROUQUAYROL (1994), a mortalidade neonatal (entre 0 e 28 dias de nascido) é, geralmente atribuída a problemas inerentes à gravidez, parto, anomalias congênitas e cuidados com o recém nascido. Isso poderia ser amenizado, se houvesse um melhor acompanhamento das mães durante o pré-natal. Enquanto isso, a mortalidade infantil tardia é devido a fatores adversos do meio ambiente, cujas principais causas se relacionam às doenças infecciosas e parasitárias e a doenças respiratórias.

A mortalidade infantil é um dos principais indicadores de saúde da população e, apesar dos problemas relacionados à sub-notificação, deve servir como orientador da política de saúde do município.

Como medidas preventivas, deve-se implementar ações básicas de saúde infantil, como o incentivo ao aleitamento materno, terapia de reidratação oral, imunização e monitorização do desenvolvimento e crescimento (ROUQUAYROL 1994).

No município de Feira de Santana, observa-se uma queda gradativa no índice de mortalidade em menores de 5 anos - em 1998, foi de 25,17; em 1999 foi 24,53 e em 200021,70 por mil nascidos vivos. Esses índices foram calculados considerando-se as diversas fontes possíveis de levantamento de dados, como cartório, Secretaria de Desenvolvimento Social, plantão central da delegacia de polícia e hospitais. Ainda assim considera-se a possibilidade de sub-notificação que, para alguns autores, pode chegar a $80 \%$ (ALMEIDA KB 2002).

\subsubsection{Mortalidade Geral}

Em Feira de Santana, de acordo com dados da Secretaria Estadual de Saúde da Bahia (SESAB), para 1999, a maior proporção de óbitos, por grupo de causas e faixa etária, compreende a seguinte sequiência: doenças do aparelho circulatório, 43,9\% em pessoas de 50 anos e mais; causas externas, $41,2 \%$ entre 15 e 49 anos, enquanto que, na faixa de menores de um ano, o predomínio é de mortalidade por afecções perinatais, com o índice de $39,5 \%$. Os 6 grupos de causas de óbitos predominantes em Feira de Santana são: doenças cardio-vasculares - 34,4\%; causas externas - 
15,7\%; neoplasias - 10,1\%; doenças endócrinas nutricionais e metabólicas - 9,4\%; doenças do aparelho respiratório $-8,1 \%$ e sinais e sintomas mal definidos $-6,3 \%$.

\subsection{5 Índice de Swaroop \& Uemura}

O Índice de Swaroop \& Uemura, de acordo com ROUQUAYROL (1994), é um excelente indicador do nível de vida do qual a saúde faz parte. Este índice significa a percentagem de pessoas que morreram com 50 anos e mais em relação ao total de óbitos ocorridos em determinada população. Nos países desenvolvidos, esse índice apresenta valores compreendidos entre 80 e $90 \%$. No Brasil, de acordo com dados do IBGE (2000), de 1991 a 2000 - houve um ganho de 2,6 anos, e a esperança de vida ao nascer passou de 66 anos em 1991 para 68,6 em 2000, sendo que para as mulheres, foi de 72,6 anos e os homens 64,8 anos.

De acordo com os achados de BARBONI (2002), o Município de Salvador apresenta uma esperança de vida ao nascer de 64,10 anos para homens e 70,33 para mulheres.

No município de Feira de Santana, o percentual registrado para 1997 foi de $66,08 \%$, índice equiparado ao de cidades de porte semelhante, da região sudeste do Brasil (CIS 2000).

\subsection{Saneamento Básico}

Cerca de $95 \%$ da população da cidade de Feira de Santana é atendida pelo sistema integrado de abastecimento de água, operado pela Empresa Baiana de Saneamento (EMBASA), que atende aos distritos e municípios vizinhos com capacidade de produção de $1.500 \mathrm{l} / \mathrm{s}$ e operação ao nível de $1.090 \mathrm{l} / \mathrm{s}$.

Atualmente, Feira de Santana possui uma rede de abastecimento de água composta por 87.037 ligações, com água proveniente da barragem de Pedra do Cavalo e vem operando com uma vazão de $94.694,40$ 1/d.

O sistema de esgotamento sanitário é precário, apresentando uma cobertura de menos de 1/3 dos imóveis da cidade, enquanto os demais dispõem de sistema de fossas, comprometendo o lençol freático, ou se utilizando de ligações clandestinas de 
esgoto, que despejam os dejetos in natura, diretamente nos córregos e rios que percorrem a cidade. O rio Jacuípe é o que recebe a maior parte dos dejetos domésticos, desaguando sua poluição no rio Paraguaçu, na altura do reservatório Pedra do Cavalo (SPÍNOLA e SPÍNOLA 1998).

A coleta e a destinação dos resíduos sólidos também são executadas de forma precária. Não existe coleta seletiva e o aterro sanitário, além de estar com sua capacidade física esgotada, é carente de equipamentos, tais como drenos para gases e chorume. Acrescido a isso, constata-se a inexistência de área específica para disposição do lixo hospitalar.

Contrastando com as condições adversas do saneamento ambiental, Feira de Santana conta com um Código de Meio Ambiente aprovado pela Lei Complementar $\mathrm{N}^{\mathrm{o}} 1.612 / 92$ e possui um Conselho Municipal de Defesa do Meio Ambiente CONDEMA, além da Agenda 21, instituída no ano 2000, cuja atuação de seus representantes, ainda é insuficiente. 


\section{METODOLOGIA}

\subsection{Tipo de Pesquisa}

Trata-se de um estudo descritivo, que aborda aspectos quantitativos e qualitativos das políticas públicas no Município de Feira de Santana, relacionadas ao perfil de qualidade de vida da população expresso no Índice de Desenvolvimento Humano (IDH).

Foram utilizados dados quantitativos que expressam o Índice de Desenvolvimento Humano do Município de Feira de Santana; e os contidos nos orçamentos anuais do município, considerando-se que a análise documental, no estudo descritivo, fornece ao investigador a possibilidade de reunir uma grande quantidade de informações tros textos (TRIVINOS 1992).

Os a

im obtidos nas entrevistas semi-estruturadas com alguns

secretários municipui.. implementadas e ou implantadas; referentes às competências do município nas áreas de educação, saúde e meio ambiente contidas na Lei Orgânica municipal.

Embora esses aspectos englobem dados qualitativos e quantitativos, a opção pela abordagem qualitativa na análise foi pensada como uma opção ideológica necessária e também, mas como forma de aprofundar o caráter social e as dificuldades de construção do conhecimento que o apreendem de forma parcial e inacabada (MINAYO 2000).

Tendo em vista a natureza dos dados coletados, permite-se a utilização da técnica de triangulação na coleta de dados que, de acordo com TRIVIÑOS (1992), possibilita uma maior amplitude na descrição, explicação e compreensão do foco do estudo.

$\mathrm{O}$ processo de triangulação foi realizado tomando-se, como primeiro vértice do triângulo, a legislação municipal: Lei Orgânica do Município e Leis Orçamentárias Anuais do período de 1993 a 2002; como segundo vértice os dados do Índice de Desenvolvimento Humano do Município de Feira de Santana; e como terceiro os dados das entrevistas semi-estruturadas. 


\subsection{Estratégias de Investigação}

Os dados da pesquisa foram organizados para fins de análise em qualitativos e quantitativos. Os quantitativos referente ao desenvolvimento humano do município de Feira de Santana e às Leis de Orçamento Anual do município estudado, no período de 1993 a 2003; e qualitativos, a partir dos dados contidos na Lei Orgânica do município relacionados com as áreas de educação, saúde e meio ambiente, como diretrizes orientadoras das ações municipais, e as atividades desenvolvidas no âmbito das secretarias municipais nas mesmas áreas citadas, obtidos em entrevistas semiestruturadas.

\subsection{Análise quantitativa}

Com a intenção de balizar este estudo pelo Índice de Desenvolvimento Humano e Condições de Vida, foi realizado um levantamento de dados a partir da publicação do Programa das Nações Unidas para o Desenvolvimento (PNUD); Instituto de Pesquisa Econômica Aplicada (IPEA); Fundação João Pinheiro (EJP) e Instituto Brasileiro de Geografia e Estatística (IBGE) e dos dados disponíveis sobre IDH e ICV do município de Feira de Santana.

Foram construídas dois quadros do Índice de Desenvolvimento Humano (IDH) de Feira de Santana com os itens de longevidade (saúde), educação e renda nos anos de 1970, 1980, 1991 e outra com o Índice de Condições de Vida (ICV) com os itens de longevidade, educação, infantil, renda e habitaçãn períodos de 1970, 1980 e 1991.

O ICV foi desdobrado em 5 quadros:

longevidade, longevidade ao nascer e ' , talidade infantil;

educação, menos de 4 anos de est $!$ menos de 8 anos de estudo, menos de 11 anos de estudo, taxa de analfabetisn . $\quad .15$ anos e mais, anos médio de estudo de 25 anos e mais; 
infantil, criança de 7 a 14 anos fora da escola, defasagem escolar de 10 a 14 anos, mais de um ano de atraso de 10 a 14 anos, percentual de crianças que trabalham de 10 a 14 anos;

renda, renda per capita média, grau de desigualdade, renda insuficiente, insuficiência média, grau de desigualdade para a população com média insuficiente;

habitação, densidade superior a duas pessoas por dormitório, material de construção durável, abastecimento adequado de água e disponibilidade de esgoto referente aos anos de 1970, 1980, 1991.

Para viabilizar a coleta de dados referentes aos orçamentos municipais e como forma de aproximação com o objeto de pesquisa, foram realizadas visitas à Câmara de Vereadores para conhecer os textos das leis orçamentárias aprovadas ao longo dos dez últimos anos e os caminhos percorridos pelos documentos orçamentários, até serem transformados em Lei que, depois de executadas, eram encaminhadas ao Tribunal de Contas do Município.

Durante as várias consultas aos arquivos da Câmara de Vereadores, os funcionários disponibilizaram cópias dos documentos orçamentários e o acesso aos arquivos para a consulta. Vale salientar que os orçamentos dos anos mais recentes não estavam disponíveis na Câmara de Vereadores e que só foi possível encontrá-los na Prefeitura Municipal, contando com o apoio de um funcionário que forneceu informações importantes sobre o processo do trabalho.

Os dados referentes às leis orçamentárias anuais compreendidas entre 1993 e 2002 foram organizadas em dois quadros (12 e 13) descrevendo a evolução orçamentária do município de Feira de Santana, com o ano, o nimero de lei, o montante do moeda corrente e cada rubrica jasto e a dotação orçame

\section{s.4 Análise qualitativa}

Para orientar a coleta e análise de dadoc yualitativos, foram focalizadas, na Lei Orgânica do Município (Lei $\mathrm{N}^{\mathrm{o}} 37$ de 190 ), no Capítulo da ordem econômica e social nos artigos 118, 128, 132, i34 e 157, as competências do município 
relacionadas às áreas de educação, saúde e meio ambiente, que se constituem como eixos temáticos da investigação. Esses dados foram ordenados no Quadro 4.

As entrevistas semi-estruturadas, foram realizadas em duas etapas: exploratória e coleta propriamente dita.

\subsection{Etapa exploratória}

Nesse período, foi possível realizar, com secretários, cinco entrevistas de maior importância para aproximação do objeto pesquisado, durante a elaboração do projeto de pesquisa, como forma de aproveitar a gestão municipal cujo mandato estava finalizando. Foram entrevistas semi-estruturadas, cujo eixo orientador foi o planejamento e a execução das ações desenvolvidas na respectiva secretaria, o que possibilitou coletar um grande número de informações, configurando-se como um primeiro bloco de dados primários.

Desse primeiro bloco de entrevistas com os secretários, as duas primeiras não foram gravadas, a primeira delas por opção da própria pesquisadora, no sentido de oferecer um ambiente mais informal ao entrevistado. O secretário fez comentários sobre sua pasta e sobre a administração municipal como um todo.

A segunda entrevista do primeiro bloco não foi gravada porque o secretário preferiu disponibilizar os planos que já se encontravam em execução e fez breves comentários sobre sua pasta. As demais entrevistas, em número de três, relacionadas às pastas de educação, saúde e meio ambiente, foram gravadas e os entrevistados utilizaram em torno de 40 minutos a uma hora. Essas entrevistas foram prontamente marcadas e realizadas em junho do ano $2000 \mathrm{e}$, posterimente, avaliadas, quanto à estrutura e a importância de inclusão na pesquisa.

\subsection{A coleta de dados nas entrevistas}

As entrevistas do segundo bloco de entrevistas foram realizadas com dez secretários municipais, após alguns meses de instalado o novo governo, no período de junho de 2001 a janeiro de 2002, com auxílio de gravador e transcritas pela própria pesquisadora, tendo havido algumas dificuldades metodológicas. 
O que marcou esse bloco de entrevistas foi a consolidação do projeto de pesquisa, que já se encontrava totalmente estruturado, com o roteiro de entrevista definido, e, por parte dos secretários, a grande dificuldade foi conseguir marcar um primeiro encontro para falar sobre o trabalho de pesquisa. Os primeiros contatos foram feitos com o(a) chefe de gabinete, que exigiu um roteiro prévio e um prazo mínimo de quinze dias para marcar a entrevista com várias remarcações posteriores.

Diante da exigência de um dos secretários de conhecer o roteiro antes da entrevista, decidiu-se fazê-lo para todos os secretários.

Como no primeiro bloco de entrevistas, um dos secretários se destaca, quando faz uma abordagem específica de sua pasta e do governo como um todo, o que pareceu assumir uma postura de liderança no governo municipal, a pesquisadora pensou em entrevistá-lo uma segunda vez, no sentido de compreender melhor como ocorre o processo da intersetorialidade no âmbito da administração municipal.

Durante o período das entrevistas, houve uma audiência com o prefeito, com a presença da orientadora da pesquisa, na qual foi feita uma explanação dos objetivos da pesquisa, expondo-se como seria desenvolvido o trabalho e quais as perspectivas sobre a importância do trabalho. O prefeito mostrou-se gentil e desejou êxito para o trabalho.

\subsection{Sujeitos da pesquisa:}

Secretário Municipal de Administração

Secretário da Fazenda

Secretário Municipal de Comunicação Social

Secretário Municipal de Planejamento

Secretário Municipal de Educação;

Secretário Municipal de Cultura, Esporte e Lazer;

Secretário Municipal de Saúde;

Secretaria Municipal de Desenvolvimento Social;

Secretário Municipal de Desenvolvimento Urbano e Meio Ambiente;

Secretário Municipal de Serviços Públicos. 


\subsection{Análise dos dados empíricos}

Os dados empíricos foram organizados em três etapas operacionais e submetidos à análise descritiva, estabelecendo-se a triangulação dos dados e os dados das entrevista foram utilizadas no texto conforme informações dos sujeitos - sic.

\section{$1^{\text {a }}$ ETAPA}

$\mathrm{Na}$ primeira etapa, foram ordenados e classificados três conjuntos de dados secundários, sendo o primeiro referente à Lei Orgânica do Município; o segundo, sobre o Índice de Desenvolvimento Humano Municipal; o terceiro, sobre a Lei Orçamentária Anual (LOA), referente ao período de 1993 a 2002.

Tomou-se como ponto de partida a Lei Orgânica do Município de Feira de Santana, publicada em abril de 1990 e atualizada em junho de 2000, na qual estão discriminadas as competências do município.

$\mathrm{Na}$ ordenação dos dados, fez-se, inicialmente, uma primeira leitura de toda a documentação pertinente, denominada de leitura flutuante. A seguir, procedeu-se à escolha dos documentos, seguindo as regras de exaustividade, homogeneidade, representatividade e pertinência (BARDIN 1995; MINAYO 2000)

Nessa etapa se procedeu ao detalhamento de cada material a ser trabalhado construindo-se o primeiro quadro que tratou, sobre as competências do município em que são destacados alguns artigos da Lei Orgânica do Município, de acordo com tema eixo da pesquisa, que está representado no Quadro 4.

O segundo conjunto de documento é composto por sete quadros onde estão discriminados os índices de desenvolvimento humano e de condições de vida do município de Feira de Santana de acordo com dados do PNUD / IPEA / FJP / IBGE (1998).

Para o Índice de Desenvolvimento Humano do Município (IDHM), foram elaboradas duas tabelas contendo o ordenamento do IDHM de Feira de Santana, do Índice de Condições de Vida (ICV) e mais cinco tabelas com os percentuais contidos no ICV do Município de Feira de Santana com os dados disponíveis do Programa das Nações Unidas para o Desenvolvimento (PNUD); (Instituto de Pesquisas 
Econômicas Aplicadas (IPEA); Fundação João Pinheiro (FJP) e Instituto Brasileiro de Geografia e Estatística (IBGE)

O terceiro conjunto de dados está representado pela evolução orçamentária municipal referente ao período de 1993 a 2002, nos quadros 12 e 13, em que se procedeu ao ordenamento dos dados orçamentários do município, com a discriminação dos gastos em moeda corrente e os percentuais representados no orçamento por cada rubrica.

\section{$2^{\text {a }}$ ETAPA}

Na segunda etapa, foram ordenados e classificados os dados primários, resultantes das entrevistas semi-estruturadas, realizadas com os secretários de governo do município, utilizando-se o método de análise de conteúdo, de acordo com MINAYO (2000).

nresentados os dados primários provenientes das entrevistas semi-estruturadas realizadas com os secretários municipais, orientadas por um roteiro previamente elaborado (anexo 2 ).

Uma boa entrevista, qualquer que seja a técnica utilizada, implica na necessidade de um conhecimento prévio das características da população, para que não haja desvio do objetivo proposto (MINAYO 2000). É importante que o entrevistador, durante a entrevista, tenha consciência de que deverá ocorrer o exercício da intersubjetividade devido ao processo de interação que se dá entre entrevistado e entrevistador.

Foram realizadas entrevistas semi-estruturadas com 10 secretários municipais, responsáveis pela implementação de políticas públicas no Município de Feira de Santana.

A maioria dos secretários de governo do município foi entrevistada na sua própria secretaria, sendo que apenas um secretário escolheu outro local para a entrevista, local em que supervisionava serviços de sua secretaria, apresentando como justificativa, evitar uma nova remarcação.

As entrevistas foram realizadas apenas uma vez pela pesquisadora com cada secretário, e tiveram duração máxima de 60 minutos cada tendo sido utilizado um 
roteiro direcionado a identificar as ações desenvolvidas nas diversas secretarias de governo municipal e a relação existente entre elas e a Lei Orgânica do município e as Leis Orçamentárias.

A função de planejamento torna-se essencial como proposta técnica consistente para execução de políticas, contribuindo para a organização dos serviços públicos em termos qualitativos e quantitativos (PEREIRA JM. 1999).

Após a realização das entrevistas com utilização da gravação devidamente consentida pelo entrevistado, ela foi transcrita e codificada com número de ordem para dificultar a identificação dos entrevistados.

As entrevistas foram classificadas de acordo com os núcleos de sentido, passandose, em seguida, ao processo de categorização, considerando-se trechos das entrevistas la acordo com o método preconizado por MINAYO (2000) e observando os $\mathrm{sc}=\mathrm{nans}$

- fork... . exaustiva - "leitura flutuante" dos textos;

- foram extraídas as falas predominantes ou consideradas importantes devido sua relação com o objeto de estudo, além das divergências, convergências e complementaridades;

- foi realizada leitura transversal e identificados os temas relevantes, constituindo-se os núcleos de sentido do estudo, apreendidos no material empírico.

Quadro 2 - Esquema de Análise das Entrevistas - Núcleos de Sentido

\begin{tabular}{l|l|l|l|l}
\hline Núcleos de sentido & $\begin{array}{l}\text { Entrevista } \\
\mathbf{N}^{\circ} 1\end{array}$ & $\begin{array}{l}\text { Entrevista } \\
\mathrm{N}^{\circ} 2\end{array}$ & $\begin{array}{l}\text { Entrevista } \\
\mathrm{N}^{\circ} \text { I }\end{array}$ & $\begin{array}{l}\text { Síntese } \\
\text { Unidade Temática }\end{array}$ \\
\hline $\begin{array}{l}\text { Planejamento das ações } \\
\begin{array}{l}\text { Gestão (como as ações são } \\
\text { desenvolvidas) }\end{array}\end{array}$ & & & \\
\hline $\begin{array}{l}\text { Financiamento das políticas } \\
\text { públicas }\end{array}$ & & & & \\
\hline $\begin{array}{l}\text { Síntese } \\
\text { Unidade Temática }\end{array}$ & & & & \\
\hline
\end{tabular}




\section{$3^{\text {a }}$ ETAPA}

$\mathrm{Na}$ terceira etapa, organizou-se o esquema orientador para análise dos resultados, delimitando as unidades temáticas que balizaram o estudo, conforme quadro 3

\section{Quadro 3 - Esquema de Análise dos Dados - Unidades Temáticas}

\begin{tabular}{l|l|l}
\hline Unidades temáticas & Síntese dos documentos & Síntese das entrevistas \\
\hline $\begin{array}{l}\text { Lei Orgânica como orientadora } \\
\text { da gestão e planejamento das } \\
\text { ações }\end{array}$ & & \\
\hline As políticas públicas e o IDH & & \\
\hline O Orçamento Anual do & & \\
município e o financiamento das & & \\
políticas públicas & & \\
\hline $\begin{array}{l}\text { Políticas para educação, saúde e } \\
\text { meio ambiente }\end{array}$ & & \\
\hline
\end{tabular}

A análise de documentos administrativos e orçamentários; de indicadores de qualidade de vida expressa no Índice de Desenvolvimento Humano; e dos depoimentos dos Secretários Municipais com relação aos planos de ação e execuções orçamentárias de suas pastas permitiu o entrecruzamento das informações.

Os dados quantitativos e qualitativos mantêm um caráter de complementaridade tornando-se inerentes à natureza do trabalho, em uma análise integrada do material empírico. A começar pelos índices de desenvolvimento humano, eles quantificam a qualidade de vida. Para aperfeiçoamento dessa medida, essa metodologia vem sendo aprimorada para que esse quantitativo expresso em índices indique qualidade o mais aproximado possível da realidade, conforme está descrito na nota técnica do método. Quanto aos dados quantitativos contidos nos orçamentos anuais, eles guardam relação com as exigências qualitativas da Lei Orgânica do município, como diretrizes orientadoras das políticas públicas do município refletidas na alocação de recursos. 
A alocação dos recursos orçamentários, por sua vez, revela as opções políticas de cada administração que pode ficar limitada aos percentuais exigidos em lei sem vinculação com as necessidades da população. De acordo com MINAYO (2000), a dicotomia entre qualitativo e quantitativo pode deixar à margem dados numéricos relevantes e pode contemplar apenas dados subjetivos, distanciando-se da realidade. 


\section{RESULTADOS E DISCUSSÃO}

\subsection{Lei Orgânica como orientadora da gestão e planejamento das ações no âmbito municipal}

A adoção do modelo federal de Estado gravita em torno da autonomia e da participação política, pressupondo a consagração de certas regras constitucionais, tendo em vista sua manutenção. $O$ art. $1^{\circ}$ da Constituição Federal proclama que a República Federativa do Brasil é formada pela união indissolúvel dos Estados, Municípios e do Distrito Federal, e estabelece, no artigo 18, a autonomia e a capacidade de auto-organização e normatização própria, autogoverno e autoadministração.

A Constituição Federal de 1988 consagrou os municípios como entidades federativas indispensáveis ao nosso sistema federativo, merecendo a seguinte colocação de Paulo Benevides, in MORAES (2000):

"Não conhecemos uma única forma de união federativa contemporânea onde o princípio da autonomia municipal tenha alcançado grau de autonomia tão alto e expressivo quanto aquele que consta da definição constitucional do novo modelo implantado no País com a Carta Magna de 1988" (p.261)

Assim sendo, o Município auto-organiza-se através de sua Lei Orgânica Municipal e, posteriormente, por meio da edição de leis municipais; autogoverna-se mediante a eleição direta de seu prefeito, vice-prefeito e vereadores, sem qualquer ingerência dos Governos Estadual e Federal, e auto-administra-se no exercício de suas competências administrativas, tributárias e legislativas, diretamente conferidas pela Constituição Federal (MORAES 2000).

A organização administrativa do Município de Feira de Santana obedece aos preceitos constitucionais contidos no capítulo IV da Constituição Federal, cujo art. 29 reza que "O Município reger-se-á por Lei Orgânica, votada em dois turnos, com o interstício mínimo de 10 dias, e aprovada por dois terços dos membros da Câmara Municipal, que a promulgará, atendidos os princípios estabelecidos nesta constituição e na Constituição do respectivo Estado..." 
Por sua vez, a Constituição do Estado da Bahia, promulgada em 1989, em harmonia com a Constituição Federal, inclui, no Capítulo III, referente aos Municípios, 5 seções.

A seção I estabelece a organização dos municípios no Estado, ressaltando a autonomia política, administrativa e financeira, que deverão ser regidas por Lei Orgânica e demais leis que adotarem.

A seção II estabelece as competências dos Municípios, incluindo nelas a elaboração da Lei Orgânica, do Plano Diretor e demais competências do Município.

As seções III, IV e V versam sobre a Lei Orgânica Municipal, Orçamento e Controle, e Participação Popular na Administração Municipal, respectivamente, e serão comentadas no trabalho à luz dos documentos produzidos no Município de Feira de Santana.

A Constituição Estadual refere-se, ainda, aos Municípios no Capítulo IV, discorrendo sobre a possibilidade de intervenção do Estado no Município, quando não forem cumpridas as exigências financeiras do orçamento, mediante representação do Tribunal de Contas dos Municípios, por não aplicação das exigências constitucionais, para manutenção do ensino fundamental, ou por representação do Tribunal de Justiça, para assegurar os princípios constitucionais.

Em 5 de abril de 1990, a Câmara Municipal de Feira de Santana promulgou a Lei 37/1990, ou seja, a Lei Orgânica do Município de Feira de Santana e dá outras providências.

Essa Lei reforça os preceitos constitucionais, federais e estaduais e dispõe sobre as questões específicas do Município, como:

- a criação de Leis, símbolos municipais e datas comemorativas do município;

- estabelecimento das bases para normalizar o Código de Polícia Administrativa de Feira de Santana e do Plano Diretor de Desenvolvimento Urbano de Feira de Santana (PDDU);

- implementação da administração pública incluindo os servidores e os serviços públicos;

- organização dos Poderes Legislativo e Executivo;

- disposições sobre tributação e orçamento;

- disposições sobre a ordem econômica e social. Nesta última inclui-se a Saúde; 
- a Assistência Social, a Educação; a Ciência e Tecnologia; a Cultura Esporte e Lazer; o Meio Ambiente; o Saneamento Básico; Assistência aos deficientes, Crianças e Idosos; o Transporte Urbano; a Segurança Pública; o Abastecimento; a Habitação.

Ressalta-se, conforme ASSIS (1988), que a discussão e aprovação dessa lei se deu por iniciativa do legislativo municipal e com a participação de algumas lideranças locais, sem contar, efetivamente, com a participação da sociedade civil organizada.

A elaboração da Lei Orgânica, além de se configurar como um dos principais meios do Município exercer sua autonomia, fixa as principais diretrizes para gestão e planejamento das ações do Município, deixando claro, no capítulo das competências do Município, a provisão de tudo que diga respeito ao seu interesse, tendo como objetivos o pleno desenvolvimento de suas funções sociais e a garantia de bem-estar dos seus habitantes.

No capítulo da ordem econômica e social, a presente pesquisa enfoca as competências do Município nas áreas de educação, saúde, ação social meio ambiente, e fortalece a ligação entre qualidade de vida e a exigência de investimentos sociais para o bem-estar da população, garantidos por meio de políticas públicas.

O ponto de partida, para a análise dos dados, foram foi a Lei Orgânica do Município que está representada no Quadro 4. 


\begin{tabular}{|c|c|}
\hline ÁREAS & COMPETÉNCIAS DO MUNICÍPIO \\
\hline Educação & $\begin{array}{l}\text { Disposições Gerais - Proporcionar os meios de acesso à } \\
\text { cultura, à educação e à ciência. } \\
\text { Art.134 - A educação é direito de todos, dever do poder } \\
\text { público e sociedade, tem como objetivo o pleno } \\
\text { desenvolvimento do cidadão, tornando-o capaz de refletir } \\
\text { criticamente sobre a realidade e qualificado para o trabalho. }\end{array}$ \\
\hline Saúde & $\begin{array}{l}\text { Art. } 128 \text { - O Município integra com a União e o Estado o } \\
\text { Sistema Único de Saúde, cujas ações e serviços públicos, na } \\
\text { sua circunscrição territorial, serão por ele dirigidos. }\end{array}$ \\
\hline Meio Ambiente & $\begin{array}{l}\text { Disposições Gerais - Proteger o meio ambiente e combater a } \\
\text { poluição em qualquer de suas formas. Preservar a fauna e a } \\
\text { flora. } \\
\text { Art. } 157 \text { - Todos têm direito ao maio ambiente ecológico } \\
\text { equilibrado, bem de uso comum do povo e essencial à sadia } \\
\text { qualidade de vida, impondo-se ao poder público e à } \\
\text { comunidade o dever de defendê-lo e preservá-lo para as } \\
\text { presentes e futuras gerações. }\end{array}$ \\
\hline
\end{tabular}

Fonte - Lei Orgânica do Município de Feira de Santana - 2000.

As competências descritas na Lei Orgânica do município de Feria de Santana, nas áreas de educação, saúde e meio ambiente, provêm de exigências contidas na Constituição do Estado da Bahia de 1989 e na Constituição Federal de 1988.

A Lei Orgânica municipal mantém coerência com os preceitos constitucionais, o que indica que o Município poderá aproveitar os benefícios provenientes de programas nacionais, mas a aplicação local de tais programas dependerá da organização e das condições locais para sua implementação.

No primeiro capítulo da Lei Orgânica do Município (Das Disposições Preliminares) está explicitada a responsabilidade do poder público municipal de proporcionar a população as condições de vida compatíveis com a dignidade humana, a justiça social e o bem comum.

O preceito acima referido é coerente com as idéias defendidas por SEN (2002) sobre o processo de desenvolvimento humano, influenciado pelo potencial das múltiplas liberdades de direitos de cidadania, acessíveis a todas as pessoas. E que 
tanto o Estado quanto a sociedade possuem amplos papéis no fortalecimento das capacidades humanas que resultarão em melhores níveis de qualidade de vida.

Entende-se a Lei Orgânica como orientadora das políticas públicas, tendo em vista a melhor qualidade de vida para a população, mas a efetivação dessas diretrizes legais na prática, dependerá de fatores políticos, econômicos e, sociais e nessa área, da capacidade de mobilização social dos diversos grupos que compõem a sociedade.

Nesse percurso, é preciso considerar que a conquista de melhores níveis de qualidade de vida se dá de forma diferenciada nos diversos grupos sócioeconômicos, produzindo nesses grupos o aparecimento de riscos e potencialidades características de cada grupo (BREILH e GRANDA 1996).

Isso fortalece, ainda mais, os papéis do Estado e da sociedade como provedores e controladores da qualidade de vida das pessoas e da coletividade.

O Quadro 4 explicita algumas competências do município contidas na Lei Orgânica: Na área de educação: "a educação é direito de todos, dever do poder público e sociedade...". Para que este seja um direito universalizado, é preciso que integre as políticas públicas nos vários níveis de governo. Isto pode ser evidenciado na fala de um dos secretários do Município:

“... nós percebemos que, a nível das três esferas públicas, federal, estadual e municipal há um olhar, realmente, hoje, diferenciado e cuidadoso para o ensino fundamental, todos estão olhando com muito zelo". (Ent. n 5).

Em função da grande dívida social da educação, evidenciada no país e referida por SAVIANI (1998), talvez o município de Feira de Santana necessite de estratégias, envolvendo os meios de comunicação e outros setores da sociedade para se alcançar a acessibilidade universal à educação.

A busca dessa acessibilidade ainda está restrita à educação fundamental estando esta prioritariamente a cargo da administração municipal.

$\mathrm{Na}$ área da saúde: "o Município integra, com a União e o Estado, o Sistema Único de Saúde”, de acordo com a Lei Orgânica Municipal, e todos os secretários do município que fizerem referência ao sistema de saúde local enfatizaram a necessidade de se avançar para a gestão plena do sistema de saúde, como pode ser constatado nesta fala: 
"O Município de Feira, hoje, está na municipalização plena das ações básicas de saúde e nós estamos dando entrada, esta semana, na solicitação da gestão plena" (Ent. nº 8 ).

A municipalização da saúde consiste em mudança de concepção e postura, como se percebe nos pressupostos teóricos da dissertação de ASSIS (1998) sobre o processo de municipalização da saúde em Feira de Santana:

-"o entendimento de que a municipalização dos serviços de saúde, como um movimento que tem raízes histórico sociais relacionadas à intervenção do Estado através de políticas sociais" (p.31);

- "a configuração organizativa dos serviços de saúde leva em consideração que as relações sociais, estabelecidas entre os diferentes interlocutores que produzem serviços de saúde, devem ser compreendidas a partir de conflitos e interesses diferenciados entre os sujeitos políticos sociais" (p.31);

- "a municipalização concebida como um processo de descentralização, contraria os princípios neoliberais, que têm como argumentação a eficiência e eficácia do gasto, com a interação no nível local, dos recursos públicos e não governamentais, para o financiamento das atividades sociais, numa lógica privada de produção e operação dos serviços" (p.32);

- “a governabilidade ampla do município, enquanto instrumento de poder só pode ser pensada e entendida a partir de um modelo assistencial de saúde integrado, hierarquizado, regionalizado e intercomplementar" (p.32).

Entretanto, a concepção do sistema de saúde local, na fala dos secretários, parece continuar centrada no modelo fragmentado e privatista em que é enfocado, preferencialmente a produtividade dos programas desenvolvidos, como se observa na fala de um dos entrevistados:

“.. 20 programas congregam um universo não inferior a 1100 pessoas, que fazem parte de um exército que é responsável pela melhoria dos indicadores sociais em nossa cidade". (Ent. $n^{\circ} 8$ ).

A área do meio ambiente é valorizada na Lei Orgânica do Município, também com base nas legislações estadual e federal:

"Todos têm direito ao meio ambiente ecológico equilibrado, bem de uso comum do povo e essencial à sadia qualidade de vida..." 
Entretanto, não há uma política clara de financiamento, tendo em vista os baixos percentuais de dotação orçamentária nessa área, conforme o Quadro 13, o que dificulta a implementação das ações, como se verifica no discurso do secretário:

“... o cara apresenta o projeto, coloca debaixo do braço e vai ao Ministério do Meio Ambiente e mostra ao governo que está poluindo a Praia do Forte, onde só tem gringo e aí vamos atrás" (Ent. n4).

Nessa área, a Organização Mundial da Saúde (OMS) e a Organização PanAmericana de Saúde vêm promovendo eventos internacionais, valorizando os seres humanos como centro das preocupações do desenvolvimento sustentável, incluindo a atenção primária do meio ambiente, a saúde e a educação de crianças e adultos, (OMS 1999).

As áreas temáticas enfocadas no Quadro 4 são aquelas que, historicamente, detêm o maior orçamento do Município, como se pode verificar no Quadro 13 na página 92. No entanto, observa-se que a área de meio ambiente sofre a maior oscilação orçamentária.

Nota-se, também, que há uma preocupação do executivo municipal com a alocação de recursos na área social, registrada n seguinte depoimento:

“... nosso orçamento priorizou a parte social em mais de 100 milhões de reais: área de educação, área de saúde e ação social. No orçamento de 182 milhões, mais de 110 milhões é na área social. Então, são algumas ações que nós estamos implementando, está no plano diretor e nós estamos buscando adequar com o estatuto da cidade para melhorar a qualidade de vida das pessoas. Esse é o grande objetivo, tornar Feira habitável". (Ent. $\left.n^{\circ} 4\right)$.

Com essa fala de um dos secretários poder-se-ia inferir que, hoje, o Município de Feira de Santana tenta promover investimentos de acordo com as diretrizes contidas na Lei Orgânica, com o objetivo de melhorar a qualidade de vida local. Considerando a área social, as rubricas representadas no Quadro 4 - Educação; Cultura; Esporte e Lazer; Saúde; Desenvolvimento Urbano e Social; Desenvolvimento Urbano e Meio Ambiente; Desenvolvimento Econômico e Serviços Públicos - poder-se dizer que a área social representa $74 \%$ do orçamento total do município no ano de 2002. 
$\mathrm{Na}$ análise e discussão sobre o Quadro 4 percebe-se que a Lei Orgânica, como orientadora das políticas públicas, mantém coerência com as políticas públicas preconizadas nas Constituições Federal e Estadual, e com as necessidades da população local; tais políticas porém, ainda não estão efetivadas na prática.

A dotação orçamentária para a área social poderá influenciar a efetivação das políticas públicas e conseqüentemente o índice de desenvolvimento humano do Município, ainda que essa influência não produza efeitos imediatos.

\subsection{As políticas públicas e o índice de desenvolvimento humano em Feira de Santana}

Um pressuposto implícito, na presente investigação consiste na compreensão das políticas públicas como um espaço de tomada de decisão dos atores governamentais, que são responsáveis pela execução das ações (COSTA 1998). Nessa situação, o poder executivo está representado pelos secretários municipais, e o Índice de Desenvolvimento Humano poderá ser um reflexo ou uma conseqüência do investimento do município na implementação de determinadas políticas públicas.

O presente trabalho não se propõe a realizar uma avaliação das políticas públicas implementadas no Município se Feira de Santana, mas aproximar a relação existente entre os índices de desenvolvimento humano relativos a dados das décadas 70, $80 \mathrm{e}$ 90 à aplicação do orçamento na década passada, e as ações que estão sendo desempenhadas para viabilizar as políticas públicas.

No Quadro 5 apresenta-se o IDH de Feira de Santana em 3 três décadas.

\section{Quadro 5 - Índice de Desenvolvimento Humano (IDH) de Feira de} Santana - Bahia, nos anos de 1970, 1980, 1991

\begin{tabular}{c|c|c|c}
\hline Índice / Ano & 1970 & 1980 & 1991 \\
\hline IDH - M & 0,409 & 0,596 & 0,644 \\
\hline Longevidade & 0,369 & 0,517 & 0,619 \\
\hline Educação & 0,452 & 0,546 & 0,636 \\
\hline Renda & 0,407 & 0,725 & 0,677 \\
\hline
\end{tabular}

Fonte: pnud/ipea/fjp/ibge 
Ao analisar o Quadro 5, nota-se que há evolução positiva de todos os indicadores do índice de desenvolvimento humano do Município de Feira de Santana, com exceção dos relacionados com a renda que, após uma elevação superior aos demais, nos anos de 1980, sofre queda em relação a 1990.

\begin{tabular}{|c|c|c|c|}
\hline \multicolumn{4}{|c|}{$\begin{array}{c}\text { Quadro } 6 \text { - Indice de Condições de Vida (ICV) em Feira de Santana - } \\
\text { Bahia, nos anos de 1970,1980, 1991 }\end{array}$} \\
\hline Índice / Ano & 1970 & 1980 & 1991 \\
\hline ICV & 0,468 & 0,611 & 0,662 \\
\hline Longevidade & 0,426 & 0,609 & 0,715 \\
\hline Educação & 0,371 & 0,467 & 0,565 \\
\hline Infantil & 0,589 & 0,597 & 0,651 \\
\hline Renda & 0,536 & 0,727 & 0,665 \\
\hline Habitação & 0,420 & 0,654 & 0,711 \\
\hline
\end{tabular}

Fonte: pnud/ipea/jjp/ibge

Com referência à análise dos dados do Quadro 6, referentes aos índices de condições de vida do Município de Feira de Santana, embora haja variação nos valores dos índices observados, constata-se, que há evolução positiva de todos os índices, com exceção daqueles relacionados à renda, que decresce em 1990, como se observou também no Quadro anterior.

O Índice de Desenvolvimento Humano (IDH) é um indicador elaborado pela Organização das Nações Unidas (ONU), e mede a qualidade de vida de 174 países.

Este indicador se baseia no Produto Interno Bruto (PIB) per capita, na saúde (esperança de vida ao nascer) e na educação (matrículas escolares e alfabetização).

Após a apuração desses dados, é feita uma média geral e transformados em índices que variam de zero a um, sendo considerados altos aqueles acima de 0,800, médios, os índices situados entre 0,500 e 0,799, e baixos, entre 0,254 e 0,499.

De acordo com os dados apresentados nos Quadros 5 e 6, que são calculados por metodologia semelhante, percebe-se que o índice de desenvolvimento humano (IDH) para o Município de Feira de Santana, encontra-se em médio desenvolvimento 0,644 no ano de 1991, enquanto o IDH do Brasil era, no mesmo período, 0,708 e, em $1997,0,739$. 
Dados do Programa das Nações Unidas para o Desenvolvimento (PNUD 1999), ao permitir um paralelo entre Brasil e Polônia, países com renda per capita aproximada, o primeiro com 6.480 dólares, e o segundo com 6.420 dólares, mostram os dados do PNUD que o Brasil e Polônia se distanciam quando são computados os percentuais relacionados à educação, o primeiro com $84 \%$ e o segundo com $99 \%$ e os dados de esperança de vida ao nascer, o primeiro com 66,8 anos e o segundo com 75,5 anos, resultando num IDH para o Brasil, em 1997, de 0,739, na faixa de médio desenvolvimento, e a Polônia com um IDH de 0,802, na faixa de alto desenvolvimento.

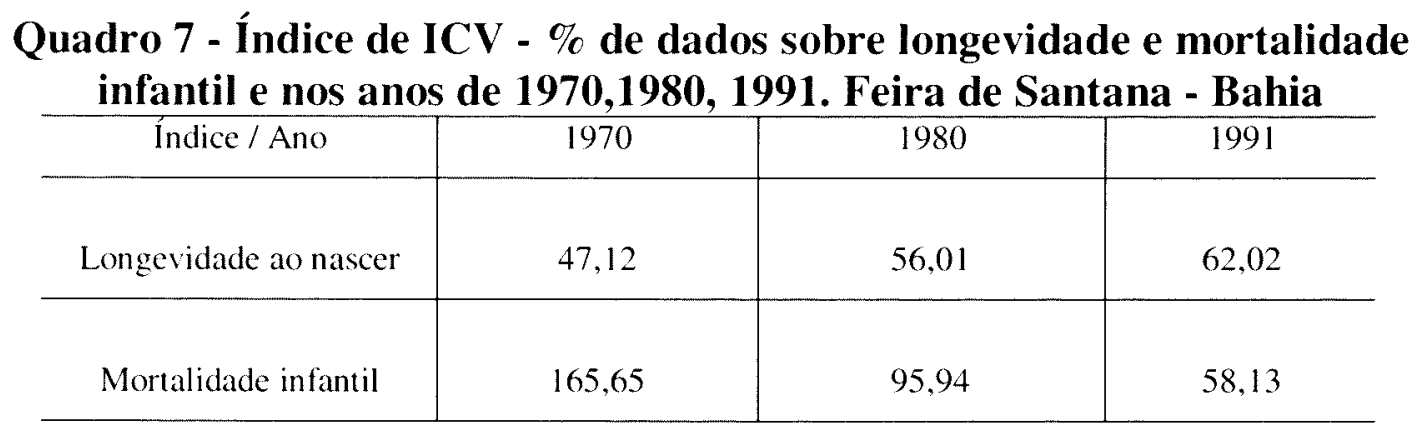

Fonte: pnud/ipea/jjp/ibge

No Quadro 7, percebe-se uma evolução favorável, tanto do índice de longevidade ao nascer, como de índice mortalidade infantil, e continuam evoluindo, passando o primeiro de 62 para 66 anos, referente ao ano de 1996 de acordo com dados do sistema de informação de Saúde da Secretaria de Saúde do estado da Bahia.

De acordo com dados do DATASUS no ano de 1996 a esperança de vida para o Município de Salvador, situado a $108 \mathrm{~km}$. de Feira de Santana é de 64,10 e 70,33 para homens e mulheres respectivamente (BARBONI 2002).

De acordo com dados do Ministério da Saúde sobre de esperança de vida ao nascer para o Brasil em 1998 é de 64 anos para homens e 72 anos para mulheres, para o Nordeste, 62 anos para homens e 68 anos para mulheres e para a Bahia, 64 anos para homens e 70 anos para mulheres. (BRASIL IDB 98).

E os dados de mortalidade infantil de 58,13 para 21,70 mortes de crianças por mil nascidos vivos. Esses índices são provenientes de pesquisa realizada em Feira de Santana com crianças menores de 5 anos de idade, no ano de 2002 (ALMEIDA KB 2002). 
De acordo com dados do Ministério da saúde a taxa de mortalidade infantil para menores de um ano referente ao ano de 1997 é de 14,9 para o Brasil, 26,4 para o Nordeste e de 21,9 para a Bahia.

Vale salientar que os dados de mortalidade infantil no Nordeste são os mais altos do Brasil e que a Bahia apresenta taxas mais elevadas que Piauí e Sergipe.

\section{Quadro 8 - Índice e ICV - \% de dados sobre educação nos anos de 1970,} 1980, 1991. Feira de Santana - Bahia

\begin{tabular}{c|c|c|c}
\hline Índice / Ano & 1970 & 1980 & 1991 \\
\hline Menos de 4 anos de estudo & 73,1 & 59,5 & 43,6 \\
\hline Menos de 8 anos de estudo & 92,8 & 83,2 & 69,7 \\
\hline Mais de 11 anos de estudo & 0,55 & 2,82 & 4,47 \\
\hline Taxa de analfabetismo de 15 & & & 20,9 \\
\hline anos e mais & 39,3 & 29,0 & 4,9 \\
\hline
\end{tabular}

Fonte: pnud/ipea/fjp/ibge

No Quadro 8, observa-se que os índices de educação são desfavoráveis, sendo os de analfabetismo os que chamam mais a atenção, pela pequena queda que apresentam entre a década de 1980 e 1990 . Esses índices se mantêm altos na Bahia como um todo, que atinge, atualmente, $20 \%$, índice inferior ao do Nordeste, que é de $21,75 \%$, considerando que o índice de analfabetismo para o Brasil é de 11,4\% (IBGE 1999).

A dificuldade para manter a criança na escola foi comprovada por um dos secretários do município:

“A criança ainda está se evadindo muito fácil, nem a merenda escolar está prendendo mais”. (Ent. no 5).

A evasão escolar pode ser influenciada por diversos fatores, como aqueles referentes à qualidade do ensino, ou relacionados com as condições sócioeconômicas dos alunos, o que, muitas vezes, concorre para que eles tenham que trabalhar na idade escolar. 


\begin{tabular}{|c|c|c|c|}
\hline $\begin{array}{c}C c^{a} \text { de } 7 \text { a } 14 \text { a fora da } \\
\text { escola }\end{array}$ & 29,1 & 30,1 & 28,8 \\
\hline Defasagem escolar $10 / 14$ & 2,9 & 2,8 & 2,6 \\
\hline $\begin{array}{l}\text { Mais de um ano de atraso- } \\
\qquad 10 / 14\end{array}$ & 74,1 & 73,6 & 70,2 \\
\hline $\begin{array}{c}\% \text { de } C c^{\mathrm{a}} \mathrm{s} \text { que trabalham - } \\
10 / 14\end{array}$ & 15,4 & 7,5 & 7,3 \\
\hline
\end{tabular}

Fonte: pnud/ipea/jjp/ibge

No Quadro 9, o índice que mais chama a atenção é o percentual de 28,8\% de crianças de 7 a 14 anos fora da escola, o que pode ser traduzido, na atualidade por um número ainda maior de analfabetos, do que os $20 \%$ referidos no Quadro 8.

Os dados apresentados nos quadros 8 e 9, nos quais encontram-se os índices referentes a educação, indicam altos percentuais de analfabetismo e de pessoas com menos de 8 anos de estudo, além de defasagem entre idade e série na faixa etária de 7 a 14 anos. A esses índices somam-se os altos índices de pobreza e baixas condições de moradia verificados nos Quadros 10 e 11.

Para o PNUD (1996), a educação aparece como condição fundamental para o desenvolvimento, além de promover valores éticos; como tal o sistema educacional brasileiro deve ser reformado, para propiciar uma educação básica de qualidade, e o combate à pobreza, no sentido da construção da cidadania plena.

Isto é reforçado por PINTO (1976), ao afirmar que existe uma relação direta entre o nível de educação, redistribuição de renda, e de que as possibilidades de as pessoas alcançarem melhor educação estão condicionadas à renda familiar. 
Quadro 10 - Índice de ICV - \% de dados sobre renda nos anos de 1970, 1980, 1991. Feira de Santana - Bahia

\begin{tabular}{c|c|c|c}
\hline$\% /$ Ano & 1970 & 1980 & 1991 \\
\hline Renda per ćppita média & 0,58 & 1,0 & 0,94 \\
\hline Grau de desigualdade & 0,53 & 0,53 & 0,68 \\
\hline Renda insuficiente & 70,12 & 45,45 & 55,00 \\
\hline Insuficiência média & 0,36 & 0,20 & 0,28 \\
\hline $\begin{array}{c}\text { Grau de desig. p/ pop. c/ } \\
\text { média insuficiente }\end{array}$ & 0,23 & 012 & 0,18 \\
\hline
\end{tabular}

Fonte: pnud/ipea jjp/ibge

No Quadro 10, observa-se queda na renda per capita média, seguida pela queda do grau de desigualdade entre 1980, seguido de aumento em 1991.

Quadro 11 - Índice de ICV - \% de dados sobre habitação nos anos de 1970, 1980, 1991. Feira de Santana - Bahia.

\begin{tabular}{c|c|c|c}
\hline$\% /$ Ano & 1970 & 1980 & 1991 \\
\hline $\begin{array}{c}\text { Densidade sup a 2 } \\
\text { pessoas/dorm. }\end{array}$ & 46,9 & 44,9 & 32,1 \\
\hline $\begin{array}{c}\text { Matérial de const. } \\
\text { Durável }\end{array}$ & 86,7 & 94,5 & \\
\hline $\begin{array}{c}\text { Abastecimento adeq. } \\
\text { de água }\end{array}$ & 24,2 & 63,5 & 73,6 \\
\hline $\begin{array}{c}\text { Disponibilidade de } \\
\text { esgoto }\end{array}$ & 40,2 & 48,2 & 45,9 \\
\hline
\end{tabular}

Fonte: pnud/ipea jjp/ibge

No Quadro 11, referente ao Índice de condições de vida sobre habitação, percebe-se uma diminuição no índice referente à cobertura de esgoto.

De acordo com dados das entrevistas, esse índice pode ser ainda menor, hoje: 
"Feira é uma cidade que tem apenas 30 ou $40 \%$ de esgoto sanitário. A nossa idéia é cobrir nesses 3 anos para que cheguemos a 80 ou $90 \% "$. (Ent n 4$)$.

As informações da entrevista $\mathrm{N}^{\circ} 4$ indicam que o déficit de cobertura de esgoto tende a aumentar, considerando o aumento da população na última década e os baixos investimentos em esgotamento sanitário.

Os dados do Quadro 10, de renda, e do Quadro 11, sobre habitação, são indicadores do índice de pobreza da população, principalmente quando se compara o grau de desigualdade desde a década de 1970.

Embora o Brasil tenha apresentado um alto crescimento na década de 1970 que, de acordo com BARROS (2000), é ingrediente fundamental para diminuição da pobreza, mas com efeito muito lento, quando não é acompanhada da diminuição do grau de desigualdade.

Nos últimos 20 anos, há dois momentos de queda do nível de pobreza no País em 1986, com o lançamento do Plano Cruzado, que foi de $28 \%$, e em 1995, com o Plano Real, que foi de $34 \%$ (BARROS 2000).

Esses índices ainda são considerados altos, e o pesquisador acima referido afirma que a pobreza no Brasil não está ligada à escassez de recursos.

Pode-se, portanto, inferir que a questão da pobreza pode ter solução no âmbito das políticas públicas, cabendo à administração pública, com a participação da sociedade civil organizada, a responsabilidade de gerir os recursos públicos e aqueles provenientes de fontes privadas e do terceiro setor.

Na atuação do terceiro setor, FERNANDES (1994) refere que a observância dos direitos de cidadania são essenciais para sustentação das organizações não governamentais.

Entende-se que o equilíbrio da correlação de forças entre poder público e sociedade é fundamental nas decisões, e que os direitos de cidadania, civis, políticos e sociais conquistados têm importante papel na alocação de recursos para financiamento das políticas públicas.

Um dos principais méritos de Marshall (SANTOS 1997 citado por SANCHES FILHO 1998), consiste em articular cidadania e classe social, para caracterizar as relações entre cidadania e capitalismo. 


\subsection{O Orçamento anual do Município e o financiamento das políticas públicas}

Apesar da complexidade e do tecnicismo inerentes à elaboração do orçamento público, TEIXEIRA (2000) cita algumas experiências na região de Feira de Santana - Bahia, desenvolvidas em 1992 pelo Movimento de Organização Comunitária (MOC), através de cursos a lideranças e do acompanhamento nas comunidades envolvendo o levantamento de prioridades e elaboração de emendas, bem como mobilização para audiência pública com o executivo municipal ou o presidente da Câmara de Vereadores. O autor ainda refere que, durante a elaboração da Lei Orgânica do município de Feira de Santana, o Movimento de Organização Comunitária (MOC) registrou dificuldades na participação da sociedade civil organizada nos debates.

O exercício da liberdade de participação, influenciado por discussões públicas e interações sociais defendido por SEN (2002), pode aproximar a sociedade das decisões na dotação orçamentária, de acordo com as necessidades sociais, que, por sua vez, implica em compartilhar poder, residindo aí a maior dificuldade.

O orçamento municipal, de acordo com a Lei Orgânica do Município, tem a previsão de despesas explicitadas em documento público, e sua execução deve ser publicada a cada bimestre, após trinta dias de ser executada (artigo 104, parágrafo 3): contudo, ainda assim, não é usual o acompanhamento das contas públicas pela população.

Algumas experiências de gestão participativa vingaram no Brasil, tendo sua origem no movimento democrático da década de 1980, e já se experimenta ampla participação na elaboração da Lei Orgânica, como Porto Alegre, em 1990, que inaugura uma inovação que merece destaque a discussão pública do orçamento municipal - "Orçamento Participativo", que vem sendo desenvolvido desde 1989 e se modificando a cada ano (MOURA 1993).

Seria oportuno que movimento semelhante se desse em Feira de Santana, para aproximar as necessidades sentidas pela população das decisões políticas sobre destinação de recursos. Ver evolução do orçamento do Municipal (Quadros 12 e 13). 
Quadro 12 Evolução do Orçamento Público do Município de Feira de Santana de 1993 a 2002

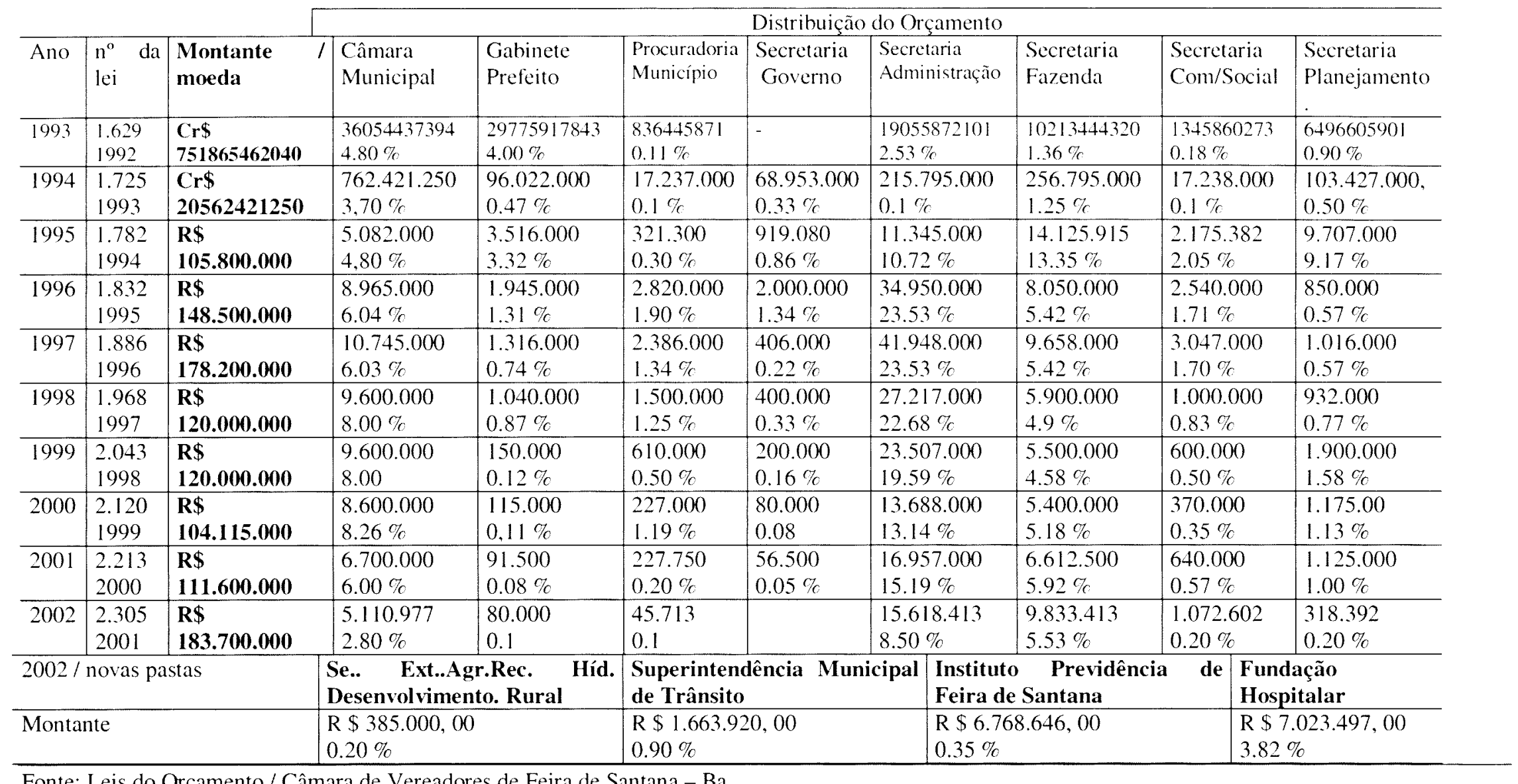

Fonte: Leis do Orçamento / Câmara de Vereadores de Feira de Santana - Ba. 
Quadro 13 Evolução do Orçamento Público do Município de Feira de Santana de 1993 a 2002 (cont.)

\begin{tabular}{|c|c|c|c|c|c|c|c|c|c|c|}
\hline \multirow[b]{2}{*}{ ano } & \multirow[b]{2}{*}{$\begin{array}{l}N^{\circ} \text { da } \\
\text { lei }\end{array}$} & \multirow[b]{2}{*}{$\begin{array}{l}\text { Montante } \\
\text { moeda }\end{array}$} & \multicolumn{8}{|c|}{ Distribuição do Orçamento } \\
\hline & & & $\begin{array}{l}\text { Secretaria } \\
\text { Educação }\end{array}$ & $\begin{array}{l}\text { Séc.Cultura } \\
\text { Esp. Lazer }\end{array}$ & $\begin{array}{l}\text { Secretaria } \\
\text { Saúde }\end{array}$ & $\begin{array}{l}\text { Sec.Desen. } \\
\text { Social }\end{array}$ & $\begin{array}{l}\text { Sec. Meio } \\
\text { Ambiente }\end{array}$ & $\begin{array}{l}\text { Sec.Dese. } \\
\text { Econômico }\end{array}$ & $\begin{array}{l}\text { Sec. Serv. } \\
\text { Públicos }\end{array}$ & $\begin{array}{l}\text { Reserva } \\
\text { Contingencia }\end{array}$ \\
\hline 1993 & $\begin{array}{l}1.629 \\
1992\end{array}$ & $\begin{array}{l}\mathrm{Cr} \$ \\
751865462040\end{array}$ & $\begin{array}{l}\text { Cult / esporte } \\
125697349036 \\
17 \%\end{array}$ & $\begin{array}{l}\text { Sec.Abastec. } \\
3899221354 \\
0.52 \%\end{array}$ & $\begin{array}{l}84895720385 \\
11,30 \%\end{array}$ & $\begin{array}{l}\text { SecAgricultura } \\
6691566968 \\
0.90 \%\end{array}$ & $\begin{array}{l}\text { Sec. Obras } \\
323642052447 \\
43.05 \%\end{array}$ & $\begin{array}{l}4616174957 \\
0.61 \%\end{array}$ & $\begin{array}{l}33.34463164 \\
3 \\
4.43 \%\end{array}$ & $\begin{array}{l}38376667000 \\
0.51 \%\end{array}$ \\
\hline 1994 & $\begin{array}{l}1.725 \\
1993\end{array}$ & $\begin{array}{l}\mathrm{Cr} \$ \\
20562421250\end{array}$ & $\begin{array}{l}5.422 .676 .000 \\
26.37 \%\end{array}$ & $\begin{array}{l}344.761 .000 \\
1.68 \%\end{array}$ & $\begin{array}{l}1.611 .615 .000 \\
7.85 \%\end{array}$ & $\begin{array}{l}1.233 .745 .270 \\
6.00 \%\end{array}$ & $\begin{array}{l}\text { Sec. Obras } \\
6.224 .276 .730 \\
30.27 \%\end{array}$ & $\begin{array}{l}\text { Sec.Ind.Com } \\
\text { Turismo } \\
27.582 .000 \\
0.13 \%\end{array}$ & $\begin{array}{l}155.144 .000 \\
0.75 \%\end{array}$ & $\begin{array}{l}4.005 .338 .00 \\
0 \\
19.48 \%\end{array}$ \\
\hline 1995 & $\begin{array}{l}1.782 \\
1994\end{array}$ & $\begin{array}{l}\mathrm{R} \$ \\
105.800 .000\end{array}$ & $\begin{array}{l}26.450 .731 \\
25,00 \%\end{array}$ & $\begin{array}{l}3.220 .000, \\
3.04 \%\end{array}$ & $\begin{array}{l}10.580 .000, \\
9.90 \%\end{array}$ & $\begin{array}{l}2.347 .821 \\
2.21 \%\end{array}$ & $\begin{array}{l}\text { Sec. Obras } \\
5.189 .190 \\
4.90 \%\end{array}$ & $\begin{array}{l}\text { Sec.Ind.Com } \\
\text { Turismo } \\
1.669 .500 \\
1.57 \%\end{array}$ & $\begin{array}{l}7.595 .122 \\
7.17 \%\end{array}$ & $\begin{array}{l}1.554 .488 \\
1.46 \%\end{array}$ \\
\hline 1996 & $\begin{array}{l}1.832 \\
1995\end{array}$ & \begin{tabular}{|l|}
$R \$$ \\
148.500 .000 \\
\end{tabular} & $\begin{array}{l}40.850 .000 \\
27.50 \%\end{array}$ & $\begin{array}{l}5.170 .000 \\
3.48 \%\end{array}$ & $\begin{array}{l}16.640 .000, \\
12.20 \%\end{array}$ & \begin{tabular}{|l|}
4.200 .000 \\
$2.82 \%$ \\
\end{tabular} & $\begin{array}{l}7.460 .000, \\
5.02 \%\end{array}$ & $\begin{array}{l}3.040 .000 \\
2.04 \%\end{array}$ & $\begin{array}{l}7.020 .000 \\
4.72 \%\end{array}$ & $\begin{array}{l}2.000 .000 \\
1.35 \%\end{array}$ \\
\hline 1997 & $\begin{array}{l}1.886 \\
1996 \\
\end{array}$ & \begin{tabular}{|l|}
$\mathrm{R} \$$ \\
178.200 .000 \\
\end{tabular} & $\begin{array}{l}49.022 .000 \\
27.50 \%\end{array}$ & $\begin{array}{l}6.201 .000 \\
3.47 \%\end{array}$ & $\begin{array}{l}20.976 .000 \\
11.77 \%\end{array}$ & \begin{tabular}{|l|}
7.043 .000 \\
$3.95 \%$ \\
\end{tabular} & $\begin{array}{l}8.945 .000 \\
5.01 \%\end{array}$ & $\begin{array}{l}5.653 .000 \\
3.17 \%\end{array}$ & $\begin{array}{l}8.428 .000 \\
7.72 \%\end{array}$ & $\begin{array}{l}1.410 .000 \\
10,79 \%\end{array}$ \\
\hline 1998 & $\begin{array}{l}1.968 \\
1997 \\
\end{array}$ & \begin{tabular}{|l|}
$\mathrm{R} \$$ \\
120.000 .000
\end{tabular} & $\begin{array}{l}36.045 .000 \\
30.03 \%\end{array}$ & $\begin{array}{l}2.700 .000 \\
2.25 \%\end{array}$ & $\begin{array}{l}13.000 .000, \\
10.83 \%\end{array}$ & \begin{tabular}{|l|}
6.823 .000 \\
$5.68 \%$ \\
\end{tabular} & $\begin{array}{l}4.705 .000 \\
3.92 \%\end{array}$ & $\begin{array}{l}1.800 .000 \\
1.50 \%\end{array}$ & $\begin{array}{l}4.928 .000 \\
4.10 \%\end{array}$ & $\begin{array}{l}2.410 .000 \\
2.00 \%\end{array}$ \\
\hline 1999 & $\begin{array}{l}2.043 \\
1998 \\
\end{array}$ & $\begin{array}{l}\mathrm{R} \$ \\
120.000 .000 \\
\end{array}$ & $\begin{array}{l}35.420 .000 \\
29.51\end{array}$ & $\begin{array}{l}1.820 .000 \\
1.51 \%\end{array}$ & $\begin{array}{l}15.489 .000, \\
12.90 \%\end{array}$ & $\begin{array}{l}6.970 .000 \\
5.80 \% \\
\end{array}$ & $\begin{array}{l}9.294 .000 \\
7.74 \% \\
\end{array}$ & $\begin{array}{l}3.750 .000 \\
3.12 \%\end{array}$ & $\begin{array}{l}5.120 .000 \\
4.26 \% \\
\end{array}$ & - \\
\hline 2000 & $\begin{array}{l}2.120 \\
2000\end{array}$ & \begin{tabular}{|l|}
$R \$$ \\
104.115 .000
\end{tabular} & $\begin{array}{l}28.950 .000 \\
27.50 \%\end{array}$ & $\begin{array}{l}601.000 \\
0.58 \%\end{array}$ & $\begin{array}{l}22.276 .000, \\
21.39 \%\end{array}$ & \begin{tabular}{|l|}
3.631 .000 \\
$3.48 \%$ \\
\end{tabular} & $\begin{array}{l}9.612 .000 \\
9.23 \%\end{array}$ & $\begin{array}{l}1.950 .000 \\
1.78 \%\end{array}$ & $\begin{array}{l}7.440 .000 \\
7.15 \%\end{array}$ & - \\
\hline 2001 & $\begin{array}{l}2.213 \\
2000 \\
\end{array}$ & \begin{tabular}{|l|}
$\mathrm{R} \$$ \\
111.600 .000 \\
\end{tabular} & $\begin{array}{l}\text { 30.934.000 } \\
27.71 \%\end{array}$ & $\begin{array}{l}518.500 \\
0.46 \% \\
\end{array}$ & $\begin{array}{l}20.821 .000, \\
18.65 \%\end{array}$ & \begin{tabular}{|l|}
2.686 .750 \\
$2.40 \%$ \\
\end{tabular} & $\begin{array}{l}12.319 .500 \\
10.03 \%\end{array}$ & $\begin{array}{l}1.659 .500 \\
1.49 \%\end{array}$ & $\begin{array}{l}10.250 .000,9 \\
.18 \% \\
\end{array}$ & - \\
\hline 2002 & \begin{tabular}{l|}
2.250 \\
2001 \\
\end{tabular} & \begin{tabular}{|l|}
$R \$$ \\
183.700 .000 \\
\end{tabular} & $\begin{array}{l}33.582 .000 \\
18.28 \%\end{array}$ & $\begin{array}{l}1.926 .813 \\
1.05 \%\end{array}$ & $\begin{array}{l}\text { 62.840.412, } \\
34.20 \%\end{array}$ & $\begin{array}{l}2.164 .628 \\
1.17 \%\end{array}$ & $\begin{array}{l}21.517 .512 \\
11.71 \%\end{array}$ & $\begin{array}{l}2.546 .604 \\
1.38 \%\end{array}$ & $\begin{array}{l}11.201 .54 \\
6.10 \%\end{array}$ & - \\
\hline
\end{tabular}

Fonte: Leis do Orçamento / Câmara de Vereadores de Feira de Santana - Ba. 
O quadro referente à evolução do Orçamento Público de Feira de Santana está enfocado considerando o período de 1993 a 2002, e compreende dois mandatos e meio de quatro anos, sendo que o primeiro mandato, no período de 1993 a 1996 teve a participação de dois prefeitos, em função do afastamento do titular em 1995, para candidatar-se ao Governo do Estado, quando o vice-prefeito assumiu a administração do Município.

O segundo mandato, referente ao período de 1997 a 2000, teve, também, a participação de dois prefeitos, devido ao falecimento do titular em 1997. O terceiro mandato compreende o período de 2001 a 2004, que se encontra na metade do período.

Para análise da previsão orçamentária nos períodos supracitados, será focalizado o compreendido entre 1995 e 2002, a partir da estabilização da moeda, para melhor visualização da variação do orçamento do Município nos últimos sete anos, conforme figura 6.

\section{Figura 6 - Gráfico da evolução do orçamento do Município de Feira de Santana em milhões de reais no período de 1995 a 2002.}

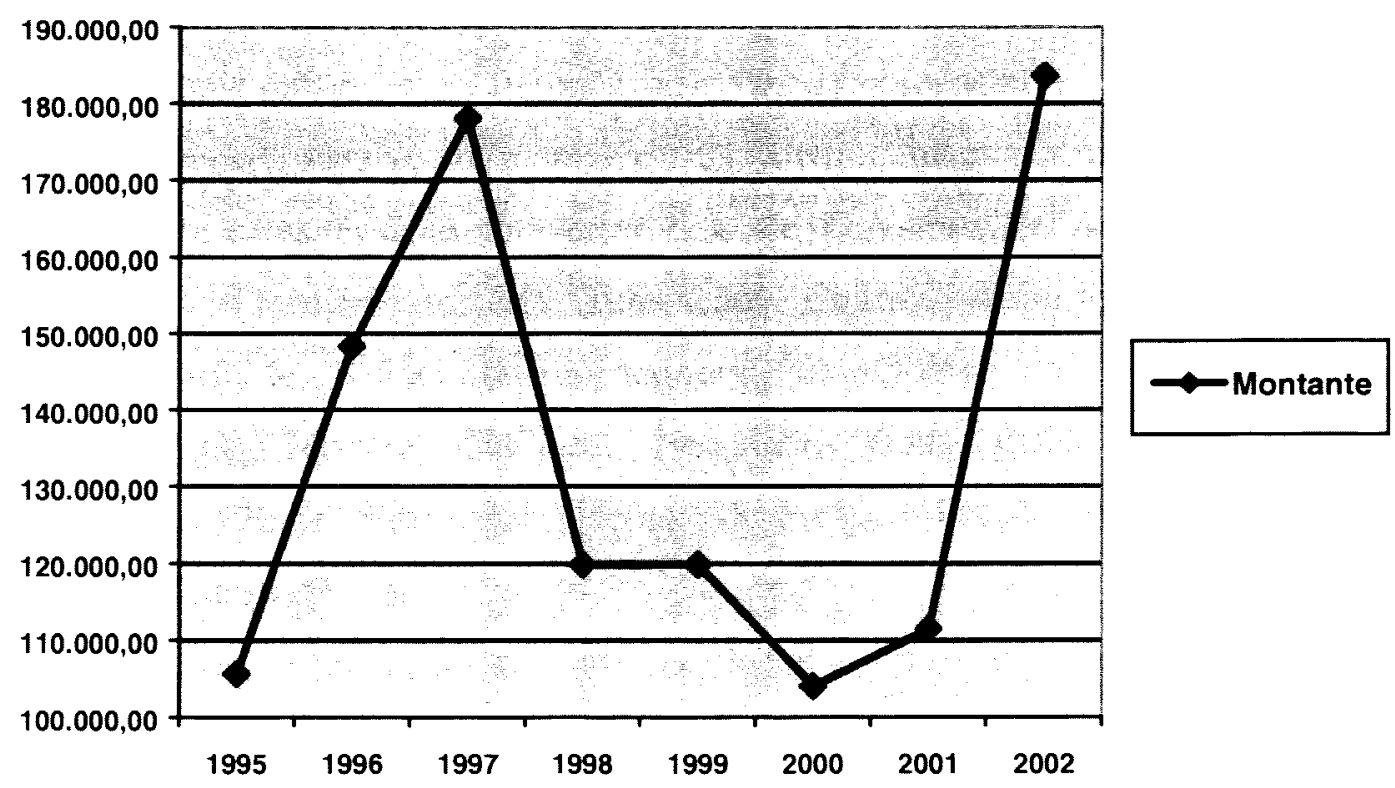

Fonte: Leis Orçamentárias / Câmara de Vereadores de Feira de Santana - Bahia 
A Figura 6 indica que entre 1995 e 2002 a dotação orçamentária do Município oscilou entre $\mathrm{R} \$ 105.800 .000,00$ e $\mathrm{R} \$ 183.700 .000,00$.

Durante o período de 1993 a 2002, há um crescimento orçamentário no período de 1995 a 1997 da ordem de 68,43\%, havendo uma queda no ano de 1998, de $32 \%$, mantém-se estável em 1999 e volta a cair, mais ainda, no ano de 2000, em $12 \%$, voltando a subir em 2001, 6,70\% e, no ano de 2002 ultrapassa o orçamento de 1997, com uma alta na ordem de $64,60 \%$. De acordo com informações de setores ligados ao planejamento e orçamento municipal, esse aumento depende da efetivação da condição de municipalização plena do sistema da saúde, em que se espera um repasse para as ações de média e alta complexidade, que complementará e viabilizará a peça orçamentária em vigor (Figura 6). Essa informação pode ser constatada pelo, fala de um dos secretários do Município:

“... fizemos o orçamento que ele vai estar na "saúde plena" isso implica em 62 milhões de gasto com a saúde..." (Ent. nº 4).

Esse aumento no orçamento da saúde para o Município significa, mais que um aumento de receita, uma mudança na estrutura do sistema municipal de saúde, em que se prevê maior autonomia da Secretaria de Saúde na alocação dos recursos de saúde no município.

Fazendo um retrospecto durante o período de 1993 a 2001, as rubricas do orçamento municipal sofreram algumas variações de nomenclatura. No ano de 1993, no qual cuja moeda vigente era o cruzeiro $(\mathrm{Cr} \$)$, a administração municipal de Feira de Santana funcionava com 13 secretarias: de Governo; de Administração; da Fazenda; do Planejamento; da Educação; Cultura, Esporte e Lazer; de Abastecimento; de Saúde; de Agricultura; de Obras; de Desenvolvimento Econômico, de Serviços Públicos, possuindo ainda mais quatro rubricas orçamentárias: Câmara Municipal, Gabinete do Prefeito; Procuradoria do Município e Reserva de Contingência.

A Secretaria de Obras foi mantida até 1995, e em 1993 apresentou o maior percentual de aplicação orçamentária, 43,05 \%. No ano de 1994 essa secretaria mantém o percentual de $30,27 \%$, configurando-se também, como o maior percentual de aplicação orçamentária do Município. Em 1995, esse percentual cai para 4,90\% e, 
em 1996, essa secretaria é extinta e se cria a Secretaria de Desenvolvimento e Meio Ambiente.

Ainda no ano de 1994, a Secretaria de Abastecimento e a Secretaria de Agricultura são extintas, e há o desmembramento da Secretaria de Educação, da Secretaria de Cultura, Esporte e Lazer, além da criação da Secretaria de Indústria, Comércio e Turismo, que se mantêm nos anos de 1994 e 1995.

Na rubrica de Reserva relativa de Contingência não houve dotação orçamentária nos orçamentos de 1999 a 2002. Da acordo com o inciso III do Artigo $5^{\circ}$ da Lei de Responsabilidade Fiscal, a Reserva de Contingência é destinado ao "atendimento de passivos contingentes e outros riscos e eventos fiscais imprevistos".

A rubrica referente à Câmara Municipal, por força da Emenda Constitucional $n^{\circ}$ 45 de 14/02/2000, não poderá ultrapassar $6 \%$, e isto significa uma redução das transferências feitas para a Câmara de Vereadores, e que vinham sendo feitas em torno de $8 \%$, desde 1998 .

No ano de 2002, foram acrescentadas ao orçamento municipal quatro rubricas: Secretaria Extraordinária da Agricultura, Recursos Hídricos e Desenvolvimento Rural; Superintendência Municipal de Trânsito; Instituto de Previdência de Feira de Santana; e Fundação Hospitalar.

Ao longo dos dez anos analisados, 1993 a 2002, houve uma freqüente variação da dotação orçamentária por rubrica que, para fins de análise, serão dispostas em duas áreas: a primeira será denominada área de infra-estrutura administrativa, legislativa e judiciária, e a segunda, área de abrangência social e de serviços, explicitando os maiores e os menores percentuais de aplicação orçamentária.

A Câmara Municipal teve sua menor dotação no orçamento atual de 2002, pelos motivos anteriormente citados, e teve sua maior dotação no ano 2000, com 8,26\%; o Gabinete do Prefeito teve sua menor dotação em 2002, com 0,1\% e, sua maior dotação em 1995, com 3,32 \%; a Procuradoria do Município contou com seu menor orçamento no período em 2002 e o maior, 1,90, \% em 1995; a Secretaria de Governo não teve dotação em 2002 e o maior orçamento do período foi 1,24 \% em 1996; a Secretaria de Administração teve o menor percentual no orçamento, 0,1 \%, em 1994 e o maior, 23,53 \%, nos anos de 1996 e 1997; a Secretaria da Fazenda teve o menor percentual de orçamento, 1,25\%, em 1994 e o maior, 13,35\%, em 1995; a Secretaria 
de Comunicação Social teve seu menor percentual no orçamento, 0,1\% em 1994 e o maior, 2,05\%, em 1995; e a Secretaria de Planejamento teve o menor percentual de orçamento, 0,20\%, em 2002 e o maior, 9,17\%, em 1995, (Quadro 13).

A segunda área, considerada área de abrangência social e de serviços, engloba a Secretaria de Educação; Secretaria de Cultura, Esporte e Lazer; Secretaria de Saúde; Secretaria de Desenvolvimento e Ação Social; Secretaria de Desenvolvimento e Meio Ambiente; Secretaria de Desenvolvimento Econômico e Secretaria de Serviços Públicos constam do Quadro 13.

Quadro 14 - Dotação orçamentária em percentual, por rubrica, nas áreas de educação, saúde e meio ambiente, entre 1993 e 2002 Feira de Santana - Bahia.

\begin{tabular}{c|c|c|c|c|c|c|c|c|c|c}
\hline $\begin{array}{c}\text { Ano/ } \\
\text { Secretarias }\end{array}$ & 1993 & 1994 & 1995 & 1996 & 1997 & 1998 & 1999 & 2000 & 2001 & 2002 \\
\hline Educação & 17,0 & 26,3 & 25,0 & 27,5 & 27,5 & 30,0 & 29,5 & 27,5 & 27,7 & 18,3 \\
\hline Saúde & 11,3 & 7,85 & 9,90 & 12,2 & 11,7 & 10,8 & 12,9 & 21,39 & 18,6 & 34,2 \\
\hline M.Ambiente & 43,0 & 30,3 & 4,90 & 5,02 & 5,01 & 3,92 & 7,74 & 9,23 & 10,0 & 11,7 \\
\hline
\end{tabular}

Fonte: Leis Orçamentárias / Câmara de Vereadores de Feira de Santana - BA.

Diante da relevância orçamentária que representam as áreas de educação, saúde e meio ambiente e da importância para o objeto de pesquisa, esses temas serão enfocados e discutidos, levando-se em consideração as exigências legais, o investimento orçamentário e as ações desenvolvidas pelo Município, ressaltando-se a realidade e as perspectivas.

As áreas enfocadas tem grande relevância no processo de desenvolvimento humano que, de acordo com SEN (2002), é influenciado pela inter-relação das múltiplas liberdades, sejam estas substantivas, de ter condições de evitar privações, como a fome e a subnutrição, seja a liberdade de saber ler e escrever e de possuir uma moradia digna. 
Figura 7 Gráfico da evolução da dotação orçamentária em percentual, por rubrica, nas áreas de educação, saúde e meio ambiente entre $1993 \mathrm{e}$ 2002 Feira de Santana - Bahia.

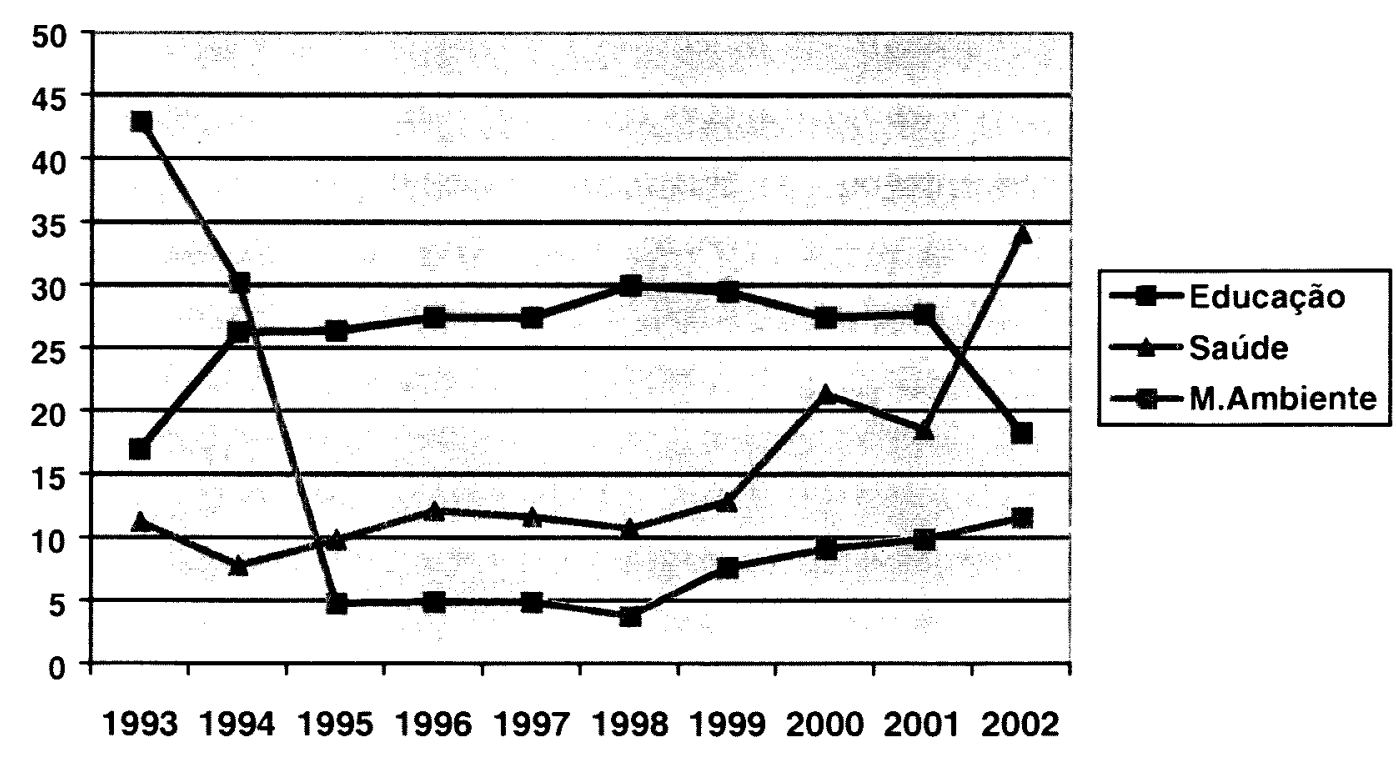

Fonte: Leis Orçamentárias / Câmara de Vereadores de Feira de Santana - BA.

No desenho gráfico da figura 7, estão evidenciados os percentuais de aplicação orçamentária, aproximadamente constante ou em declínio, na área de educação, apesar dos altos índices de analfabetismo e de defasagem entre o ano cursado e a idade das crianças.

Outro dado importante é a queda de investimento orçamentário, entre os anos de 1993 e 1995, na área de meio ambiente, quando esta secretaria era denominada Secretaria de Obras.

Os percentuais de dotações orçamentárias das três áreas enfocadas não se constituem uma ilegalidade constitucional, mas, não são proporcionais às necessidades da população, para que as políticas públicas tenham impacto positivo na vida das pessoas, no sentido da promoção da saúde.

Para a promoção da saúde da comunidade, GREEN and ANDERSON (1986) indicam ser necessário que os setores governamentais de saúde dêem ênfase às ações locais, com a colaboração e esforços de todos os setores públicos e privados. 


\subsection{Política de Educação para o Município de Feira de Santana}

Para se compreender o sistema educacional do Município de Feira de Santana, faz-se necessária uma compreensão histórica do sistema educacional brasileiro e a interferência da visão político-administrativa dos governantes, responsáveis pelos destinos do país no decorrer do Século XX.

No ano de 1900 , dos 9.750 .000 habitantes na faixa etária de 7 a 14 anos, $65 \%$ era de analfabetos, e em 1950, meio século depois, o Brasil apresenta 30.250 .000 habitantes na faixa etária referida, e o percentual de analfabetos cai apenas para $51 \%$. Em números absolutos, o contingente de analfabetos aumentou muito (TEIXEIRA AS 1968).

Anísio Teixeira (1900 a 1971), grande educador baiano, secretário de educação do governo Otávio Mangabeira, um dos grandes entusiastas do movimento da "Escola Nova", defendia a educação como direito, o acesso à educação como forma de diminuir as desigualdades sociais, considerando que a escola deve ser o local onde as pessoas se encontram, como um lugar comum, onde os preconceitos e diferenças não devem ser levados em conta, e se crie amizade e camaradagem entre pessoas das várias classes, propiciando a aproximação social e destruição de preconceitos.

Essa colocações do autor citado alinhavam-se ao seu entendimento de que a educação, na década de 1920 e 1930, embora apresentasse uma estrutura organizativa aceitável, estava voltada para a formação das elites.

Durante o Movimento da Revolução de 1930, e no período subseqüente, o Movimento da Educação consegue inserir, na Constituição de 1934, a educação como direito, nascida das inquietações políticas e democráticas. Em 1937, há um retrocesso, o que representou uma reação contra a democracia, reação que se estende por toda a ditadura Vargas, de 1937 a 1945 (TEIXEIRA AS 1968).

$\mathrm{Na}$ tentativa de salvar a educação dos ditames políticos e, até, das limitações que lhe eram impostas, o referido autor dizia que a escola pública não deveria ser investida de conotação político-partidária, mas encarado como natural postulado da sociedade democrática. 
Em 1923, a educação pública, na Bahia, contava com 630 escolas e 23.428 alunos, mas não possuía organização, nem condições de eficiência, até mesmo na capital, embora já contasse com um ginásio bem montado, vários colégios secundários particulares e três faculdades, entre as melhores do Brasil, as de Direito, Engenharia e Medicina (TEIXEIRA AS 1968).

A Constituição de 1946 reafirma a educação como um direito, de acordo com a Constituição de 1934, e a educação teoricamente passa a ser um dever do Estado, sendo fixados percentuais para educação, sobre a arrecadação de impostos assim distribuídos: $12 \%$ para a União e $20 \%$ para Estados e Municípios (TEIXEIRA AS 1968).

SAVIANI (1998), ao fazer uma análise histórica da educação brasileira, afirma que o Brasil se encontra num déficit histórico que se arrasta por 100 anos e que, para se enfrentar esse déficit, impõe-se um plano de emergência que permita investir maciçamente, com clara determinação de se assumir a educação como prioridade.

No período de 1946 a 1964, observam-se duas tendências, uma sob a bandeira do nacionalismo desenvolvimentista, e outra que defendia a iniciativa privada, se contrapondo ao monopólio estatal do ensino.

Nesse contexto, foi aprovada a primeira Lei de Diretrizes e Bases da Educação Nacional, em 1961.

Para SAVIANI (1998), até 1962, o Plano de Educação era entendido como um instrumento de racionalidade científica sob a concepção escolanovista, num período que se estende até 1985. Com o advento da Nova República, privilegia-se uma estratégia clientelista de repasse de recursos para Estados e Municípios.

Em 1993, foi editado o "Plano Decenal de Educação Para Todos", formulando estratégias para a universalização da educação fundamental e a erradicação do analfabetismo (Brasil 1993 cit. SAVIANI 1998).

A atuação do Município de Feira de Santana, na área de educação, está regulada pela Constituição Federal BRASIL (1988), que dedica os artigos 105 até 113 à Educação. Entre as responsabilidades do município, o artigo 212 da Carta Magna preceitua que os municípios deverão aplicar nunca menos que $25 \%$ da renda proveniente de impostos na Educação, e reduz essa contribuição para $15 \%$ por um período de 10 anos, por força do Artigo 60 das Disposições Transitórias. 
Com a aprovação da Lei Orgânica do Município de Feira de Santana (Lei 37/ 1990), ela incorpora, no artigo 142, o seguinte conteúdo:

“O Município aplicará, anualmente, nunca menos de trinta por cento da receita resultante de impostos, na forma disposta na Constituição Federal, e exclusivamente, na manutenção e expansão do ensino público municipal".

Este artigo evidencia a sensibilidade dos legisladores municipais ao aumentar em $5 \%$ o montante de contribuição exigida para o município. As Leis Orçamentárias referentes aos anos de 1995 a 2002, período em que há estabilização da moeda brasileira, os percentuais de aplicação, tomando-se como referência a receita total, giraram em torno de 29 a $39 \%$, em sua quase totalidade, com aplicação acima dos $30 \%$ exigidos pela Lei Orgânica do Município.

Vale ressaltar que a efetivação do Conselho Municipal de Educação se deu no ano de 2001, uma conquista recente e que é fundamental para o acompanhamento dos gastos com educação. Embora haja referência sobre a criação do Conselho Municipal de Educação em 1998, isto é contraditório em outra entrevista, o que indica que só em 2001 esse Conselho passou a funcionar com autonomia.

O Município de Feira de Santana possui 218 escolas de primeiro grau distribuídas em 100 unidades na zona urbana e 118 na zona rural, da $1^{\mathrm{a}}$ à $8^{\mathrm{a}}$ séries, com 25.381 alunos na cidade e 12.479 nos distritos. Na pré-escola ou creches conta com 8.445 alunos na zona urbana e 1.900 na zona rural. O sistema municipal mantém ainda 195 alunos especiais e na educação de jovens e adultos, 7.811 alunos na zona urbana e 1.780 na zona rural.

Os meios de acesso à educação envolvem em primeiro lugar, a disponibilidade de vagas. No entanto é colocado por um dos entrevistados:

"Nós temos no momento 222 unidades escolares no município, zona rural e urbana do município e tudo isso baseado na Lei Orgânica do município que é a Lei 1.902 de 1997”. (Ent. nº 6).

Além do número de vagas é necessário que as crianças disponham de condições básicas de alimentação e nutrição e de condições de moradia. A baixa condição sócio-econômica de parte importante da população de crianças e adolescentes é evidenciada entre aqueles que frequientam a escola pública: 
"As nossas escolas estão nos bairros periféricos, onde está toda a promiscuidade, toda a situação de pobreza". (Ent. $n^{\circ} 5$ ).

“...a família é a base de tudo, a gente sente que isso está muito fragilizado... por trás de cada problema de um jovem, de uma criança, de um adolescente está esse problema familiar, está essa falta de assistência à família”. (Ent. no 5).

O fato das escolas municipais estarem situadas nos bairros pobres é algo de bom que necessita de valorização pelo poder público. Aproveitando a localização das escolas é necessário uma ação intersetorial com as demais secretarias, especialmente com a Secretaria de Ação Social e Secretaria de Esporte e Lazer, através do qual possa complementar o trabalho da escola no turno em que as crianças e adolescentes não estejam na sala de aula e, que se busque integrar a comunidade nesse trabalho, como refere um dos entrevistados:

“A escola sozinha não faz uma educação de qualidade, é preciso que essa educação esteja inserida na comunidade e tenha uma proposta de transformação da comunidade". (Ent. 6)

A escola precisa ser incorporada à comunidade como um patrimônio seu e a família precisa assumir o dever de acompanhar o desenvolvimento da criança na escola.

A integração da escola com as associações de bairros pode se dar na forma de recreação ou lazer, mas, também, na forma de fomento a projetos comunitários de hortas e padarias comunitárias, que poderão funcionar como forma de atender algumas necessidades básicas, mas, também, como forma de ocupação e socialização.

$\mathrm{O}$ acesso à educação e o desenvolvimento pleno do cidadão, inclusive sua formação para o trabalho passa, sobretudo, pelos investimentos na qualidade do ensino.

O Fundo Nacional de Manutenção e Desenvolvimento do Ensino Fundamental (FUNDEF), se constitui numa importante fonte de financiamento da educação com repasse do Governo Federal aos municípios e recebe a seguinte referência de um dos entrevistados: 
"FUNDEF é uma verba carimbada e deve ser definida e clara para o ensino fundamental... Feira tem uma contribuição significativa..." (Ent.n $\left.{ }^{\circ} 5\right)$.

O FUNDEF pode ser visto como um instrumento da eficiência do sistema, mas ainda não é suficiente para absorver o aluno mais pobre, cujas famílias não podem prescindir do seu trabalho e, para isso, alguns municípios estão aderindo ao Programa de Renda Mínima e outros programas do governo federal voltados para públicos específicos como as crianças da região do carvão, sisal, da cana-de-açúcar (OLIVEIRA FA 1999).

Entre o ano de 1994 e 1996, há um incremento do governo federal na área social em torno de $26,8 \%$. E embora os recursos não tivessem tido uma distribuição homogênea pelos estados nem tenham sido utilizados somente em educação, trouxeram benefícios, pois os investimentos sociais têm sempre reflexos positivos na educação e na saúde, mesmo que indiretamente OLIVEIRA FA(1999).

Diante desses dispositivos legais, constata-se que o percentual orçamentário da educação para 2002 com base no orçamento total corresponde a $18.28 \%$ (de acordo com artigo 60 das Disposições Transitórias da Constituição Federal), entretanto, o percentual do orçamento proveniente da arrecadação de impostos perfaz um montante de $32 \%$, portanto, acima dos $30 \%$ exigidos pela Lei Orgânica do Município.

É interessante colocar que os índices educacionais para o município de Feira de Santana merecem investimentos mais significativos, para que possam impactar, de forma mais significativa os citados índices de qualidade da educação, que, mesmo sendo de 1991, parecem muito próximos dos atuais, de acordo com o depoimento dos formuladores e executores das políticas de educação para o município de Feira de Santana.

O Índice de Condições de Vida (ICV), para os municípios medidos pelo Programa das Nações Unidas para o desenvolvimento (PNUD); Instituto de Ciências Sociais Aplicada (IPEA); Fundação João Pinheiro (FJP) e Instituto Brasileiro de Geografia e estatística (IBGE) indica os seguintes percentuais para o ano de 1991 constantes do Quadro 8. 
Diante dos dados apresentados, constata-se uma contradição com o artigo 143 da Lei Orgânica do município sobre o direito à educação e o IDHM de Feira de Santana (Quadro 8) com uma taxa de analfabetismo que apresenta um percentual de 20,9\%. Infere-se, portanto, que o volume de investimentos na educação precisaria ser significativamente aumentado para que possa refletir, positivamente, no índice de analfabetismo do município e, ainda assim, será muito difícil o acesso universal e o preparo para o trabalho, objetivo que deve ser perseguido a médio e longo prazos, com investimentos hoje de forma séria, em quantidade e qualidade, para resgatar a grande dívida da educação referida por SAVIANI (1998).

Os dados apresentados na Quadro 8 indicam que os percentuais relacionados com o tempo de estudo e a média de anos de estudo são muito desfavoráveis, porém o que chama mais a atenção é o percentual de analfabetos, 20,9\%. Esse percentual mantém-se alto e SOUZA e CARVALHO (1999), ao analisar o analfabetismo no Brasil, registra que o país representa um dos mais altos índices da América Latina.

O referido autor afirma, ainda, que, mesmo que haja um grande investimento em educação, ainda assim nós teríamos um analfabetismo residual que, num cenário otimista, a sua eliminação no Brasil se daria por volta de 2010. Entretanto, a simples alfabetização não é suficiente para atender as necessidades mínimas de educação do indivíduo.

O problema do analfabetismo está na agenda de executores da política de educação do município de Feira de Santana, que, considerando-se as condições desfavoráveis da Região Nordeste em que se situa, deve apresentar índices mais desfavoráveis que a média brasileira:

"Estamos preparando 500 alfabetizadores, em Feira de Santana, nós ainda temos uma grande faixa de analfabetos e estamos entrando num programa de alfabetização de jovens e adultos". (Ent. $n^{\circ} 6$ )

Do ponto de vista da implantação das políticas públicas é muito importante quando a Secretaria Municipal de Educação assume a condução do ensino do primeiro grau, de acordo com exigência da Lei Orgânica do Município e, mais importante ainda, faz o acompanhamento das graves deficiências do sistema de educação. Talvez, a maior contradição seja o poder público municipal, através de seus orçamentos anuais, não apresentar uma aplicação crescente e proporcional à 
arrecadação de impostos. Por exemplo, diante da dívida social da educação, que pode ser constatada, pelos dados do ICV (Quadro 8) e pela fala dos entrevistados, percebese que, apenas com os investimentos exigidos em lei, não será possível alcançar as metas de educação para todos e de erradicação do analfabetismo estabelecidas em 1993 pelo governo federal.

Para se encontrar soluções viáveis para o analfabetismo e a evasão escolar, entende-se que há necessidade de partilhar esses problemas com a comunidade em geral e as comunidades envolvidas, em particular, para identificar as causas e solucionar os problemas referidos.

Dados de 1991, referentes ao Índice de Condições de Vida (ICV) para educação indicam altos índices de crianças fora da escola com idade entre 7 e 14 anos; defasagem na idade escolar; atraso de mais de um ano na escola e criança em situação de trabalho, englobando, nesses três últimos indicadores, crianças na faixa etária de 10 a 14 anos, conforme mostra a Quadro 9.

Retomando os dados do Quadro 9, mesmo tendo-se passado 10 anos, podem ser confirmados pelos mais recentes executores da política municipal de educação em Feira de Santana, principalmente no que se refere à defasagem escolar e ao atraso escolar, de mais de um ano, em crianças de 10 a 14 anos, o que se traduz, também, em distorção da idade em relação à série:

"Há distorção na idade em ralação à série e isso atinge quase $70 \%$ da população infantil. Nós estamos desenvolvendo dois programas para fazer essa correção”. (Ent. nº)

Diante da abordagem dos responsáveis pela execução das políticas educacionais de primeiro grau no âmbito do município, percebe-se que pouco ou nada se avançou com relação à defasagem idade e série, fato que é atribuído, em parte, ao descaso a que foi relegado o ensino na pré-escola:

“... a ênfase no País, nos últimos anos, foi dada ao ensino fundamental que vai dos 7 aos 14 anos, da $1^{\text {a à }} 8^{\text {a }}$ Série e deixou de lado a educação infantil". (Ent. $\left.n^{\circ} 6\right)$

Apesar dos graves problemas enfrentados pelo sistema de educação fundamental do município, executores das políticas municipais admitem, de forma otimista, o alcance da universalização do ensino, ainda que a qualidade seja deficiente. 


\begin{abstract}
“a nossa criança estuda apenas 4 horas por dia ... ...já alcançamos praticamente a universalização do ensino fundamental, nós precisamos pensar seriamente, pensar na qualidade da educação". Ent. $\left.n^{\circ} 6\right)$.
\end{abstract}

Enquanto os brasileiros permanecem em média 7 anos na escola, a Coréia do Sul quer garantir um mínimo de 18 anos de estudo para toda a força de trabalho, sem citar o primeiro mundo onde a supremacia não é apenas quantitativa, pois os seus cidadãos têm uma educação de qualidade superior à brasileira. Se o Brasil investir em qualidade e conseguir melhorar os indicadores de educação, poderá elevar o patamar de período de estudo para 9 anos (PASTORE 2002).

Por outro lado, sabe-se que os problemas da educação não têm suas causas localizadas apenas no sistema educacional, mas extrapolam a escola, embora se reflitam nos indicadores da educação e, vale lembrar, que a dimensão do desenvolvimento de um país é medido pelo desenvolvimento dos seus recursos humanos (DEMO 1988) e que os investimentos em educação não geram efeitos imediatos, mas são refletidos nas gerações seguintes.

A educação como liberdade substantiva reforça as liberdades instrumentais, políticas, facilidades econômicas e oportunidades sociais para o desenvolvimento das potencialidades humanas (SEN 2002), coerente com o preceito do artigo 134 da Lei Orgânica que coloca como objetivo da educação o pleno desenvolvimento do cidadão, tornando-o capaz de refletir criticamente a realidade e ser preparado para o trabalho.

OLIVEIRA JB (2001), faz referência ao papel do investimento público em educação ao analisar o trabalho de Glumm e Ravikumar (1992), que indica dois mecanismos que ligam uma geração a outra: - o estoque do capital humano dos pais que afeta o aprendizado dos filhos; e a ligação através da herança, ou seja, a qualidade da educação recebida pelos filhos, que não difere entre famílias da mesma geração, no sistema de educação pública, o que coaduna com o entendimento de um dos entrevistados:

"Eu sempre digo que o maior desafio aqui da rede é alfabetizar filhos de analfabetos... ... porque a família só pode valorizar o 
estudo, se ela sabe o significado e a função social do conhecimento". (Ent.n $\left.{ }^{\circ} 5\right)$.

Essa fala remete à preocupação da escolarização dos membros das famílias e da comunidade que, por estarem envolvidas no ciclo vicioso, faz-se cada vez mais, necessário, se pensar em formas de se romper com esta situação, o que faz emergirem alguns questionamentos:

- será que é necessário pressionar os pais a manter seus filhos na escola?

será conveniente oferecer ajuda financeira à família sob a condição de manter os filhos na escola?

- será que as escolas terão que encontrar novos atrativos para manter a criança na escola?

- será que os docentes não precisam ter suas condições de trabalho mais atrativas?

- será que um mutirão intersetorial poderá num trabalho integrado buscar as causas dos problemas que afetam o sistema educacional?

- será que a mídia, com seu grande potencial de formador de opinião, pode ajudar na solução dos problemas da educação?

Para se pensar em solução para os problemas da educação no Brasil, sabe-se que é necessário um elevado grau de investimento do governo, aliado ao envolvimento da comunidade em geral.

O crescimento experimentado pelo Brasil, na década de setenta, o chamado "milagre econômico", além de não ter reflexos proporcionais na vida dos brasileiros, provocou mais endividamento e mais sacrifícios, aumentando, mais ainda, a dívida social do País.

Só em 1995, tem início, no Brasil, a redefinição do papel do governo federal na estruturação federativa brasileira e, particularmente, no sistema educacional do país (OLIVEIRA FA 1999).

$\mathrm{O}$ autor refere que, embora o montante dos recursos federais destinados à área social tenha sido da ordem de 26,8 \% do orçamento, no período de 1994 a 1996, o percentual de recursos destinados à educação foi 17,3 \% negativos. As dotações previstas pela Lei do FUNDEF começaram a ser liberadas em 1998 e a Lei que regulamenta a bolsa escola começou a ser liberada no ano de 2001. 
Os investimentos sociais realizados no Brasil entre 1994 e 1998 estavam previstos desde a Constituição de 1988, considerada uma das constituições mais avançadas do mundo o que the deu o título largamente divulgado de "Constituição Cidadã". Entretanto, o Brasil permaneceu paralisado nos seus investimento em educação e renda, pela instabilidade econômica que se instalou no país por muitos anos e pela falta de capacidade dos políticos de negociar e priorizar investimentos para as reais necessidades do país, com vistas a construir um futuro melhor.

Em 1980, $80 \%$ das crianças em idade de estudar estavam matriculadas, havia 4 milhões de crianças fora da escola. No ano de 1999, de acordo com dados do IBGE 95,7 \% estavam na escola, o que sem dúvida, significa um avanço, mas, se comparado aos Estados Unidos, vê-se que existe um enorme abismo: Em 1850, quando $90 \%$ dos brasileiros eram analfabetos, apenas $10 \%$ dos americanos estavam nessa situação.

De acordo com dados da UNESCO, em 1994 cit. SOUZA e CARVALHO (1999), as taxas de analfabetismo no Brasil (18\%) são altas se comparadas com outros países da América Latina, como Argentina (4\%), Chile (6\%) e Paraguai (10\%).

No sentido de recuperar os investimentos na área de educação, o processo de descentralização da administração do sistema educacional no país tomou forma com as modificações ocorridas no Programa de Manutenção e Desenvolvimento do Ensino Fundamental (PMDE), com o Programa de Apoio Tecnológico (PAT) e com o Programa Nacional de Alimentação Escolar.

Para ALMEIDA ES (1995), citado por OLIVEIRA FA (1999), o processo de descentralização assumiu formas variadas para cada Estado:

- a municipalização que se caracteriza pela transferência de competências, atribuições, instalações e equipamentos dos Estados para os Municípios com garantia de autonomia;

- a desconcentração, que representa a delegação limitada de atribuições no mesmo nível para unidades regionais e locais.

Assim, pode-se afirmar que a relação do Governo do Estado da Bahia com o Município de Feira de Santana estaria enquadrado no segundo tipo de descentralização, como se constata na fala de um dos entrevistados: 
"O município, por conta de ainda não ter o sistema municipal de educação"... ...você sabe que interfere muito as políticas partidárias. Quando acontece a política partidária ser a mesma, não é ? No Estado e no Município"... ...."o sistema municipal está atrelado, está sob a tutela do sistema estadual de educação". (Ent. $\left.n^{\circ} 5\right)$.

Esses são mais alguns obstáculos que se colocam frente aos inúmeros problemas na área da educação no município em foco. Mesmo que esses obstáculos sejam removidos de uma gestão municipal para outra, são sempre problemas recorrentes, pelas disputas de poder, mas que têm conseqüências graves a médio e longo prazo, no perfil da educação no Município.

O processo de descentralização da educação não se dá de forma homogênea e os programas do Ministério da Educação e Cultura (MEC) vão sendo, cada vez, mais absorvidos pelo município, no mínimo como forma de captação de recursos financeiros:

"Nós temos parceria com todos os programas do MEC ... a merenda escolar, que é um dos programas sedimentados e que no município acontece muito bem"... ..."hoje os livros já estão numa linha melhor, o próprio MEC já faz uma grande seleção lá e ele chega para nós". (Ent. N 5 ).

"Nós temos o programa da TV escola, que toda a informação também chega para nós ... ... Nós temos o programa do Pró-Info. Só no Colégio Municipal, tem 37 computadores, coloca também o nosso aluno em contato não mais com o Brasil, mas com o mundo".(Ent. No 5).

"Projeto voltado para a qualidade dos nossos docentes, a formação continuada dos professores..." "...estamos com três projetos nesse sentido em parceria com o Ministério da Educação"... ..."Programa tempo de lutar, estimulando nossas escolas à leitura por parte do aluno"... ...“'O projeto de Educação especial também será referência na Secretaria de Educação de Feira de Santana...” “...fomos um dos primeiros municípios que aderiu ao programa bolsa-escola, espera- 
se com esse programa, diminuir os índices de evasão e repetência, contribuindo também, por outro lado para melhoria da educação". (Ent. $\left.\mathrm{n}^{\circ} 6\right)$.

No bojo do processo de descentralização e do incremento dos investimentos constatado na fala de todos os entrevistados na área de educação e referido por OLIVEIRA (1999), no ano de 1996 resgatam-se realizações importantes, como a aprovação da Lei de Diretrizes e Bases da Educação Nacional (LDB), a aprovação da Emenda Constitucional n. 14, que estabelece a criação dos fundos estaduais de Manutenção e Desenvolvimento do Ensino Fundamental e de Valorização do Magistério (FUNDEF), e da Lei n. 9.424, que regulamenta esse fundo, desencadeando importantes avanços na organização e no financiamento do sistema de ensino no Brasil.

Foi instalado o Programa de Apoio aos Secretários Municipais de Educação (PRASEM), em 1997, como uma iniciativa do MEC (Ministério da Educação e Cultura), UNICEF (Fundo Internacional para o Desenvolvimento da Criança) e Banco Mundial com o objetivo de elevar a competência técnico administrativa dos secretários municipais de educação como suporte ao ensino fundamental (MEC 1999).

Pode-se perceber o esforço no sentido de reverter as enormes carências na área da educação, mas, os investimentos necessitam de regularidade a longo prazo e entendese que isso só se consolida no tempo quando a sociedade assume essa concretização.

A participação social, um direito de cidadania conquistado no século $\mathrm{XX}$ representa a conquista do estado de direito (ANDRADE 1993) e implica que as relações sociais de direito serão garantida pelo Estado (ODONNEL in ANDRADE 1993).

Certamente, o caminho mais seguro da participação social se dá através dos Conselhos, em cuja composição podem ocorrer dificuldades iniciais, em sua composição, sendo esta a oportunidade de acompanhar as aplicações financeiras dos programas e a avaliação dos resultados.

De acordo com os entrevistados na área da educação, os conselhos já estão em funcionamento: 
“A educação está toda ela administrada por conselhos. Em primeiro lugar, nós temos o nosso conselho maior, que é o Conselho Municipal de Educação a quem compete definir a política de educação do município... dá autonomia plena ao sistema de educação"... ... "O Conselho Municipal de Educação foi implantado em 1998. Quem compõe esse conselho são vários segmentos da sociedade, eleitos por assembléia" (Ent. n ${ }^{\circ}$ 6).

"Conselhos tutelares... eles entraram na escola com palestras e eles saíram para dar assistência às famílias desses jovens drogados, mostrando como trabalhar, enfim, como vencer o problema".(Ent. $\left.\mathrm{n}^{\circ} 5\right)$.

"Temos o conselho do FUNDEF que fiscaliza a aplicação de recursos para a educação; temos o conselho da merenda escolar; o programa bolsa-escola, ele é também acompanhado, fiscalizado e supervisionado por um conselho, paritário; a própria unidade escolar é gerida por um conselho que é o conselho da escola que nós chamamos unidade executora da escola" (Ent. n 6).

Por mais que pareçam lentos os investimentos em educação, percebe-se que a década de 1990 traz como herança importante da década de 1980, o processo de democratização do país, que culmina com a aprovação da Constituição de 1988, pródiga em benefícios sociais. pode-se dizer que representou o sonho de um Estado de Bem Estar Social do Brasil. Entretanto esse modelo não se operacionaliza apenas na letra da Carta Magna, mas com vontade política dos governantes, com a pressão da sociedade civil organizada e com a priorização e alocação de recursos em áreas sociais.

Mesmo com a defasagem de tempo, é preciso que se assuma a questão relacionada à educação como um dever do Estado, que terá o seu desenvolvimento condicionado ao desenvolvimento dos recursos humanos existentes no País.

É necessário, também, que o direito da população à educação seja revestido de uma cidadania ativa e complemente o dever da sociedade de efetivar e consolidar esse direito básico de cidadania. 
Entende-se que, só dessa forma, é possível efetivar o preceito da Lei Orgânica do Município de Feira de Santana no Artigo 134, que tem como base o artigo 205 da Constituição Federal:

"A educação é um direito de todos, dever do poder público e da sociedade, tem como objetivo o pleno desenvolvimento do cidadão, tornando-o capaz de refletir criticamente sobre a realidade e ser qualificado para o trabalho".

\subsection{Política de Saúde para o Município de Feira de Santana}

Das experiências de descentralização de políticas públicas analisadas por Almeida (s.d.), citado por OLIVEIRA FA(1999), a saúde é a única que foi contemplada com uma política nacional. Embora considere que o Sistema Único de Saúde esteja longe de estar totalmente constituído, não hesita em afirmar que nessa área, o processo de descentralização teria promovido uma verdadeira revolução.

A Constituição de 1988 incorpora conceitos, princípios e uma nova lógica de organização da saúde de acordo com a reforma sanitária: conceito de saúde entendido numa perspectiva de articulação de políticas econômicas e sociais; a saúde como direito social universal deriva do exercício de cidadania plena e não mais como um direito previdenciário; a caracterização dos serviços e ações de saúde como de relevância pública; a integração da saúde a Seguridade Social (BRASIL 1988).

A criação do SUS significa a instituição de um sistema único de saúde, baseado nos princípios doutrinários de universalidade, equidade, integralidade e participação social.

$\mathrm{Na}$ constituição desses princípios estão definidos da seguinte forma:

- Universalidade - todas as pessoas tem direito à saúde. Saúde como direito de cidadania e dever do Estado.

- Equidade - os serviços de saúde devem considerar as diferenças dos vários grupos da população e trabalhar para atender a cada necessidade, oferecendo mais a quem precisa mais, diminuindo as desigualdades existentes.

- Integralidade - as ações de saúde devem ser combinadas e voltadas, ao mesmo tempo, para a promoção da saúde, prevenção específica, cura e reabilitação. 
- Participação social - através dos conselhos de saúde, com representação paritária de usuários, governo, profissionais de saúde e prestadores de serviços com poder deliberativo (BRASIL 1988).

Na década de 1990, a ordem, no campo das políticas sociais, passa a ser a fragilização do papel do Estado, a diminuição do seu papel redistributivo, a privatização e a focalização das políticas para grupos populacionais carentes e excluídos.

Nesse período, prevaleceu, na área de saúde, o privilegiamento do setor privado, com forte apelo ideológico, sustentado por uma política deliberada de desmonte do setor público (CHIORO E SCAFF 1997). Entretanto, continuou a luta pela implantação do SUS, o que é regulado pelas Leis 8080 e Lei 8142 de dezembro de 1990, classificadas como Leis Orgânicas da Saúde.

Em 1991, passaram a vigorar as Normas Operacionais Básicas - instrumento jurídico editado periodicamente, após amplo processo de discussão para orientar a implementação do SUS. As Normas Operacionais Básicas - NOB 91 e NOB 92 foram editadas através de Resolução do INAMPS e NOB-SUS-93, através de resolução do SUS, depois da reforma ministerial e extinção do INAMPS. Após intensa mobilização, mais de 100 municípios passaram à gestão semi-plena de acordo com a NOB-93, englobando entre 10 e $12 \%$ da população brasileira e $18 \%$ dos recursos gastos com assistência.

Em 1996, com a edição da NOB-SUS-96, foi reforçado o processo de descentralização via municipalização, com a perspectiva de repasse de recursos fundo a fundo, sendo estabelecidas as duas condições de gestão para os Municípios: Gestão da Atenção Básica e Gestão Plena do Sistema Municipal. Para os Estados: Gestão Avançada do Sistema Estadual e Gestão Plena do Sistema Estadual (ALMEIDA 1995; BRASIL 1997).

De acordo com CHIORO (1997), a dinâmica das políticas de saúde, ao longo da década 1980/1990, permitiu crescente grau de universalização, embora de forma excludente, discriminatória, com distribuição seletiva de serviços de saúde a partir de mecanismos racionalizadores para diferentes cidadanias e fixada na atenção médica.

$\mathrm{Na}$ Bahia, o processo de descentralização da saúde avança na década de $80 \mathrm{com}$ a implantação das Ações Integradas de Saúde (AIS), até a implantação do SUDS. 
Com o declínio do financiamento público para a área de saúde, que, em 1987 chegou a receber $37 \%$ do Fundo da Previdência, e em 1993, não recebeu nenhum recurso (NORONHA e LEWCOVITZ 1994) e com o retrocesso político de transição do governo, cujos efeitos se produziram no MPAS, especialmente pela demissão do presidente do INAMPS, as AIS/SUDS esgotam-se como estratégia, mantendo-se como programas com seus resultados racionalizadores pouco visíveis (PAIM 1988).

TEIXEIRA CF (1991), em seu artigo intitulado "Municipalização da Saúde: os Caminhos do Labirinto", afirma que a conjuntura observada entre 1986/1989 não avança no sentido de fortalecer os esforços no plano jurídico-parlamentar e que, no campo da saúde, prevalece a vitória da ideologia neoliberal, gerando duas implicações: a desresponsabilização progressiva do Estado sobre as políticas sociais e da saúde em particular e a privatização dos setores mais rentáveis da assistência ambulatorial e hospitalar.

De acordo com dados do CONASEMS, em 1999, o Estado da Bahia figura como um dos mais atrasados no processo de implantação do SUS. Dos 415 municípios, apenas 10 encontrava-se na condição de gestão plena do sistema municipal e 395 na condição de gestão plena da atenção básica.

O presidente do CONASEMS - BA (CORDEIRO s.d.), critica a forma como os governos que se sucederam após a promulgação da Constituição de 1988, em que estão estabelecidos os princípios para implantação do SUS, se omitiram, influenciando para que isto, de fato, ocorresse. Esses governos procuraram dificultar ou adiar a implantação do SUS, principalmente, através da não definição das fontes de financiamento para a saúde.

Entretanto, se evidencia que o período de 1998 e 1999 está entre aqueles em que houve crescimento da habilitação dos municípios nas formas de gestão previstas na NOB/96, apesar das graves dificuldades econômicas e sociais. Entre essas dificuldades econômicas, o representante do Conselho Nacional de Secretários Municipais de Saúde - Bahia (CONASEMES - BA), reafirma a indefinição das fontes de financiamento e a resistência ao processo de descentralização por parte do Ministério da Saúde e do gestor estadual (CORDEIRO s.d.).

Em consonância com o texto constitucional de 1988, a Lei Orgânica do município de Feira de Santana - 1990, no artigo 158 diz: "O município integra com a União e o 
Estado o Sistema Único de Saúde, cujas ações e serviços públicos, na sua circunscrição territorial serão por eles dirigida".

Esse preceito da Lei Orgânica, está baseado nos artigos 196 a 200 (BRASIL 1988) define o processo de municipalização como estratégia de descentralização da saúde, o que é regulamentado pela Lei Orgânica da Saúde - Leis 8080 e 8142 de 1990.

Entretanto, o arcabouço legal não garante a implementação de ações que segundo THOMPSON (1981), depende do comportamento e da rotina administrativa, da cultura política e dos interesses dos grupos contrários a essa implementação.

O processo de municipalização da saúde em Feira de Santana, que tem como referência as políticas de saúde nacional e regional conforme foi referido por diversos estudiosos (FONTES TEIXEIRA CF 1991; PAIM 88; FLEURY 1994; MENDES 1993 e LUZ 1994), encontrava-se apenas no plano das intenções. De acordo com ASSIS (1998), o projeto de reforma sanitária enfrenta obstáculos vinculados ao caráter patrimonial e privatizado do estado brasileiro, aliado à expansão da ideologia neoliberal na administração pública, à desmobilização da sociedade civil e ao modelo assistencial centrado na doença.

No Município de Feira de Santana, reproduz-se o atraso no processo de municipalização da saúde, sem que se registre nenhum movimento organizado de cunho local para efetivação do SUS. A Universidade Estadual de Feira de Santana, como exceção tem buscado, através da formação de recursos humanos, fortalecer os quadros das secretarias estadual e municipal de saúde, especialmente no âmbito de pós-graduação, especialização e mestrado, embora se considere as diferentes lógicas da academia, como lócus de discussão das idéias e dos serviços que representam a prática propriamente dita.

Entretanto, apenas o esforço da instituição formadora não é o suficiente para efetivar uma política de saúde para o município, se não for assumida sua operacionalização pelo órgão gestor da saúde municipal, que é a Secretaria Municipal de Saúde. Em alguns momentos há gestores que assumem as responsabilidades inerentes à implementação do SUS:

"Feira de Santana, a partir do momento que pactuou assumir as responsabilidades das ações básicas, ela teve que ampliar o seu 
universo de procedimentos até para que ela pudesse atender à pactuação"... (Ent. no 8$)$.

Talvez um dos fatores que concorram para fragilizar as reformas no sistema de saúde de Feira de Santana, com vistas à efetivação do Sistema Único de Saúde seja a freqüente mudança dos condutores desse sistema. Por exemplo, do segundo semestre do ano de 1999 quando esse projeto de pesquisa começou a ser montado até o primeiro semestre de 2002, o município teve quatro diferentes secretários de saúde.

Para assumir a responsabilidade das ações básicas de saúde, a NOB-SUS 01-96 prevê a organização da rede básica de serviços, inclusive domiciliar e comunitária e a implantação de serviço de referência ambulatorial, especializada e hospitalar.

$\mathrm{O}$ gestor reconhece a importância do repasse do Piso de atenção Básica (PAB), como importante fonte de receita:

"Nós recebemos hoje em torno de 500 mil reais de verba a título de $\mathrm{PAB}$, são recursos significativos que bem gerenciados eu não tenho dúvidas que traga respostas a médio e longo prazos". (Ent. $\mathrm{n}^{\circ} 8$ ).

Entretanto, contraditoriamente, parece que mantém suas ações centradas em programas estanques com base de avaliação apenas na produtividade, mesmo reconhecendo que esse enfoque não é resolutivo dos problemas. E, também, não apresentam propostas de mudanças estruturais do atual modelo assistencial:

"Quantitativamente os procedimentos da secretaria aumentaram $116 \%$..... aumentar a produtividade não resolve a situação por si ... precisamos melhorar a resolutividade, é aí que entra a transformação do atendimento prestado pelas unidades de saúde"(Ent. no 8$)$.

A vivência, na área de saúde, permite inferir que o processo de municipalização em Feira de Santana vem se impondo enquanto uma política irreversível do Ministério da Saúde. Porém, no nível local, se ressente da ausência de estruturação de um sistema regionalizado de saúde, no sentido de atendimento à demanda organizada, com base nas necessidades da população, condizente com as diretrizes do Sistema Único de Saúde, mesmo com as limitações inerentes à condição de gestão plena da atenção básica (NOB/SUS - 0196). Ainda que executores da política de saúde do município tenham tentado avançar: 
"Eu diria que a Prefeitura de Feira de Santana, ou melhor, eu diria que o Estado da Bahia é um, nos últimos anos, eu diria que está caminhando o tempo perdido e avançando, definitivamente, em direção à municipalização da saúde". (Ent. $n^{\circ} 8$ ).

Fazendo-se uma comparação dos investimentos realizados em saúde, nos últimos anos em Feira de Santana, percebe-se que o processo de municipalização da saúde teve menos investimentos na década passada. A Figura 7, apresenta os valores investidos, de acordo com o orçamento entre os anos de 1993 e 2002.

Da aplicação de $11,3 \%$ do orçamento na área da saúde, cai para 7,80\% e volta a crescer até 12,20\% em 1996 e, embora haja aumento na aplicação orçamentária global para 1997, o orçamento da saúde para o mesmo ano cai para $11,77 \%$, tornando-se portanto menor que no ano anterior. Continua a cair em 1998, tanto o valor total do orçamento como o percentual de aplicação para a saúde que passa para 10,83\%. Em 1999 o percentual de dotação orçamentária volta a subir atingindo $34,2 \%$ em 2002, a maior dotação, ultrapassando a dotação orçamentária da educação, que historicamente vinha se configurando como a rubrica que detém o maior percentual de dotação do orçamento municipal.

Por outro lado, formuladores e executores da política de saúde do município não demonstram controle sobre as destinações orçamentárias para a saúde:

"Não existe, no orçamento de Feira de Santana, um percentual determinado sob a receita do município que lhe destina obrigatoriamente à saúde. É isso que queremos avançar, inclusive agora, na Conferência Municipal de Saúde, que nós vamos realizar". Ent. $\mathrm{n}^{\circ} 8$ )

Do ano de 1998 a 2001, há um crescimento percentual tanto no valor de aplicação do orçamento total como no orçamento destinado à saúde, o que se supõe estar relacionado ao repasse do Piso de Atenção Básica (PAB).

A previsão orçamentária para a saúde entre 2001 e 2002 apresenta significativa elevação, passando de $\mathrm{R} \$ 20.821 .000,00$ (vinte milhões, oitocentos e vinte e um mil reais) para $\mathrm{R} \$ 62.840 .412,00$ (sessenta e dois milhões, oitocentos e quarenta milhões quatrocentos e vinte reais) o que representa um aumento percentual da ordem de $34,2 \%$ 
O aumento da aplicação orçamentária na saúde, no período de 2001 a 2002, ocorre em função do processo de municipalização com a proposta de mudança da condição de "gestão plena da atenção básica" para a "gestão plena do sistema municipal" (NOB / SUS - 01 / 96). A diferença orçamentária corresponde ao repasse da seguridade social que deverá integrar o orçamento da saúde para o município, o que, porém, não havia sido concretizado até junho de 2002.

Mesmo que o município esteja pleiteando a, até o presente momento (novembro de 2002) não conseguiu efetivar na prática a "gestão plena do sistema municipal". Até mesmo porque a concepção das ações da Secretaria de Saúde parecem centradas na produtividade, sem apresentar resolutividade de problemas, tomando-se como base algumas falas dos entrevistados:

"Nós estamos hoje com não menos que 20 programas de saúde... ...Queria destacar 4 programas: o programa de Agentes Comunitários de Saúde (PACS); o Programa de Combate ao Aedis Aegypti, Combate à Dengue; o Programa de Combate à Leshmaniose e o Programa de Combate a Roedores". Ent. n 8).

"Nós já encontramos o plano mais ou menos delimitado para o ano 2000 e 2001, trabalhamos em cima daquele plano e, para 2002, nós já fizemos oficinas para que a gente possa aperfeiçoar tudo aquilo que foi feito em 2001 "...

“...São vários programas, temos PAISC, que é um programa de atenção integral à criança; o PAISM que é um programa de atenção integral à saúde da mulher; nós temos o programa de diabetes e hipertensão. Então, são vários programas, inúmeras ações no sentido de melhorar a saúde da população"...

“...Naquilo que há de mais novo e de mais preciso em saúde, todos nós temos conhecimento é o Programa de Saúde da Família... ...Nós colocamos em funcionamento 21 equipes praticamente já trabalhando, oficialmente montamos 2 equipes e os resultados já são altamente satisfatórios". (Ent. $n^{\circ} 9$ )

Observa-se, nas falas dos entrevistados, que o sistema de saúde ainda é sentido como fragmentado, não sendo feitas referências aos problemas nem às metas ou 
objetivos que se pretendem alcançar. Percebe-se que a temática da municipalização da saúde é colocada como um fím que se operacionaliza em função dos programas implementados, inclusive como se os programas pudessem melhorar os indicadores sociais. Um exemplo é a não explicitação de como são medidos esses indicadores.

É possível que os entrevistados reflitam um comportamento organizacional ainda pontual da organização pública, sem estabelecer interfaces entre os campos de intervenção na área social.

\subsection{Política de Meio Ambiente para Feira de Santana}

Inquestionavelmente, há uma relação direta entre meio ambiente e qualidade de vida, não só do ponto de vista dos recursos naturais do meio ambiente, tais como disponibilidade de mananciais de água, solo propício à vegetação, clima, chuvas, mas também em relação aos recursos artificiais, necessários à manutenção de condições aceitáveis de qualidade de vida, como saneamento básico (tratamento de água e esgotos ou destinação adequada dos resíduos), uso e ocupação adequada do solo e outros recursos da natureza.

O meio ambiente natural, através dos rios e lagoas, pode necessitar de cuidados especiais para evitar a proliferação dos vetores de doenças, ao mesmo tempo em que, devem ser desenvolvidas ações educativas e de prevenção específica para conservação dos recursos naturais.

Em 1992, ocorreu a Conferência das Nações Unidas sobre Meio Ambiente e Desenvolvimento no Rio de Janeiro, Brasil, cujo documento oficial, a chamada Agenda 21, foi assinada por representantes de 179 países e se tornou um extenso diagnóstico das desigualdades sociais e econômicas no mundo inteiro.

Nessa Conferência, foi apresentada uma clara mensagem aos políticos e representantes internacionais sobre a necessidade de um melhor ambiente e desenvolvimento sustentável para alcançar a equidade.

Em 1999, a OPAS/OMS publicou, no Brasil, um extenso documento intitulado "Atenção Primária Ambiental", seguindo os princípios da Declaração de Alma-Ata, em 1978, com o objetivo de alcançar as melhores condições de saúde e qualidade de 
vida, através da proteção do ambiente e do fortalecimento das comunidades, no âmbito da sustentabilidade local.

Para que isso seja alcançado, a OMS propõe como objetivos específicos:

- contribuir para a construção de municípios saudáveis;

- fortalecer a capacidade de gestão ambiental;

- facilitar a fim de que haja uma maior interação entre setor público e sociedade civil para o estabelecimento de compromissos e prioridade do desenvolvimento sustentável local.

A Organização Mundial da Saúde (OMS), Organização Pan-americana de Saúde (OPAS) o Fundo das Nações Unidas para a Infância (UNICEF) e os governos, têm assumido compromissos e responsabilidades para orientar suas ações através de diversos eventos realizados, como a Conferência das Nações Unidas sobre Meio Ambiente e o Desenvolvimento (ECO-92, Rio de Janeiro, 1992), a Conferência das Nações Unidas e Desenvolvimento Sustentável dos Pequenos Países Insulares em Desenvolvimento (SIDS), Barbados (1994), a Conferência de Cúpula das Américas (Miami 1994); a Conferência Pan-americana sobre Saúde e Ambiente no Desenvolvimento Humano Sustentável (Washington, D.C. 1995) e as Reuniões de Cúpula de Santa Cruz de la Sierra (Bolívia, 1996) e Santiago (Chile 1998).

Nesses eventos, se evidencia que a conservação e proteção da saúde e do ambiente são o centro da preocupação do novo modelo de desenvolvimento, com ênfase especial na dimensão humana, quer dizer, no desenvolvimento centrado na população.

Da declaração do ECO-92, ressalta-se como princípio:

"Os seres humanos constituem o centro das preocupações do desenvolvimento sustentável. Por conseguinte, tem o direito a uma vida saudável e produtiva em harmonia com o ambiente natural... ...preservação do meio ambiente reflete em melhoria para a saúde" (OMS 1992).

Da carta Pan-Americana sobre saúde e Ambiente no Desenvolvimento Humano Sustentável, divulgada em 1995 em Washington, ressalta-se:

“a participação comunitária deve basear-se em estratégias para o desenvolvimento sustentável, incluindo a atenção primária do meio 
ambiente, a atenção primária da saúde e a educação das crianças e adultos".

Da $25^{\text {a }}$ Conferência Sanitária Pan-Americana em 1998, na cidade de Washington ressalta-se a aprovação das orientações estratégicas e programáticas (OEP), dirigidas ao alcance da meta mundial de saúde para todos no século XXI.

De acordo com OMS/OPAS (1995) apenas $72 \%$ da população têm ligação de água nos seus domicílios ou a uma distância inferior a 200 metros. Um problema grave, em todos os países da América Latina e no Caribe, é a descarga de águas residuárias, sem tratamento, em que menos de $10 \%$ recebem algum tratamento e, às vezes, inadequado. Como dificuldades foram identificadas as cinco maiores: falta de uma política adequada para o setor; limitação de recursos financeiros; arranjos institucionais inadequados; falta de um sistema adequado de recuperação de custos; e a obsoleta legislação existente.

A Constituição brasileira vigente no Artigo 23, Incisos VI e VII estabelece como responsabilidade da União, Estados, Distrito Federal e Municípios, a proteção do meio ambiente e o combate à poluição em qualquer de suas formas e a preservação da fauna e da flora (BRASIL 1988).

O Município de Feira de Santana incorpora tais preceitos na Lei Orgânica em 1990 e avança ainda no campo legislativo com a aprovação da Lei Complementar $N^{\circ}$ 1.612/1992 - Feira de Santana, que dispõe sobre o Código do Meio Ambiente.

O município sofre de problemas semelhantes aos descritos pela Organização Panamericana de Saúde para a América Latina, principalmente porque o seu potencial hídrico, largamente estudado por setores específicos da Universidade Estadual de Feira de Santana a exemplo do "Projeto Nascentes - Um olhar sobre Feira de Santana”, não tem recebido das autoridades locais e da população a devida atenção para que essa mesma população possa gozar de melhores condições ambientais e legar às próximas gerações um ambiente mais adequado para viver.

Ao abordar as questões relacionadas à degradação do meio ambiente, não se pode perder de vista a história de Feira de Santana que nasce no século XVII, após a formação de um povoado por se constituir um pouso adequado para os homens e o gado pela abundância da água aí existente. 
O município de Feira de Santana apresenta períodos de seca, fenômeno característico das regiões semi-áridas, intercalados por período úmido, quando a evaporação é menos significativa. Entretanto, o regime hidrológico da região controla a dinâmica hídrica das lagoas (FRANCA ROCHA e NOLASCO 1995).

As questões relacionadas com o meio ambiente são discutidas em nível internacional e são, cada vez mais, assumidas como problema de todas as Nações, e devendo ser resolvidas de forma coletiva. Entretanto, no nível local, os problemas ambientais vão sendo transferidos de uma administração para outra, sem o devido acompanhamento da comunidade. Coloca-se a seguir a fala de um dos secretários municipais entrevistados:

"Infelizmente, quando esse governo assumiu, a maioria das lagoas já tinha uma ocupação desordenada"...

..."A Lagoa Grande é um dos minadouros do Rio Pojuca. Está totalmente contaminada pelos esgotos daquela redondeza, cabe à EMBASA, através do Estado, providenciar o esgotamento sanitário".(Ent. $\left.\mathrm{n}^{\circ} 11\right)$

De acordo com dados das entrevistas, percebe-se que, além das condições precárias dos recursos naturais do município e a crescente degradação do ambiente, indica-se o Governo do Estado como responsável pelas obras de esgotamento sanitário, alegando-se ainda problemas políticos na realização de tais serviços:

"cabe ao Estado, através da EMBASA, providenciar o esgotamento sanitário, mas por uma questão ainda política. E ainda nesta política (período eleitoral) eles estão anunciando que vão fazer mas já deveriam ter feito...”(Ent. $\left.n^{\circ} 11\right)$.

No sentido de oferecer uma maior aproximação à realidade do potencial hídrico de Feira de Santana, será apresentada uma figura com destaque das lagoas. 
Figura 8 Mapa de localização das Lagoas de Feira de Santana em relação às principais ruas.

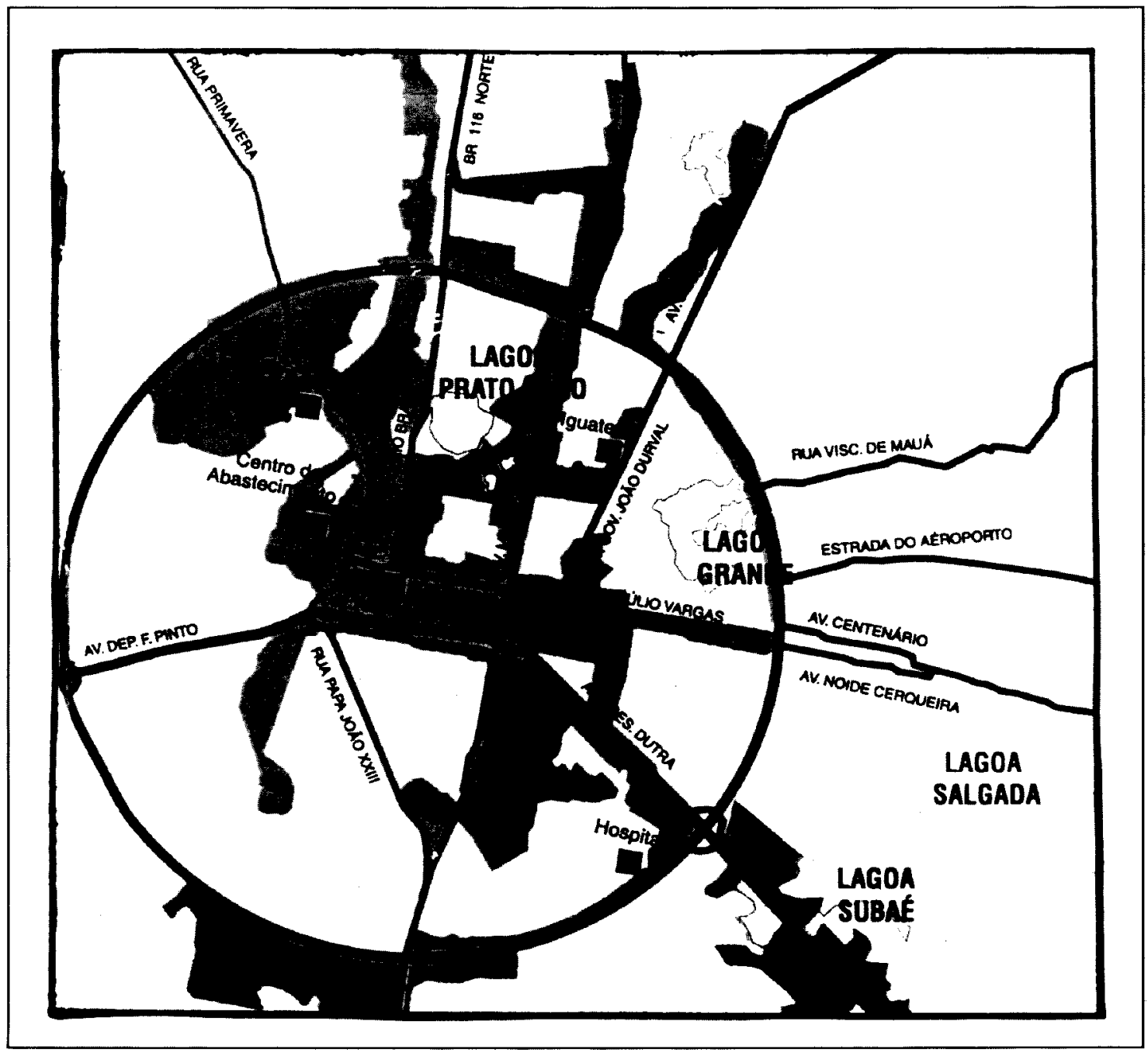

Fonte: Agenda 21 de Feira de Santana / Sec. De Meio Ambiente

Os problemas decorrentes da deficiência no saneamento básico afetam a vida de milhões de pessoas no mundo inteiro. Em 1991, a epidemia de cólera que apresentou 1,3 milhão de casos com mais de 11.500 casos fatais. Na América Latina, incluindo o 
Brasil, a diarréia é responsável pela morte de 80.000 crianças anualmente (OMS/OPAS 1999).

A contaminação dos mananciais hídricos de Feira de Santana prejudica a saúde de sua população e de cidades num raio de mais de 100 quilômetros.

Esta realidade servirá de argumento para que a administração municipal possa obter verbas federais ou estaduais para enfrentar os problemas de saneamento básico do município:

"Lagoa Grande, hoje, é um sanitário a céu aberto, uma fossa a céu aberto, todo esgotamento dessas casas, esgoto sanitário, tudo vai ali para dentro. Então, ele vai poluir lá em baixo, lá na Praia do Forte, em Salvador”. “A intenção é essa, tratar aquela região toda e nessas outras áreas. No orçamento, está contemplando muito, a parte de educação e esgotamento". (Ent. n 4 ).

Os dados de ICV sobre habitação apresentam vários indicadores sobre as condições de vida de uma parte da população de Feira de Santana, que indicam o nível de pobreza e a degradação do meio ambiente que prejudica a população mais carente e a população que possui melhor poder aquisitivo através da contaminação dos mananciais e locais de lazer como rios e o mar.

Esses dados de ICV sobre habitação podem ser observados no Quadro 11 referente ao ano de 1991 e vem se agravando nos últimos anos.

De acordo com dados do ICV (Quadro 11), está havendo diminuição na cobertura de esgotamento sanitário para o município, da década de $80(48,2 \%)$ para a década de $90(45,9 \%)$ e uma década depois; de acordo com dados da entrevista realizada no ano de 2002, há uma defasagem ainda maior, em torno de 30 a $40 \%$ de cobertura, com a perspectiva reverter esse quadro e de alcançar 80 a $90 \%$ de cobertura no atual governo (sic.), se os planos da administração municipal atual forem implementados.

As precárias condições ambientais do município de Feira de Santana têm sido objeto de vários trabalhos de pesquisa e há entendimento de que se dispõe de legislação avançada, mas que não se efetiva na prática, de acordo com as necessidades locais. A esse respeito MÉLO (1997) afirma que o poder público temse envolvido em interesses econômicos e políticos discutíveis, dificultando que as 
ações, na área de meio ambiente, possam traduzir os princípios e normais legais existentes.

Em trabalhos, Anjos e Bastos (1968) citados por FRANCA ROCHA e NOLASCO (1998), no "Projeto Nascentes: um olhar sobre Feira de Santana" , o Plano Diretor do Centro Industrial Subaé, apresenta a distribuição do fluxo hídrico superficial e subterrâneo e suas relações com o impacto ecológico, o que indica que os gestores municipais, ao longo do tempo, teoricamente têm conhecimento das condições ambientais do município.

Nos últimos tempos, as lagoas do perímetro urbano de Feira de Santana vêm perdendo suas áreas verdes e dando lugar às construções irregulares de habitações. As lagoas mais prejudicadas pela ocupação desordenada são Lagoa Grande e Lagoa do Prato Raso, como se pode observar nas figuras que se seguem:

Figura 9 Foto da Lagoa Grande. Feira de Santana, 1997

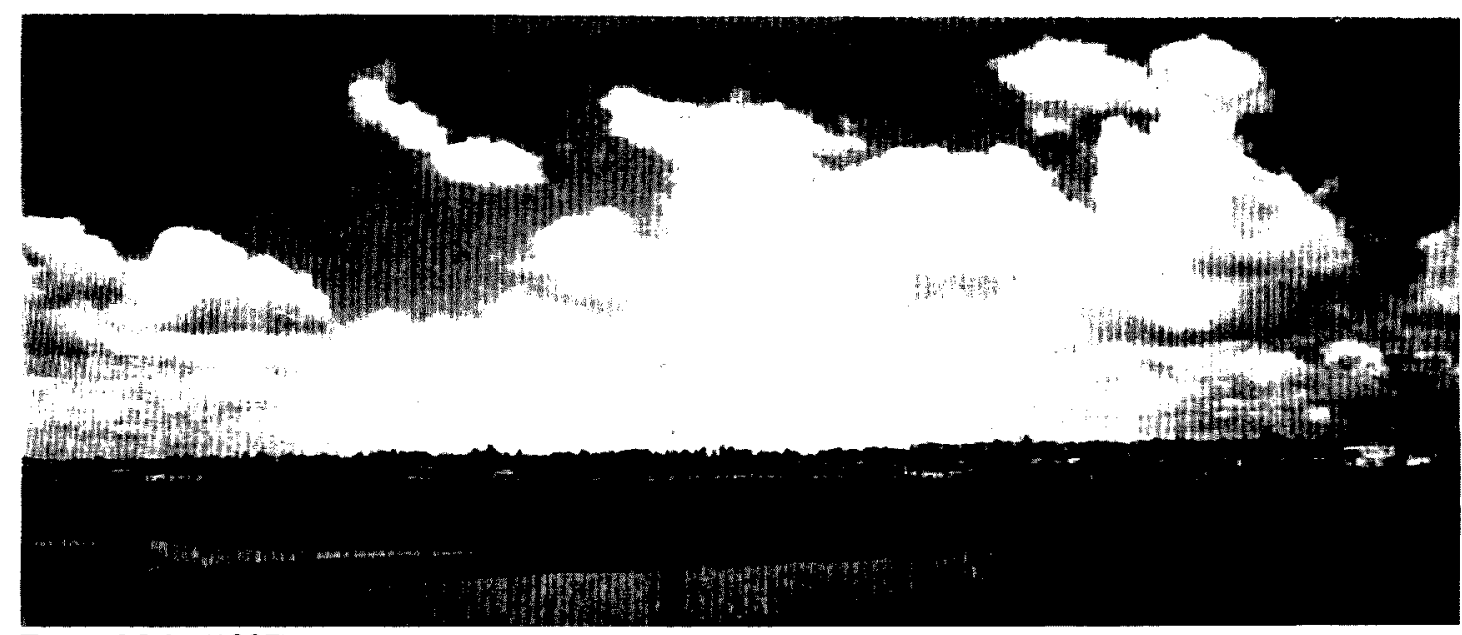

Fonte: Melo (1997)

No município de Feira de Santana, devido às características geográficas, a degradação ambiental é visível para as pessoas comuns. Mesmo nos registros dos Índices de Condições de Vida sobre habitação em que estas apresentam 97,1\% de materiais de construção duráveis, isto não significa que são apropriadas, como é o caso dessas construções na área da Lagoa do Prato Raso e da Lagoa Grande, no perímetro urbano de Feira de Santana: 
Figura 10 Foto da Lagoa do Prato Raso com Ocupação Irregular. Feira de Santana, 1997

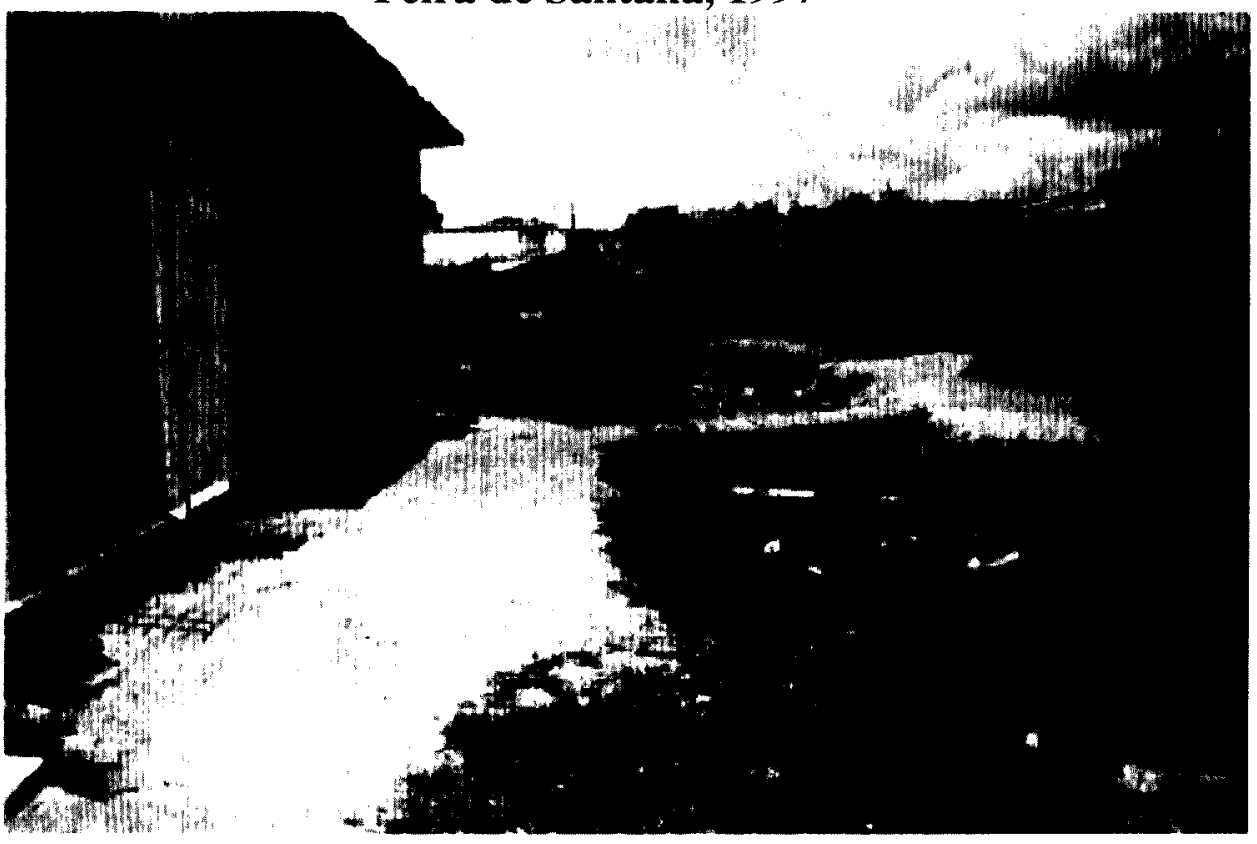

Fonte: Melo (1997)

Figura 11 Foto da Lagoa Grande com Ocupação Irregular. Feira de Santana, 1997

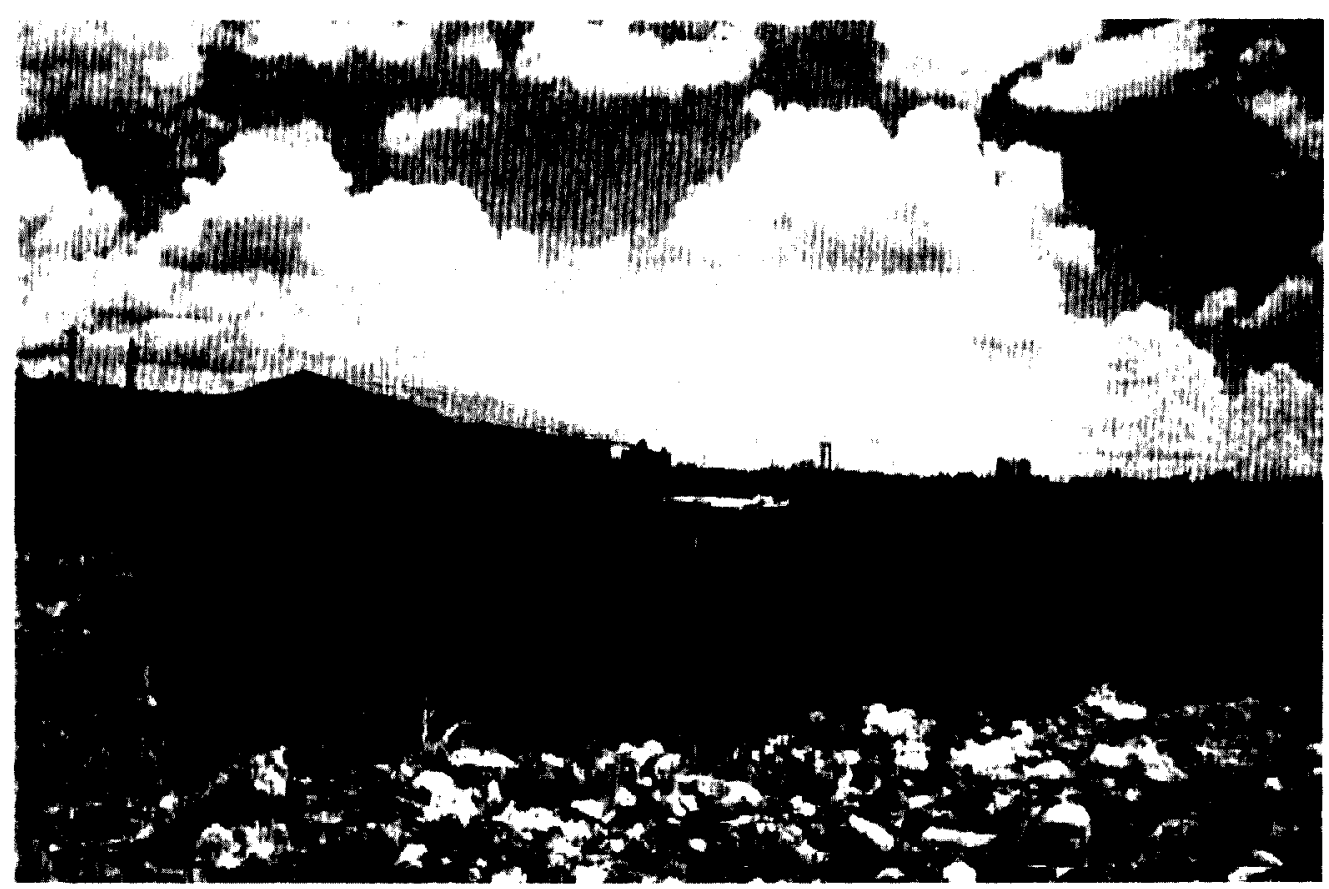

Fonte: Melo (1997) 
Dados da OPAS (1999) indicam que das 330.000 toneladas de lixo coletado diariamente na América Latina, $75 \%$ não têm destinação adequada. Diariamente, são lançados um mínimo de 82.500 toneladas de lixo no meio ambiente, servindo de alimento e criadouro de grande número de roedores e mosquitos, transmissores de diversas doenças.

Segundo dados da CEPAL, 39\% dos domicílios da América Latina e Caribe vivem em condições de pobreza, sendo $18 \%$ em condição de indigência. Das $37 \%$ das moradias inadequadas, apenas $21 \%$ podem ser melhoradas para se tornarem habitáveis. Essa situação implica em problemas de saúde pública, tais como doença de Chagas, Infecções Respiratórias Agudas (IRA), alergias e, inclusive, violência.

A violência, que se constitui num problema de saúde pública, especialmente pela altos índices de morbi-mortalidade dela decorrentes em que tem como causa as baixas condições de vida e com poucas opções de lazer.

Os estudos e intervenções de Chadwick cit. ROSEN (1994), representam, também, valiosos documentos, pois ele foi o autor da maior parte do primeiro relatório da Comissão de Saúde das Cidades, bem como das proposições administrativas e operacionais para a saúde na Inglaterra. A Comissão mostrava que superpopulação, pobreza, criminalidade, insalubridade e mortalidade alta conviviam entre si (ROSEN 1994).

A realidade brasileira depara-se, hoje, com índices de violência alarmantes, sobretudo nos centros urbanos, em conseqüência das super-populações, que se aglomeram na periferia dos grandes centros, nos últimos 50 anos. No Brasil, houve uma explosão demográfica entre os anos 50 e 70 , gerando pressão sobre a infraestrutura e orçamentos dos grandes centros urbanos, situação agravada pela recessão econômica dos anos 80 (CHESNAIS 1999).

O município de Feira de Santana, por sua disposição geográfica, é um centro migratório que não dispõe de recursos naturais adequados para o lazer, principalmente para a população de renda mais baixa, que não tem acesso aos locais privados, o que é retratada nas palavras de um secretário municipal:

"Feira não tem área verde, mas nós já conseguimos levantar mais de 300 mil metros de áreas doadas que não estão sendo utilizadas. Estamos fazendo um programa de revitalização das praças, os 
jardins, tem áreas públicas invadidas que estamos tentando reintegrá-las. Enfim, o programa é muito grande”. (Ent. n 4 )

Apesar de todas as desvantagens que se apresentam na vida da cidade grande, para onde as pessoas migram em busca de melhores condições de sobrevivência, o geógrafo e professor Milton Santos afirma que a cidade grande se configura como um espaço social significativo, um lugar onde todas as formas de organizações podem se instalar e conviver, um espaço onde os pobres podem subsistir (SANTOS M 1996).

No município de Feira de Santana, de acordo com o ICV de 1991, a renda insuficiente ultrapassa $50 \%$ da população (Quadro 11).

A contínua urbanização associada à expansão industrial transformou-se num problema crescente para a saúde pública e requer intervenções antes que se torne incontrolável (OPAS 1999).

Um dos principais documento da Rio 92, a Agenda 21 se constitui em uma metodologia aberta para a implementação do desenvolvimento sustentável. Suas diretrizes, metas e programas se orientam nas seguintes bases: preservação da biodiversidade, manejo dos recursos naturais, justiça econômica e social, cabendo a cada país instituir uma agenda nacional e agendas locais em estados e municípios, em uma iniciativa do poder público constituído, articulado à sociedade civil organizada (LOUREIRO et.al.1999).

No ano 2000, foi instituída a Agenda 21 do Município de Feira de Santana, resultante da iniciativa da Secretaria Executiva da Secretaria de Desenvolvimento Urbano e Meio Ambiente, sob a coordenação de um representante da igreja católica. Essa agenda 21 é referida, por um entrevistado, como um feito muito importante para o município:

"O código de meio ambiente de Feira de Santana é um dos mais avançados do Brasil"... ..."mas o nosso maior tento na área de meio ambiente, com reflexos na saúde, é a agenda 21 de Feira de Santana... ... Nossa agenda é nada mais nada menos que um órgão que dita as diretrizes de como conviver com o meio ambiente sem agredi-lo". (Ent. n 11). 
Dadas as características de concentração espacial de pessoas e atividades, SMOLKA (1996) refere-se à dificuldade ou inviabilidade de reparar os danos ambientais causados pelo processo de urbanização, ainda que visualize a possibilidade de atuar nas causas ou nos efeitos, embora o enfrentamento de reparo das questões ambientais seja extremamente difícil.

A fala de um secretário indica a carência de um mínimo de estruturação da administração municipal para enfrentamento dos problemas ambientais:

"Nós cuidamos imediatamente de fazer funcionar a CONDEMA Conselho Municipal de Meio Ambiente e providenciamos, também, a regulamentação do FUNDEMA, que é o Fundo Municipal de Meio Ambiente, é o órgão que recebe multas, doações, recebe participação do governo

federal e estadual... ...Quando não tinha esse órgão era impossível poder contar com essas verbas”. (Ent. n 11 ).

Pode-se inferir que, diante dos problemas ambientais apresentados pelo município a maior preocupação da Secretaria de Meio Ambiente é a estruturação da secretaria a fim de obter recursos para fiscalização do meio ambiente e, também, o financiamento das grandes obras de saneamento básico.

Diante da importância do meio ambiente na vida das pessoas, a sua conservação deve ser uma preocupação da sociedade em geral, como está pensado na Agenda 21: possibilitar o desenvolvimento sustentável, tornando as cidades mais humanas, para que as pessoas tenham melhor qualidade de vida, com renda adequada, saúde, educação, saneamento básico, moradia habitável, transporte, segurança e lazer.

Ainda que existam graves problemas de saneamento básico a serem resolvidos e dificuldades de financiamento para investimento nessa área, o poder de mobilização da sociedade civil organizada que integra a Comissão da Agenda 21 e a vontade demonstrada pelos secretários de melhorar a qualidade de vida em Feira de Santana, como se pode evidenciado nos discursos dos secretários $n^{\circ} 4$ e $n^{\circ} 11$, esta poderá ser 0 embrião gerador de um projeto de cidade saudável para Feira de Santana. 


\section{CONCLUSÕES}

As políticas públicas do município de Feira de Santana se efetivam por meio das ações das secretarias da administração municipal e são fundamentadas na Lei Orgânica elaborada com base na Constituição do Estado da Bahia e na Constituição Federal, e a qualidade de vida da população representa os reflexos das políticas públicas, ou da ausência delas, aliadas aos componentes de ordem cultural social e econômico.

Os resultados obtidos nessa análise permitem as seguintes conclusões:

- A Lei Orgânica do município, além de se configurar como um dos principais meios do município exercer sua autonomia, fixa as diretrizes para gestão e planejamento das ações do município;

- As secretarias municipais tentam promover investimentos de acordo com as diretrizes contidas na Lei Orgânica, com o objetivo de melhorar a qualidade da população;

- O município destina à área social $74 \%$ do orçamento total do município (considera-se área social as rubricas representadas no quadro $\mathrm{N}^{\circ} 5$ por educação; cultura, esporte e lazer; saúde; desenvolvimento urbano e social; desenvolvimento urbano e meio ambiente; desenvolvimento econômico e serviços públicos);

- Quanto à qualidade de vida da população do município de Feira de Santana, observa-se que, nas últimas décadas, houve evolução de todos os índices de desenvolvimento humano (educação, saúde e renda), com exceção dos índices relacionadas à renda que, após elevação na década de 1970, sofre queda a paratir da década de 1980.

- Durante o período estudado, observa-se um crescimento orçamentário no período de 1995 a 1997 da ordem de $68,43 \%$, havendo uma queda progressiva até o ano de 2001. O ano de 2002 ultrapassa o orçamento de 1997, com uma alta na ordem de $64,60 \%$. Nota-se que houve picos orçamentários em 1997 e 2002;

- Com relação à área de educação há queda dos índices de analfabetismo, embora ainda sejam considerados altos com relação ao Brasil. Esses índices se mantêm altos na Bahia como um todo, atingindo atualmente, a taxa de $20 \%$, que se encontra abaixo do índice para o Nordeste que é de $21,75 \%$ E O DO Brasil que é $11,4 \%$. 
- Há necessidade de uma ação conjunta dos vários setores da sociedade para enfrentar os problemas da educação, devido à situação de carência de grande parte das crianças e os problemas relacionados à desestruturação das famílias;

- A aplicação orçamentária, na área de educação, entre o ano de 1993 e 2002, oscilou entre 18 e $30 \%$ do orçamento total do município;

- Os índices educacionais para o município de Feira de Santana indicam a necessidade de investimentos mais significativos, que permitam melhorar os citados índices de qualidade da educação;

- O processo de descentralização da administração do sistema educacional no país tomou forma com as modificações ocorridas no Programa de Manutenção e Desenvolvimento do Ensino Fundamental (PMDE), com o Programa de Apoio Tecnológico (PAT) e o Programa Nacional de Alimentação Escolar (PNAE) com reflexo em Feira de Santana;

- Os programas do Ministério da Educação e Cultura (MEC) estão sendo, cada vez mais absorvidos pelo município, como forma de fortalecimento das ações na área de educação;

- A aprovação da Lei de Diretrizes e Bases da Educação Nacional (LDB) e a criação do Fundo de Manutenção e Desenvolvimento do Ensino Fundamental e de Valorização do Magistério (FUNDEF) fortalece o processo de municipalização da educação;

- Na área da saúde no município Feira de Santana se reproduz o atraso no processo de municipalização da saúde do Estado da Bahia;

- Não existe no orçamento de Feira de Santana, a exigência de um percentual mínimo destinado à área da saúde;

- A partir de 1998, há um crescimento no percentual de participação do orçamento total do município, que se supõe estar relacionado ao repasse do Piso de Atenção Básica (PAB);

- A previsão orçamentária para a saúde em 2002 apresenta significativa elevação, representando uma participação percentual da ordem de $34,2 \%$ do orçamento total. Essa participação ultrapassa o orçamento da educação e significa um crescimento percentual de quase $100 \%$ na área de saúde em relação ao ano anterior; 
- O aumento no orçamento da saúde para o município significa mais que um aumento de receita, uma mudança na estrutura do sistema municipal de saúde em que se prevê maior autonomia da secretaria de saúde na alocação dos recursos de saúde no município ao passar para a Municipalização Plena do Sistema de Saúde;

- A concepção das ações da Secretaria de Saúde parece centrada apenas na produtividade, sem apresentar resolutividade de problemas;

Em relação à área de meio ambiente, o município de Feira de Santana possui avanças no campo legislativo, com a aprovação da Lei Complementar $N^{\circ} 1.612 / 1992$ - Feira de Santana, que dispõe sobre o Código do Meio Ambiente e a proposta da Agenda 21 no ano 2000 ;

- Há deficiência na disponibilidade de esgotamento sanitário em relação à população do município;

- Nos últimos tempos, as lagoas do perímetro urbano de Feira de Santana vêm perdendo suas áreas verdes e dando lugar às construções irregulares de habitações;

- As Lagoas do Município estão contaminadas por esgotos domésticos provenientes das habitações irregulares na área das Lagoas e por moradias do entorno;

- As águas das Lagoas causam contaminações num raio de aproximadamente 100 $\mathrm{Km}$., chegando a atingir praias próximas à capital, Salvador;

- O município não dispõe de recursos próprios para investimento em saneamento básico, ficando sempre na dependência de recursos do Estado e da União;

- Os dados de ICV (Índice de Condições de Vida) sobre habitação de Feira de Santana indicam o nível de pobreza da população e da degradação do meio ambiente, o que prejudica a população mais carente e a população que possui melhor poder aquisitivo, através da contaminação dos mananciais e locais de lazer como Rios e o Mar;

- As precárias condições ambientais do município de Feira de Santana têm sido objeto de vários trabalhos de pesquisa e há entendimento de que se dispõe de legislação avançada, mas que não se efetiva na prática, de acordo com as necessidades locais. 


\section{REFERÊNCIAS}

Almeida ES, Castro CGJ, Vieira CAV. Distrito sanitário: concepção e organização. São Paulo: USP, 1998. 43p.

Almeida ES, Zioni F, Chioro A.Políticas públicas e organização do sistema de saúde antecedentes, reforma sanitária e o SUS. São Paulo; 1997.[ Apostila mimeografada - Faculdade de Saúde Pública - USP] .

Almeida ES. Contribuição à implantação do SUS: estudo do processo com a estratégia norma operacional básica 01. São Paulo; 1995. [ Tese de Livre Docência -Faculdade de Saúde Pública - USP].

Almeida KB. Mortalidade em menores de 5 anos no município de Feira de Santana - Bahia no período de 1998 - 2000. Feira de Santana; 2000. [Monografia de graduação em enfermagem - Departamento de Saúde da UEFS].

Andrade VRP. Cidadania: do direito aos direitos humanos. São Paulo: Acadêmica, 1993.

Araújo, EM. Configuração do espaço urbano de Feira de Santana - Ba. Sitientibus: Saúde Coletiva. 2001;1(1):9-16

Assis MA. As formas de produção dos serviços de saúde - o público e o privado. Ribeirão Preto; 1998. [Tese de Doutorado - Escola de Enfermagem de Ribeirão Preto e São Paulo - USP].

Assis MMA. A municipalização da saúde: intenção ou realidade? análise de uma experiência concreta. Feira de Santana : UEFS, 1996. 191p.

Bahia. Constituição do Estado da Bahia. Salvador: Assembléia Legislativa, 1989. $152 \mathrm{p}$. 
Bahia. Norma operacional básica do SUS: NOB/SUS 01/96. Salvador: Secretaria de Saúde, 1997.

Bahia. Plano estadual de saúde-1996-1999. Salvador: Secretaria de Saúde,1996.

Banco Mundial. Relatório sobre o desenvolvimento mundial: Investindo em saúde. Indicadores de desenvolvimento mundial. Brasília: Banco Mundial, 1995.

Barboni AR. Impacto de algumas causas básicas de morte na esperança de vida de residentes em Salvador e São Paulo - 1996. São Paulo, 2002.[Tese de Doutorado- Faculdade de Saúde Pública - USP] .

Bardin L. Análise de conteúdo. Trad. de LA Reto, A Pinheiro. Lisboa: edições 70, 1995.

Barreto ML, Carmo EH. Situação de saúde da população brasileira: tendências históricas, determinantes e implicações para as políticas de saúde. Informe Epidemiológico do SUS/FNS. Brasília ; 1994.Ano 3, n.3-4.

Barreto SAJ. Pobreza e desigualdade de renda no Brasil: evidências empíricas e uma análise sob a ótica da economia institucional. São Paulo, 2001.[Tese de Doutorado- Faculdade de Saúde Pública - USP].

Barros E. O controle social e o processo de democratização dos serviços de saúde: incentivo à participação popular e controle social no SUS. Brasília: Ministério da Saúde, 1994.

Barros RP, Henrique R, Mendonça R. Desigualdade e pobreza no Brasil: retrato de uma estabilidade inaceitável. Revista Brasileira de Ciências Sociais. 2000;15(42):132-142. 
Barros RP et al. Pobreza e política social. São Paulo: Fundação Konrad Adenaua., 2000 .

Batista Jr. PN. Mitos da “globalização”. Estudos Avançados. 1998;12(32):125-186.

Benevides MVM. Cidadania e democracia. Lua Nova: Revista de Cultura e Política $1994 ; 33: 5-16$.

Benevides MVM. A cidadania ativa: referendo, plebicito e iniciativa popular. $2^{\mathbf{a}}$ Edição. São Paulo: Ática, 1996.

Bobbio N. O Futuro da democracia. $7^{\text {a }}$ ed. São Paulo: Paz e Terra, 2000.

Brasil. Constituição da República Federativa do Brasil. $22^{\mathbf{a}}$ ed. São Paulo: Saraiva, 1999.

Brasil. Decreto lei 9.394, de 20 de dezembro de 1996. Estabelece as Diretrizes da Educação Nacional (LDB). Diário Oficial da República Federativa do Brasil, Brasília, 20 de dez. 1996.

Brasil. Decreto lei 9.424, de 24 de dezembro de 1996. Dispõe sobre o Fundo de Manutenção e Desenvolvimento do Ensino Fundamental e de Valorização do Magistério. Na forma prevista no artigo $60 \S 7^{\circ}$. Do Ato das Disposições Transitórias e dá outras providências. Diário Oficial da República Federativa do Brasil, Brasília, 24 de dez.1996.

Brasil. Lei complementar n. 101, de 4 de maio de 2000. Finanças públicas voltadas para a responsabilidade na gestão fiscal e dá outras providências. Diário Oficial da República Federativa do Brasil, Brasília, 2000.

Breilh J, Granda E. Investigação da saúde na sociedade. São Paulo: Instituto de Saúde SP-Abrasco, 1986. 
Breilh J. Pobreza urbana e la salud: uma mirada desde la epidemiologia crítica. Campinas: Abrasco, Anais do Congresso Brasileito de Epidemiologia; 1990.

Buss P. Rede de cidades saudáveis. Jornal do Conasems. Brasília, 1998.Agosto, edição especial: p. 8 .

Carvalho G. Saúde e eleições municipais. Canal Saúde. 2000; 1( 3):4

Carvalho GCM. O Financiamento público federal do Sistema Único de Saúde, 1988-2001. São Paulo; 2002 .[Tese de Doutorado - Faculdade de Saúde Pública USP].

Castellanos PL. Epidemiologia, saúde pública, situação de saúde e condições de vida: considerações conceituais. In: Barata, RB (org.). Condições de vida e situação de saúde. São Paulo: Abrasco, 1997.

Cerqueira EM. Práticas da vigilância epidemiológica em Feira de Santana. Feira de Santana; 2001.[Dissertação de Mestrado - Universidade Estadual de. Feira de Santana-Bahia].

Chauí M. Fantasias da terceira via. São Paulo: MAIS, 1999a.

Chauí M. A Reforma do Estado Brasileiro. Revista da Rede de Avaliação Institucional da Educação Superior. 1999b; 4:3(3-8).

Chesnais JC. A Violência no Brasil: causas e recomendações políticas para a sua prevenção. Ciência e Saúde Coletiva. 1999; 4 (1): 53 - 69.

Chioro A , Scaff, A. Saúde e cidadania: a implantação do Sistema Único de Saúde. Disponível em:<http:// www. Consaude.com.br/sushttm $>$. 
Cohn A. Descentralização, saúde e cidadania. Lua Nova: Revista de Cultura Política, 1994; 32:5-16.

Cohn A. Estado, políticas públicas e saúde. In. : Ciências Sociais e Saúde. Rio de Janeiro: HUCITEC / Abrasco, 1997. p.157 - 171.

Cohn A. Saúde e cidadania: análise de uma experiência de gestão local. In.: Eibenschutz C. Política de saúde: o público e o privado. Rio de Janeiro: FIOCRUZ, 1995.

Comisión Regional de Poder Local, Democracia y Desarrollo. “ Actores sociopoliticos y construccion democratica”. n.2. Honduras: ALFORJA,1995.

Comisión Regional de Poder Local, Democracia y Desarrollo. “ La construccion de poder y la valorizacion del espacio local, en las practicas de educacion popular", n.3. Honduras: ALFORJA, 1995

Cordeiro H. Sistema Único de Saúde. Rio de Janeiro: Editorial Abrasco, 1991.

Cordeiro V. A construção do SUS a partir do município. [Mimeo s.d.]

Costa NR , Ribeiro, JM. Política de saúde e inovação institucional: uma agenda para os anos 90. Rio de Janeiro: ENESP, 1996.

Costa NR. Políticas públicas, justiça distributiva e inovação: saúde e saneamento na agenda social. São Paulo: HUCITEC, 1998.

Cotta RMM, Mendes FF, Muniz JN. Descentralização das políticas públicas de saúde: do imaginário ao real. Viçosa: UFV, 1998.

Couttolenc BF , Zucchi PG. Gestão de recursos financeiros: saúde e cidadania para gestores municipais de saúde. São Paulo: IDS/USP/ITAU,1998. 
Crocker D. Qualidade de vida e desenvolvimento: o enfoque normativo de Sen e Nussbaum. Lua Nova :Revista de Cultura Política .1993; 31: 99-133

Dallari DA. Elementos de teoria geral do estado. $21^{\text {a }}$ ed. São Paulo: Saraiva, 2000.

Demo P. Participação é conquista. São Paulo: Cortez, 1988.

Dowbor L. Desafios da globalização. São Paulo: Vozes, 1998.

Eibenschutz C. (org.). Política de saúde: o público e o privado. Rio de Janeiro: Fiocruz, 1995.

Engels F. A situação da classe trabalhadora na Inglaterra. São Paulo: Porto Afrontamento, 1975

Escorel S. Exclusão social e saúde. Revista Saúde em Debate 1994;43:39-43.

Feira de Santana Lei $N^{\circ}$ 002. Dispõe sobre as Diretrizes Orçamentárias de Feira de Santana. Ano 2000. Prefeitura Municipal de Feira de Santana. Feira de Santana Bahia, 2000

Feira de Santana. Lei complementar $\mathrm{n}^{\circ}$ 1.612/92. Código de Meio Ambiente. Prefeitura Municipal de Feira de Santana. Feira de Santana - Bahia, 1992.

Feira de Santana. Lei $n^{\circ} .1 .629$ de 27 de dezembro de 1992 . Orçamento Anual. Secretaria Municipal do Planejamento - , 1992 Prefeitura Municipal de Feira de Santana. Feira de Santana - Bahia, 1992

Feira de Santana. Lei ${ }^{\circ}$. 1.725 de 27 de dezembro de 1993 . Orçamento Anual. Secretaria Municipal do Planejamento - , 1993 Prefeitura Municipal de Feira de Santana. Feira de Santana - Bahia, 1993 
Feira de Santana. Lei $n^{\circ}$. 1.782 de 27 de dezembro de1994. Orçamento Anual. Secretaria Municipal do Planejamento - , 1994 Prefeitura Municipal de Feira de Santana. Feira de Santana - Bahia, 1994

Feira de Santana. Lei $\mathrm{n}^{\circ}$. 1.832 de 27 de dezembro de 1995. Orçamento Anual. Secretaria Municipal do Planejamento - , 1995 Prefeitura Municipal de Feira de Santana. Feira de Santana - Bahia, 1995

Feira de Santana. Lei $\mathrm{n}^{\circ} .1 .886$ de 27 de dezembro de 1996 . Orçamento Anual. Secretaria Municipal do Planejamento - , 1996 Prefeitura Municipal de Feira de Santana. Feira de Santana - Bahia, 1996

Feira de Santana. Lei ${ }^{\circ}$. 1.968 de 27 de dezembro de 1997 . Orçamento Anual. Secretaria Municipal do Planejamento - , 1997 Prefeitura Municipal de Feira de Santana. Feira de Santana - Bahia, 1997

Feira de Santana. Lei ${ }^{\circ}$. 2.043 de 27 de dezembro de 1998 . Orçamento Anual. Secretaria Municipal do Planejamento - , 1998 Prefeitura Municipal de Feira de Santana. Feira de Santana - Bahia, 1998

Feira de Santana. Lei $n^{\circ} .2 .120$ de 27 de dezembro de 1999 . Orçamento Anual. Secretaria Municipal do Planejamento - , 1999 Prefeitura Municipal de Feira de Santana. Feira de Santana - Bahia, 1999

Feira de Santana. Lei $n^{\circ}$. 2.213 de 27 de dezembro de 2000 . Orçamento Anual. Secretaria Municipal do Planejamento - , 2000 Prefeitura Municipal de Feira de Santana. Feira de Santana - Bahia, 2000

Feira de Santana. Lei $n^{\circ} .2 .305$ de 27 de dezembro de 2001 . Orçamento Anual. Secretaria Municipal do Planejamento - , 2001 Prefeitura Municipal de Feira de Santana. Feira de Santana - Bahia, 2001 
Feira de Santana. Lei $\mathrm{n}^{\circ} 001$ de 27 de dezembro de 2000 . Dispõe sobre o Plano Pluri - Anual de Feira de Santana. Ano 2000. Prefeitura Municipal de Feira de Santana. Feira de Santana - Bahia, 2000

Feira de Santana. Lei $n^{\circ}$ 1.802/95. Modifica a Estrutura Organizacional da Prefeitura Municipal de Feira de Santana e dá outras Providências. Prefeitura Municipal de Feira de Santana, 1995.

Feira de Santana. Lei $\mathrm{n}^{\circ} 37$ de 1990. Dispõe sobre a Lei Orgânica do Município. Câmara de Vereadores de Feira de Santana 2000.

Fernandes RC. Privado porém público: o terceiro setor na América Latina. . Rio de Janeiro: Relumé-Dumará, 1994.

Fleury S. Estado sem cidadãos: seguridade social na América Latina. Rio de Janeiro: FIOCRUZ, 1994.

Franca Rocha WJS, Nolasco MC (eds). Projeto Nascentes: um olhar sobre Feira de Santana. Feira de Santana: UEFS, 1998. CD ROM

Freitas NB. Urbanização em Feira de Santana: influência da urbanização. Salvador, 1996. [Dissertação de Mestrado - Escola de Arquitetura - UFBA].

Freitas TS, Barbosa PJ, Amorim TNGF. Retórica, poder de decisão e grupos de pesquisa no nordeste do Brasil. Recife: Universidade Federal de Pernambuco, 1993.

Fundação SEADE. Índice paulista de responsabilidade social. São Paulo, 2001.

Furian S, Campos A, Cavalcante G, Mercês M G. Agenda 21: a Feira de Santana que queremos. Feira de Santana: DIGITCOM, 2000. 
Galvão MRA. Povoadores da região de Feira de Santana. Sitientibus. Ano I, $1982 ; 1(1): 25-31$.

Geddes P. Cidades em evolução. São Paulo: Papirus, 1994.

Gerschman Silvia. A democracia inconclusa. um estudo da reforma sanitária brasileira. Rio de Janeiro: FIOCRUZ, 1995.

Giacomoni J. Orçamento público. $10^{\mathrm{a}}$ ed. São Paulo: Atlas, 2001.

Giddens A. A terceira via. Trad. Maria Luiza A Borges. Rio de Janeiro e São Paulo: Record, 1999.

Giovanella L, Fleury S. Universalidade da atenção à saúde: acesso como categoria de análise.In: Eibenschutz, Catalina. Política de saúde: $\mathbf{O}$ público e o privado. Rio de Janeiro: FIOCRUZ.1995.

Gomez HA. Salud para todos en el Año 2000: implicaciones para la planificacion y administracion de los sistemas de salud. Colômbia: Universidad de Antioquia. Faculdade Nacional de Saúde Publica, 2000.

Gohn MG. Teoria dos Movimentos Sociais: paradigmas clássicos e contemporâneos. São Paulo: Edições Loyola; 1997.

Gramsci A Maquiavel, a política e o estado moderno. $8^{a}$ ed. Rio de Janeiro: Civilização Brasileira, 1991.

Green LW , Anderson LC. Community Health. $5^{\text {a }}$ ed. Toronto: Times Mirror, 1986.

Gruppi L. Tudo começou com Maquiavel: as concepções de estado em Marx, Engels, Lenin e Gramsci. 14 a ed. Porto Alegre: L\&PM, 1996. 
Guimarães, EA. (Cood.). Relatório sobre o desenvolvimento humano no Brasil, 1996. Brasília: PNUD/IPEA, 1996.

Habermas J. A nova transparência: a crise do estado de bem - estar social e o esgotamento das energias utópicas. Novos Estudos. 1987; 18:103-114.

Hoffmann R. Distribuição de renda, medidas de desigualdade e pobreza. São Paulo: Edusp, 1998.

Iannome RA . A revolução industrial. 7 ed. São Paulo: Moderna, 1992.

[IBGE] Fundação IBGE.Indicadores sociais mínimos. Pesquisa nacional por amostra de domicilios. Rio de Janeiro:IBGE 2000.

[IBGE] Fundação IBGE. Contagem da População: 1996. Rio de Janeiro; 1997.

Jacobi P. Atores sociais e estado: movimentos reivindicatórios urbanos e estado: dimensões da ação coletiva e efeitos políticos Institucionais no Brasil. Espaço e Debates 1989;26:10-21.

Lalonde M. A new perspective on the health of canadians: a work peper. Otawa: Minister of Supply and Services, 1974, 76p.

Lavalle AG. A humildade do universal: Habermas no Espelho de Rawls. Lua Nova: Revista de Cultura Política .1997; 42: 145-182.

Lawrence, G. Case Studies on Private-Public-Communit Partnership in Seatle, WA USA. In: Seminário internacional de sociedade e reforma do Estado MARE,1998. São Paulo;1998.

Leavell HE, Clark EG. Medicina preventiva. São Paulo: McGraw ,1978. 
Laurell AC. La salud-enfermidad como processo social. Cadernos Médico Sociales 1982;19:7-20.

Lee J. Cidade saudável. Porto Alegre RS, 1994. Disponível emURL: http:// orion.ufrgs.Br/daos/CIDSAUD.HTM.

Loureiro CF. Limites e possibilidades para a Agenda 21 local. Políticas Ambientais. Brasília, 1998.

Luz MT. A conferencias nacionais de saúde e as políticas de Saúde da década de 80 Saúde e sociedade no Brasil. Rio de janeiro: Abrasco, 1994.

Majone G. Do estado positivo ao estado regulador: causas e consequiências de mudança no modo de governança. Revista do Serviço Público. 1999;50(1):

Martins ACP e ASSIS MMA. Serviços de Saúde (Públicas e Privados) de Feira de Santana - BA Feira de Santana, 2002 21p (digitado)

Maluf S. Teoria geral do estado. São Paulo: Saraiva, 1999.

Melo CMM. et. al. As organizações sociais como executora das ações públicas não estatais de Saúde. São Paulo, 1998. [Monografia de graduação da Faculdade de Administração Pública - USP].

Melo, ACS. A legislação ambiental brasileira na preservação das lagoas localizadas no perímetro urbano de Feira de Santana: estudo de caso. Feira de Santana, 1997 [ Monografia de especialista em Direito Sanitário - UEFS].

Mendes EV (org.) Distrito sanitário: o processo social de mudança do Sistema Único de Saúde. São Paulo - Rio de Janeiro: HUCUTEC / ABRASCO, 1993. 
Mendes EV. Uma agenda para a saúde. São Paulo: HUCITEC, 1996.

Mendes R. Cidades saudáveis no Brasil e os Progressos Participativos: os casos de Jundiaí e Maceió. São Paulo; 2000. [Tese de Doutorado - Faculdade de Saúde Pública - USP].

Merhy EE. A saúde pública como política: um estudo de formuladores de políticas. São Paulo: HUCITE, 1992.

Minayo MCS, Hartz ZMA, Buss PM. Qualidade de vida e saúde: um debate necessário. Ciência e Saúde Coletiva. 2000; 5(1):07-18.

Minayo MCS. O desafio do conhecimento: pesquisa qualitativa e saúde. $7^{\text {aed. São }}$ Paulo Rio de Janeiro: Hucitec - Abrasco, 2000.

[MARE] Ministério da Administração Federal e Reforma do Estado (MARE). Plano Diretor da Reforma do Aparelho do Estado. Plano aprovado pela Câmara de Reforma do Estado da Presidência da República. Brasília: Imprensa Nacional, 1995.

[MEC] Ministério de Educação e Cultura. Programa de apoio aos secretários municipais de educação (PRASEM II): marcos legais. Brasília, 1999.

[MS] Ministério da Saúde. IDB 98 Brasil. Rede Interagencial de Informações para a Saúde: RIPSA.1998.

[MS] Ministério da Saúde. Promoção promoção de saúde: Brasília: Secretária de Políticas de Saúde. Adelaide, Sundsvall e Santa Fé de Bogotá: Tradução de Luiz Eduardo Fonseca - Brasília, 1996.

[MS] Ministério da Saúde. Promoção promoção de saúde: Brasília: Secretária de Políticas de Saúde. Adelaide, Sundsvall, Santa Fé de Bogotá, Declaração de Jacarta, Rede de Megapaíses e Declaração do México: - Brasília, 2001. 
Moraes A . Direito Constitucional. $7^{\text {a }}$ ed. São Paulo: Atlas, 2000.

Moraes LRS. Política e Regulamentação do Saneamento Básico na Bahia: Situação atual e necessidade de arcabouço jurídico-institucional. Resumo dos Trabalhos Técnicos $-21^{\circ}$ Cong. Bras. de Engenharia Sanitária. 16 a 21 de setembro. João Pessoa, 2001.

Motta FCP e Pereira, LCB. Introdução à organização burocrática. $6^{\mathbf{a}}$ ed. São Paulo: Brasiliense, 1988.

Motta PR. Gestão contemporânea: a ciência e a arte de ser dirigente. $9^{\mathrm{a}}$ ed. Rio de Janeiro e São Paulo: Record, 1998.

Moura D. Saúde não se dá: conquista-se. São Paulo : HUCITEC, 1989.

Noronha JCE , Leucovitz E. AIS - SUDS - SUS: o caminhos do direito à saúde: saúde e sociedade no Brasil. Org. Guimarães, R. e TAVARES, R. Rio de Janeiro: Abrasco / IMS / UERJ/ RELUME - DUMARÁ, 1994.

Off $\mathrm{C}$. The present historical transition and some basic design options for societal institutions. Institute of Social Sciences Humboldt University, Berlim. In Seminário Internacional de Sociedade e a reforma do Estado. São Paulo: MARE, 1998.

Oliveira FA. Evolução, determinantes e dinâmica do gasto social no Brasil: 1980/1996 - Texto para discussão No 649 - IPEA, Brasília, 1999.

Oliveira JB. Renda percapita, desigualdades de renda e educação, e participação política no Brasil. Texto para discussão No 827. IPEA. Rio de Janeiro e Brasília: IPEA, 2001. 
[OPAS/OMS] Extensão de cobertura dos serviços de saúde mediante uso das estratégias de assistência primária e participação da comunidade. IV Reunião Especial de Ministros da Saúde da América. Washington 26 e 27 de set.1977.

[OMS] Organização Mundial de Saúde e Fundo das Nações Unidas para Infância (UNICEF). Relatório da Conferência Internacional sobre Cuidados Primários de Saúde. Alma-Ata, URSS, 6-12 de setembro 1978. Brasil, 1979.

[OMS] Organização Mundial de Saúde. Renovação de saúde para todos 2025. Brasília: Ministério da Saúde, 1995.

Ortiz AR. Et. al. A Proposta da reforma do Aparelho do Estado e suas Possíveis Implicações no SUS. São Paulo, 1996. [Monografia apresentado na disciplina Políticas de Saúde e Sociologia da Administração Pública. FSP/USP].

Pacheco T. O Brasil depois da Rio mais dez. Jornal A Tarde. Salvador,Ba p. 4. 27 out. 2002

Paim, JS. A democratização da saúde e o SUDS: o caso da Bahia. Saúde em Debate, $1988 ; 21: 39-44$.

Pastore J. Enfrentando o atraso: qualidade é o próximo passo. Revista Veja .2002; $\left(n^{\circ}\right.$ esp.): 54-55.

Pereira JM. Finanças públicas. São Paulo: Atlas, 1999.

Pereira LCB. A crise econômica e reforma do estado no Brasil: para uma nova interpretação da América Latina. São Paulo: Editora 34, 1996.

Pereira LCB. Da Administração pública burocrática à gerencial. Revista do Serviço Público. Ano 47, 1996;120. 
Pereira LCB Fantasias da terceira via. São Paulo: MAIS ( A Folha), 1999

Pereira M. Epidemiologia: teoria e prática. Rio de Janeiro: Guanabara Koogan, 1995.

Pinto A Distribuição de renda na América Latina e desenvolvimento. Rio de Janeiro: Zahar Editores, 1976.

[PNUD/IPEA] Desenvolvimento humano e condições de vida: indicadores brasileiros. Brasília: PNUD, 1998.

[PNUD/IPEA] Atlas do desenvolvimento humano no Brasil: Guia de uso do CDROM. Brasília: PNUD, 1998.

Ramos L, Vieira ML. Desigualdade de Rendimentos no Brasil nas décadas de 80 e 90: evolução e principais determinantes. Texto para discussão $\mathbf{N}^{\circ}$ 803. IPEA. Rio de Janeiro e Brasília: IPEA, 2001.

Richardson, RJ. Pesquisa social: métodos e técnicas. $2^{\text {a }}$ ed. São Paulo: Atlas, 1989.

Rosen, G. Uma história da saúde pública. São Paulo: UNESP/HUCITEC/Abrasco, 1994.

Rouquayrol Z. Epidemiologia \& saúde. Rio de Janeiro: Medsi,1994.

Rufino Neto A .Qualidade de vida: compromisso histórica da epidemiologia. . Belo Horizonte: Coopmed / Abrasco, 1994.

Sanches Filho AO. Novas demandas sociais: os espaços de construção da cidadania e o Ministério Público Estadual da Bahia. 1998. Salvador [Dissertação de Mestrado - Mestrado em Administração - Universidade Federal da Bahia]. 
Santana JSS. Saúde-doença no cotidiano de meninos e meninas de rua: ampliando o agir da enfermagem. 1998. Rio de Janeiro [Tese de Doutorado Escola de Enfermagem Anna Néri - Universidade Federal do Rio de Janeiro].

Santos BS. Pela mão de Alice: O social e o político na pós-modernidade. $5^{\text {a }}$ ed. São Paulo: Cortez, 1999.

Santos BS. A reinvenção solidária e participação do estado. In: Seminário Internacional de Sociedade e reforma do Estado - MARE,1998. São Paulo;1998.

Santos N. A natureza do espaço, São Paulo: Hucitec, 1996.

São Paulo. Tribunal de Contas do estado de São Paulo. Financiamento das ações e serviços de saúde. [Manual Básico. Instrução № 1 / 2001.] 2001.

Saviani DA. LDB e o Plano Nacional de Educação: por uma outra política educacional. Campinas: Editora Autores Associados, 1998.

Sen A. Desenvolvimento como liberdade. São Paulo: Companhia das Letras, 2002.

Sen A, and Nussbaum M. The quality of life: a study prepared for world institute for developnent economics research (wider) of the Nations University. Oxford: Clarendon Press, 1985.

[SESAB] Secretaria de Saúde. Sistema de Informação de Mortalidade - SIM. Salvador, 2000.

Silva AJM. Terra de sã natureza: a construção do ideal de cidade saudável em Feira de Santana (1833-1920). Feira de Santana, 1997. [Monografia apresentada ao Curso de Especialização em História - UEFS.].

Silva, JA. Curso de direito constitucional positivo. $13^{a}$ ed. São Paulo: Helvética, 1996. 
Silva, SF. A Reforma do Aparelho de Estado e sua Interface com a Saúde. São Paulo, 1997. [Monografia apresentado na disciplina Políticas de Saúde e Sociologia da Administração Pública. FSP/USP].

Smolka MO. Meio Ambiente e estrutura infra- urbana in: População, meio ambiente e desenvolvimento: verdades e contradições. $2^{\mathrm{a}}$ ed. Org. George Martin.Campinas: UNICAMP, 1996.

Souza C, Carvalho IMM. Reforma do estado, Descentralização e Desigualdade. Lua Nova: Revista de Cultura e política. 1999; 48:187-212.

Spínola ND , Spínola CA. Diagnóstico sócio econômico de Feira de Santana. Salvador: Secretaria da Indústria, Comércio e Mineração, 1998.

Szwarcwald CL, Leal MC, Castilho EA, Andrade CLT . Mortalidade infantil no Brasil: Belíndia ou Bulgária? Cad. Saúde Pública. 1997;13(6):503-516.

Teixeira AS. Educação é um direito. São Paulo. Companhia Editorial Nacional, 1968.

Teixeira AS. O ensino no estado da Bahia. Salvador. Ed. Fac-símile, 2001.

Teixeira, CF. Os Municipalização da Saúde caminhos do labirinto. Revista Saúde em Debate. 1991;33:27-33.

Teixeira EC. Sociedade civil e participação cidadã. Salvador: UFBA, 2000.

Testa M. Pensar em saúde. Porto Alegre: Artes Médica - Abrasco, 1992.

Thopson F I. Health policy and the Bureaucracy: polics and implementacion. Massachusetts and Ingland: The Mit Press, 1981. 
Trivinos AS. Introdução à pesquisa em ciências sociais: pesquisa qualitativa em educação. São Paulo: Atlas, 1992.

Tolosa. Reportagem Especial: o desafio da periferia. Rev. Veja 2001; Ed 1684.

Wallerstein N. Powerlwssness, empowerment and health: implications for health Promotion Programs. American Journal of Helth Promotion. 1992; 6( 3)

Westphal, MF. Municípios saudáveis: aspectos conceituais. Saúde e sociedade. 1997;6(2):9-18

Westphal, MF. O movimento cidades/municípios saudáveis: um compromisso com a qualidade de vida. Ciência e Saúde Coletiva; 2000; 5(1):39.

Westphal MF , Almeida ES (org.). Gestão de Serviços de Saúde. São Paulo: Edusp, 2001 


\section{ANEXOS}

\section{Anexo 1 - Termo De Consentimento Livre E Esclarecido}

Aceito participar da pesquisa "Políticas Públicas e Qualidade de Vida no Município de Feira de Santana”, da pesquisadora Creuza Maria Brito Queiroz, aluna Curso de Doutorado da Faculdade de Saúde Pública da Universidade de São Paulo.

Fui informado(a) que a pesquisa pretende analisar as políticas públicas do município de Feira de Santana relacionadas com o perfil de qualidade de vida da população expressa no Índice de Desenvolvimento Humano. Como participante da pesquisa serei entrevistado uma ou mais vezes pelo pesquisador na gabinete do secretário municipal ou outro local de sua preferência, com duração máxima de uma hora e com o auxílio do gravador, sendo essa entrevista marcada com antecedência.

Sei que tenho liberdade de recusar a participar da pesquisa e de deixá-la a qualquer momento.

Fui também esclarecido(a) que meu nome não será divulgado nos resultados da pesquisa e que as informações que darei serão utilizadas somente para os propósitos da pesquisa.

Data -

Assinatura do(a) participante da pesquisa

Telefone de contato da UEFS: $(0 \times x 75) 224.8089 / 8095$ 


\section{Anexo 2 - Roteiro de Entrevista}

Roteiro da Entrevista com os secretários municipais

Fale sobre as atividades desenvolvidas por esta secretaria

Existe um plano de atividades para esta secretaria?

Se existe, como foi formulado?

- Há participação da sociedade civil organizada, em algum momento?

- É utilizado algum documento oficial do município para embasar esse planejamento (exemplo: (Lei Orgânica do Município, Lei Orçamentária Anual ou outras) 


\section{Anexo 3 - Declaração de Alma-Ata}

A Conferência Internacional sobre Cuidados Primários de Saúde, reunida em Alma-Ata aos doze dias do mês de setembro de mil novecentos e setenta e oito, expressando a necessidade de ação urgente de todos os governos, de todos os que trabalham nos campos da saúde e do desenvolvimento e da comunidade mundial, para proteger e promover a saúde de todos os povos do mundo, formula a seguinte declaração:

A Conferência reafirma enfaticamente que a saúde - estado de completo bem-estar físico, mental e social, e não simplesmente a ausência de doença ou enfermidade - é um direito humano fundamental, e que a consecução do mais alto nível possível de saúde é a mais importante meta social mundial, cuja realização requer a ação de muitos outros setores sociais e econômicos, além do setor saúde.

A chocante desigualdade existente no estado de saúde dos povos, particularmente entre os países desenvolvidos e em desenvolvimento, assim como dentro dos países, é política, social e economicamente inaceitável, e constitui por isso objeto de preocupação comum de todos os países.

\section{III}

O desenvolvimento econômico e social baseado numa ordem econômica internacional é de importância fundamental para a mais plena realização da meta de saúde para todos e paraa a redução da lacuna entre o estado de saúde dos países em desenvolvimento e desenvolvidos. A promoção e proteção da saúde dos povos é essencial para o contínuo desenvolvimento econômico e social e contribui com a qualidade de vida e para a paz mundial. 
É direito e dever dos povos participar individual e coletivamente no planejamento e na execução de seus cuidados de saúde.

Os governos têm pela saúde de seus povos uma responsabilidade que só pode ser realizada mediante adequadas medidas sanitárias e sociais. Uma das principais metas dos governos, das organizações internacionais, e toda a comunidade mundial na próxima década deve ser a de que todos os povos do mundo, até o ano 2000, atinjam um nível de saúde que lhes permita levar uma vida social e economicamente produtiva. Os cuidados primários de saúde constituem a chave para que essa meta seja atingida, como parte do desenvolvimento, no espírito da justiça social.

\section{VII}

Os cuidados primários de saúde:

1. refletem, e a partir deles evoluem, as condições econômicas e as características sócioculturais e políticas do país e de suas comunidades, e se baseiam na aplicação dos resultados relevantes da pesquisa social, biomédica e de serviços de saúde e da experiência em saúde pública;

2. têm em vista os principais problemas de saúde da comunidade, proporcionando serviços de promoção, prevenção, cura e reabilitação conforme as necessidades.

3. Incluem pelo menos: educação no tocante a problemas prevalecentes de saúde e aos métodos para sua prevenção e controle, promoção da distribuição de alimentos e da nutrição apropriada, previsão adequada de água de boa qualidade e saneamento básico, cuidados de saúde materno-infantil, inclusive planejamento familiar, imunização contra as principais doenças infecciosas, prevenção e controle de doenças localmente endêmicas, tratamento apropriado de doenças e lesões comuns e fornecimento de medicamentos essenciais; 
4. Envolvem, além do setor saúde, todos os setores e aspectos correlatos do desenvolvimento nacional e comunitário, mormente a agricultura, a pecuária, a produção de alimentos, a indústria, a educação, a habitação, as obras públicas, as comunidades e outros setores e requerem os esforços coordenados de todos esses setores;

5. Requerem e promovem a máxima autoconfiança e participação comunitária e individual no planejamento, organização, operação e controle dos cuidados primários de saúde, fazendo o mais pleno uso possível dos recursos disponíveis, locais, nacionais e outros, e para esse fïm desenvolvem, através da educação apropriada, a capacidade de participação das comunidades;

6. Devem ser apoiadas por sistemas de referência integrados, funcionais e mutuamente amparados, levando à progressiva melhoria dos cuidados gerais de saúde para todos e dando prioridade aos que têm mais necessidades.;

7. Baseiam-se, aos níveis local e de encaminhamento, nos que trabalham no campo da saúde, inclusive médicos, enfermeiras e parteiras, auxiliares e agentes comunitários, conforme seja aplicável, assim como em praticantes tradicionais, conforme seja necessário, convenientemente treinados para trabalhar, social e tecnicamente, ao lado da equipe de saúde e para responder às necessidades expressas de saúde da comunidade.

\section{VIII}

Todos os governos devem formular, estratégias e planos nacionais de ação, para lançar e sustentar os cuidados primários de saúde em coordenação com outros setores. Para esse fim, será necessário agir com vontade política, mobilizar ao recursos do país e utilizar racionalmente os recursos externos disponíveis.

\section{IX}

Todos os países devem cooperar, num espírito de comunidade e serviço, para assegurar os cuidados primários de saúde a todos os povos, uma vez que a consecução da saúde do povo de qualquer país interessa e beneficia diretamente todos os outros países. Nesse 
contexto, o relatório conjunto da OMS/UNICEF sobre cuidados primários de saúde constitui sólida base para o aprimoramento adicional e a operação dos cuidados primários de saúde em todo o território.

Poder-se-á atingir um nível aceitável de saúde para todos os povos do mundo até o ano 2000 mediante o melhor e o mais completo uso dos recursos mundiais, dos quais uma parte considerável é atualmente gasta em armamento e conflitos militares. Uma política legítima de independência, paz, distensão e desarmamento pode e deve liberar recursos adicionais, que podem ser destinados a fins pacíficos, e em particular à aceleração do desenvolvimento social e econômico, do qual os cuidados primários de saúde, como parte essencial, devem receber sua parcela apropriada.

A Conferência Internacional sobre Cuidados Primários de Saúde concita à ação internacional e nacional urgente e eficaz, para que os cuidados primários de saúde sejam desenvolvidos e aplicados em todo o mundo, e particularmente nos países em desenvolvimento, num espírito de cooperação técnica e em consonância com a nova ordem econômica internacional. Exorta os governos, a OMS e a UNICEF, assim como outras organizações internacionais, bem como entidades multilaterais e bilaterais, organizações não governamentais, agências financeiras, todos os que trabalham no campo da saúde e toda a comunidade mundial a apoiar um compromisso nacional e internacional para os cuidados primários de saúde e a canalizar maior volume de apoio técnico e financeiro para esse fim particularmente nos países em desenvolvimento. A Conferência concita todos eles a colaborar para que os cuidados primários de saúde sejam introduzidos, desenvolvidos e mantidos, de acordo com a letra e espírito desta Declaração.

Conferência Internacional cobre Cuidados Primários de Saúde. Alma-Ata, URSS, 6-12 de setembro de 1988. OMS/UNICEF. Brasil 1979. Anexo III - Declaração de Alma-Ata 